\title{
LÍMITES A LA LIBERTAD DE EXPRESIÓN EN ESTADOS UNIDOS. LA LUCHA CONTRA LAS "PUBLICACIONES INMORALES" (SIGLOS XIX Y XX)
}

\section{RESTRICTIONS ON THE LIBERTY OF PRESS IN UNITED STATES OF AMERICA. THE FIGHT AGAINST IMMORAL PUBLICATIONS (XIX ${ }^{\text {th }}-\mathbf{X X}^{\text {th }}$ CENTURIES)}

\author{
Ignacio Fernández Sarasola \\ Universidad de Oviedo
}

\begin{abstract}
SUMARIO: I. LAS PRIMERAS PUBLICACIONES ACUSADAS DE INMORALIDAD.- II. LAS DIME NOVELS COMO PARADIGMA DE LITERATURA INMORAL.- II. LAS SOCIEDADES DE REPRESIÓN DEL VICIO Y LA CAMPAÑA MORAL CONTRA LA LITERATURA INMORAL.- IV. LA LEGISLACIÓN ANTIOBSCENIDAD COMO RESPUESTA A LA PRESIÓN SOCIAL.- V. NUEVAS FORMAS DE LITERATURA Y LA HERENCIA DE LA INMORALIDAD: PULP MAGAZINES Y COMIC BOOKS.- VI. CAMPAÑA SOCIAL Y MEDIDAS LEGISLATIVAS CONTRA LAS PULP MAGAZINES.- VII. LAS MEDIDAS LEGISLATIVAS CONTRA LOS CÓMICS.- VIII. LA CORRECCIÓN JURISPRUDENCIAL (I): LOS LÍMITES A LA LEGISLACIÓN CONTRA LAS PUBLICACIONES ESCABROSAS.- IX. LA CORRECCIÓN JURISPRUDENCIAL (II): LOS LÍMITES A LA LEGISLACIÓN CONTRA LAS PUBLICACIONES OBSCENAS
\end{abstract}

Resumen: Las publicaciones inmorales resultaron prohibidas prácticamente desde el momento mismo del nacimiento de los Estados Unidos de Norteamérica. En muy buena medida, debido a la actividad de las Sociedades para la prevención del vicio, que fueron muy influyentes entre el siglo XIX y los primeros veinte años del XX. Algunas de las publicaciones más perseguida fueron las dime novels (siglo XIX), las pulp magazines (19001940) y los comic books (1940-1956). Los críticos acusaron a tales revistas de ser violentas y obscenas, solicitando su ilegalización. Las primeras leyes a este respecto se refirieron al servicio de Correos, ya que aquellas publicaciones utilizaban la vía postal para su distribución. Sin embargo, posteriormente algunos Estados y municipios comenzaron a aprobar Códigos Penales y leyes y ordenanzas especiales que incluian penas por la venta de literatura inmoral. Ello no obstante, el Tribunal Supremo acabó declarando muchas de esas normas inconstitucionales por violentar las enmiendas primera y cuarta de la Constitución federal.

Abstract: Immoral publications were forbidden almost at the beginning of US's birth. Mainly due to the Vice Societies' activity, which were very influential between the XIXth century and the first twenty years of the XXth century. Some of the most persecuted readings were the dime novels (XIXth century), pulp magazines (1900-1940) and comic books (1940-1956). Critics charged that these magazines were violent and obscene and asked for acts 
forbidding their selling. The first acts were relating Post Office regulations, as those magazines used to be posted, but later some States and Cities passed Criminal Codes and special laws and orders which included penalties for selling immoral readings. Nevertheless, Supreme Court declared many of these rules to be unconstitutional as they collide with First and Fifth Amendments.

Palabras clave: publicaciones inmorales, obscenidad, libertad de imprenta, proceso legal, Tribunal Supremo, dime novels, pulp magazines, cómics

Keywords: immoral publications, obscenity, liberty of the press, due process of law, Supreme Court, dime novels, pulp magazines, comic books

\section{LAS PRIMERAS PUBLICACIONES ACUSADAS DE INMORALIDAD}

La acusación de que ciertas publicaciones incurrian en indecencia e inmoralidad $\mathrm{y}$ que, por tanto, eran perniciosas para los lectores, prácticamente acompañó al nacimiento de los Estados Unidos. Sin embargo, cobró especial ímpetu a partir de 1830, momento en el que comenzaron a surgir los primeros periódicos populares -alejados de los antaño panfletos partidistas- con New York Sun (1833), Evening Transcript (1835) y New York Herald (1835). Tales diarios, en especial el último, atraían al público no sólo con su bajo precio (inferior a los seis peniques que costaba la prensa política) sino también por unas portadas en las que se premiaban los acontecimientos más escabrosos. Los intelectuales y editores de prensa "seria" (es decir, politica) no tardaron en tildar a la competencia de panfletos sucios que promovian el vicio y contaminaban la mente de la juventud. Unas acusaciones que darían inicio a la "Guerra Moral" que comenzó a resultar patente a partir de $1840^{1}$.

A pesar de estas críticas, el periodismo sensacionalista no dejó de crecer. Dos personajes extremadamente influyentes asi lo posibilitarian: Joseph Pulitzer y William Randoph Hearst. El primero, a través del PostDispacth de Saint Louis (1878) y sobre todo el periódico neoyorkino World (1883) fomentó una prensa plagada de noticias sobre corrupción y sexo que sería emulada por su estrambótico rival, Hearst con The San Francisco Examiner (1887) y The New York Journal (1895).

Tales publicaciones levantarian las suspicacias de intelectuales y clérigos, avalados por estudios científicos que pretendian demostrar cómo las lecturas influían en el deterioro psicológico de los estadounidenses. Así George M. Beard (1839-1883), neurólogo miembro de la Academia de Medicina de New York, había advertido del incremento de casos de neurosis debido, entre otros factores, a la lectura de periódicos que entrañaba una sobrecarga informativa ${ }^{2}$. Resultaba sencillo concluir que,

1 Starker, Steven: Evil Influences. Crusades against the Mass Media, Transaction Publishers, New Jersey, 1991, pp. 44-45.

2 Beard, George Miller: American Nervousness. Its Causes and Consequences, G. P. Putnam's Sons, New York, 1881, pp. VI, 96, 99 y 138. 
cuanto más escabrosos resultasen, más incidencia tendría en la psique de los lectores.

Pero los periódicos no eran los únicos que supuestamente pervertían las mentes de los ciudadanos. También lo hacían las novelas, desde sus primeros pasos en territorio estadounidense. En 1740 veía la luz en Londres Pamela: or, Virtue Rewarded, escrita por Samuel Richardson. Apenas dos años más tarde, la obra figuraba en la lista de libros prohibidos por la Iglesia de Roma, coincidiendo con la fecha en la que Benjamin Franklin decidió reimprimirla en Philadelphia, convirtiéndose en la primera novela publicada en Estados Unidos. La obra, contada con forma epistolar, narraba la vida de una sirvienta de quince años, Pamela Andrews, que se enfrentaba al acoso sexual, e incluso intento de violación, por parte de su patrón.

No tardaron en surgir los detractores de la obra. En 1741 se publicaria un panfleto titulado Pamela Censored: In A Letter To The Editor en el que se acusaba al libro de desvirtuar la mente de los jóvenes bajo la apariencia de cultivar la moralidad y la virtud ${ }^{3}$. En Inglaterra, donde habia nacido la obra, Samuel Johnson llegó a advertir que incluir personajes moralmente ambiguos en narraciones de factura realista podía provocar la connivencia del lector, dando lugar a una relajación de los valores sociales ${ }^{4}$. Voces como la de Johnson fueron replicadas a lo largo de los Estados Unidos por moralistas e intelectuales, en ocasiones a través de revistas literarias como American Monthly Magazine.

La literatura del género fantástico no tuvo mejor acogida que la realista. En Inglaterra habian empezado a proliferar novelas baratas de terror que serian conocidas con el nombre de penny dreadfuls y que fueron repudiadas por quienes veían en ellas un mero cúmulo de criminalidad y violencia que "envenenan el fundamento mismo de la vida humana, confundiendo la consciencia, pervirtiendo el sentido de lo correcto e incorrecto, corrompiendo e inflamando esas pasiones cuya regulación y coordinación con el deber constituyen la base de la moral y representan la única garantía para la paz"5. Unos argumentos que hallarian eco en Estados Unidos, a medida que su industria editorial empezó a emular este tipo de publicaciones provenientes de la otra orilla del Atlántico.

\footnotetext{
3 Keymer, Tom / Sabor, Peter: The Pamela Controversy: Criticisms and Adaptations of Samuel Richardson's Pamela, 1740-1750, Pickering \& Chatto, London, 2001, vol. 1, pp. 1320.

4 Johnson, Samuel, en The Rambler, núm. 4, 1750, p. 33.

5 Dixon, Hepworth, Daily News (November 2, 1847), p. 3. El texto puede consultarse en King, Andrew / Plunkett, John: Popular Print Media, 1820-1900, Routledge, London and New York, 2004, vol. 2, pp. 198-200.
} 


\section{LAS DIME NOVELS COMO PARADIGMA DE LITERATURA INMORAL}

Desde la primera mitad del XIX, el problema de la inmoralidad en la literatura pareció materializarse en Estados Unidos a través de unas

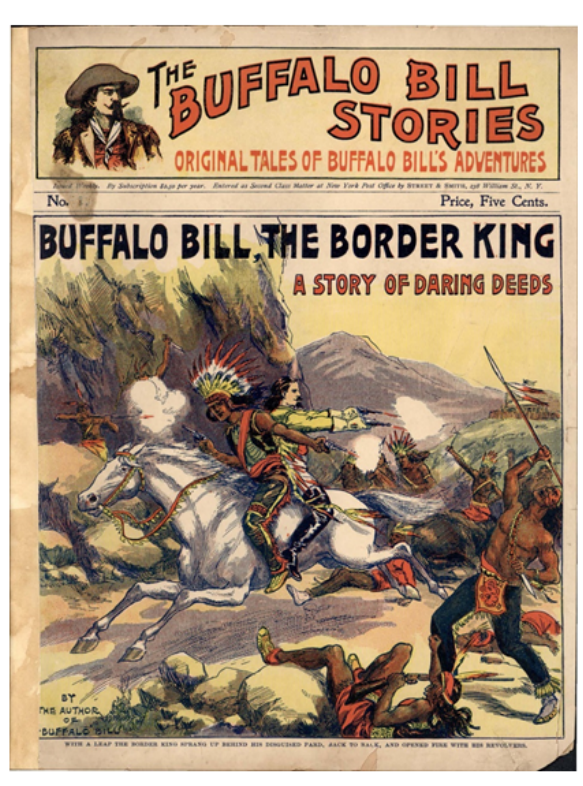

Fig. 1: Ejemplo de "dime novel" obras muy específicas, las dime novels, nombre que procedia del precio de su precio, diez centavos. Nacidas en 1839 con la obra de Ann Sophia Winterbotham Stephens (Malaeska. The Indian Wife of the White Hunter) alcanzarian su esplendor a partir de 1860 con la colección Badles' Dime Novels, dirigida a captar a un público numeroso, como aventuraba su subtítulo ("Books for the Million!")6. A través de las dime novels se popularizó el género del "salvaje Oeste" americano $^{7}$, que tuvo un enorme impacto durante la Guerra de Secesión entre los soldados $^{8}$; incluso Abraham Lincoln era un reconocido consumidor del género literario en cuestión.

Su popularidad no pasó inadvertida a moralistas e intelectuales que despreciaron de inmediato el género por su supuesta deficiencia estética y, sobre todo, por la depravación moral que decian que se desprendia de sus páginas ${ }^{9}$. Es cierto que para atraer a un público más numeroso las dime novels incidieron en temas cada vez más escabrosos, en especial desde 1880, pero no era sólo la crueldad de sus historias lo que preocupaba, sino la presunta desviación de los valores tradicionales. A finales del XIX influyentes educadores acusaban a las dime novels de no proporcionar al lector una clara distinción entre el bien y el mal $^{10}$ y de difundir ideas libidinosas, que incluian descripciones de

${ }^{6}$ Alemán, Jesse / Streeby, Shelley: Empire and the Literature of Sensation. An Anthology of Nineteenth-Century Popular Fiction, Rutgers University Press, New Brunswick, 2007, p. XIX. Esta obra contiene una breve aunque interesante selección de obras pertenecientes a este género literario. En cuanto al bajo coste de las "dime novels", Beadle las publicitaba como "dollar books for a dime". Pearson, Edmund Lester: Dime novels, or Following an old trail in popular culture, Little, Brown and Company, Boston, 1929, Parte I, Capitulo IV. Obviamente no todos pensaban igual. Basta ver el Weekly Times (20-12-1860), p. 5, donde se señalaba que el contenido de las "dime novels" no valía ni un centavo más de lo que se pagaba por ellas.

7 A modo de ejemplo, algunas películas y series del Oeste que han tratado de reflejarlo con mayor realismo han mostrado dime novels. En Sin Perdón (Unforgiven, Clint Eastwood, 1992), uno de los pistoleros, apodado "El Duque" va acompañado precisamente de un escritor de aquel género novelesco, que registra sus andanzas. En la miniserie Hatfields \& McCoys (Kevin Reynolds, 2012) las peleas de las dos familias protagonistas acaban viéndose en el último episodio plasmadas en una dime novel a la venta en el saloon local.

8 Anderson, Vicki: The Dime Novel in Children's Literature, McFarland and Company, Jefferson, 2005, p. 91.

${ }^{9}$ Ibid., p. 82.

10 Jones, Richard: "The Moral and Literary Responsibility of Librarians in Selecting Books for a Public Library (1897)", Schlup, Leonard / Paschen, Stephen H., Librarianship in Gilded Age America. An Anthology of Writings, 1868-1901, McFarland and Company, Jefferson (Noth 
adulterios y raptos de mujeres perpetrados por indios o esclavos negros; un argumento, este último, que en realidad ya habia sido recurrente en Estados Unidos a finales del XVII ${ }^{11}$. Los moralistas más puritanos instaron de inmediato a su prohibición ${ }^{12}$, alegando que promovian "pasiones impuras", y recurrieron incluso a presuntos estudios científicos, como el del médico William Wallace Sanger, quien afirmaba que las dime novels contribuian a la pervivencia de la prostitución ${ }^{13}$.

A comienzos del XX esta idea seguía plenamente vigente, y destacados responsables de la politica cultural, como Arthur Bostwick (presidente de la American Library Association) ejercieron oficiosamente de autoproclamados censores controlando la literatura que debía cubrir los anaqueles de las bibliotecas públicas; literatura de la que, obviamente, quedaban excluidas las dime novels y demás obras consideradas indecentes ${ }^{14}$.

Diluyendo las lindes entre lo moral y lo jurídico, la campaña contra estas obras acabó por imputarles la proliferación de conductas criminales, especialmente entre la juventud. En la prensa de finales del XIX y comienzos del XX aparecieron algunos artículos que relacionaban directamente la lectura de dime novels con la comisión de delitos perpetrados por jóvenes que trataban de imitar lo que en ellas aparecian ${ }^{15}$. De ahí se colegía que las

Carolina), 2009, p. 245. Richard Jones fue profesor de literatura en la Vanderbilt University de Nashville y en el Tufts College de Massachustts.

11 Starker, Steven, Evil Influences. Crusades against the Mass Media, op. cit., pp. 54-55.

12 Ward, H. O.: Sensible etiquette of the best society, customs, manners, morals, and home culture (1878), Porter and Coates, Philadelphia, 1878, p. 405.

13 Sanger, William W.: History of prostitution. Its extent, causes, and effects throughout the World, Harper \& Brothers, New York, 1858, p. 522.

14 Bostwick, Arthur: "The librarian as censor", Libray Journal, vol. 33, núm. 7, 1908, pp. 257-264. Garrison, Dee: Apostles of Culture. The Public Librarian and American Society, 1876-1920, The University of Wisconsin Press, Winsconsin, 2003, p. 100; Preer, Jean: Library Ethics, Greenwood Publishing Group, Westport, 2008, p. 90; Marco, Guy A.: The American Public Library Handbook, ABC-CLIO, Santa Barbara (California), 2012, p. 42. Bostswick, sin embargo, reducía su idea de control a las bibliotecas destinadas al público generalista, no a las bibliotecas de centros de investigación. En 1908, Bostwick organizó una conferencia con el título “¿Qué deben hacer las bibliotecas con los libros malos?” en la que insistió en su rechazo visceral hacia la literatura amoral. Lundin, Anne: Constructing the Canon of Children's Literature. Beyond Library Walls and Ivory Towers, Routledge, New York, 2004, p. 35.

15 A modo de ejemplo un asesinato en Ohio de tres personas a manos del hijo de una de ellas, de dieciocho años de edad, descrito como un lector compulsivo de "dime novels" llenas de crimenes atroces. Williamsport Warren Republican (18-09-1879), p. 1. También el delito de sustracción de caballos por parte de un menor se conectaría con las "dime novels": Eau Claire Daily Free Press (20-01-1880), p. 4. Igualmente, en Stockton, la conducta de tres menores de edad, que pretendian emular a los asaltantes del salvaje oeste, se ligó con la excesiva lectura de aquellas obras. Jeffersonville National Democrat (29-01-1880), p. 3. Un caso de hurto, cometido por un menor de edad que había desaparecido de su hogar, sería narrado en la prensa con el clarificador título "Los efectos leer dime novels". Monticello Express (1-01-1880), p. 4. El mismo artículo aparecería, con idéntico título, en Marion Daily Star (10-01-1880), p. 2. En Nueva York la policía detendría a tres menores en cuyos bolsillos portaban revólveres, junto con diversas "dime novels". Rochester Republican (5-02-1880), p. 4. También en Nueva York se registraría un atentado contra la propiedad privada por dos jóvenes lectores de aquellas obras. New York Times (21-02-1880), p. 1. Otros casos relatados por la prensa, aunque no delictivos, pero también nocivos para la infancia, fueron los de 
denostadas novelas conducian a un embrutecimiento de los menores de edad, actuando como factor condicionante -cuando no causa necesaria- de actividades ilegales ${ }^{16}$. Quizás el caso más llamativo de estos intentos de conexión entre literatura y criminalidad fue el que tuvo a Jesse Harding Pomeroy como protagonista. Autor de uno de los más escabrosos casos de asesinato del último tercio del XIX, el conocido como "niño homicida" perpetró en 1874, cuando apenas contaba catorce años, la mutilación de otros dos niños de su localidad. A Pomeroy, la persona más joven condenada hasta entonces por delito de asesinato, se le relacionó de inmediato con la lectura de dime novels ${ }^{17}$, aun cuando él mismo lo negó ${ }^{18}$.

La banalización de la violencia y el crimen en aquellas lecturas llevó incluso a considerar que interferian en el adecuado desarrollo de la actividad judicial -es decir, en el propio Estado de Derecho- al influir en la psique de los miembros de los jurados populares, inculcándoles prejuicios e ideas preconcebidas ${ }^{19}$. Para paliar tantos males, algunos editores con autoproclamada intención filantrópica promovieron iniciativas destinadas a sustituir las dime novels por lecturas más provechosas para la juventud. Así lo intentó por ejemplo Rowell Smith, fundador de la revista periódica St. Nicholas, que tenía por bandera aportar contenidos edificantes ${ }^{20}$. Otros moralistas, sin embargo, optaron por actitudes más hostiles, como enseguida veremos.

\section{LAS SOCIEDADES DE REPRESIÓN DEL VICIO Y LA CAMPAÑA MORAL CONTRA LA LITERATURA INMORAL}

Las dime novels tuvieron como particular némesis a las denominadas "sociedades antivicio" que empezaron a proliferar en el último tercio del siglo XIX como respuesta a los miedos que la vida urbana había despertado entre la clase media durante los años posteriores a la Guerra Civil21. El más

abandono del hogar para vivir aventuras obtenidas de las "dime novels": Logansport Pharos (12-02-1880), p. 8.

16 Howe, Julia Ward: "The Influence of Literature upon Crime", Papers and Letters Presented at the First Woman's Congress of the Association for the Advancement of Women, New York, 1874, pp. 13-17; Link, Eugene P.: "Abraham and Mary P. Jacobi, "Humanitarianh Physicians"", Journal of the History of Medicine and Allied Sciences, vol. 4, núm. 4, 1949, p. 389.

17 Boston Daily Globe (28-04-1874), p. 1; Daily Nevada State Journal (12-04-1876), p. 2 (el mismo texto en Weekly Nevada State Journal, 15-04-1876, p. 2); Carlisle Democrat (4-041877), p. 1; Greenville Advance Argus (3-04-1879), p. 1.

18 Pearson, Edmund Lester, Dime novels, or Following an old trail in popular culture, op. cit., Parte I, Cap. X.

19 Sullenger, T. Earl: "Popular Attitudes toward the Administration of Criminal Justice", Journal of the American Institute of Criminal Law and Criminology, vol. 20, núm. 4, 1930, p. 517.

20 Eddy, Jacalyn: Bookwomen. Creating an Empire in Children's Book Publilshing. 19191939, The University of Wisconsin Press, Madison, 2006, p. 70.

21 Boyer, Paul S.: Purity in Print. Book Censorship in America from the Gilded Age to the Computer Age, The University of Winsconsin Press, Wisconsin, 2002, p. 33. Este libro, magníficamente documentado, contiene un excepcional análisis de las campañas 
famoso paladín de estas sociedades fue Anthony Comstock ${ }^{22}$, un puritano excombatiente de la Guerra Civil nacido en New Canaan (Connecticut), quien fundaria en 1873 la New York Society for the Suppression of Vice. Ejemplo que poco después sería imitado en Chicago, Louisville, Cincinnati y San Francisco, aunque quizás la más famosa -aparte de la neoyorkina- fue la fundada en Boston: la New England Society for the Suppression of Vice, que en 1891 cambiaria su nombre por el de New England Watch and Ward Society ${ }^{23}$. Una sociedad, esta última, con unas notas particulares, como la mayor presencia del estamento clerical, y el interés por preservar no sólo la moral, sino también la cultura y tradiciones de Boston ${ }^{24}$.

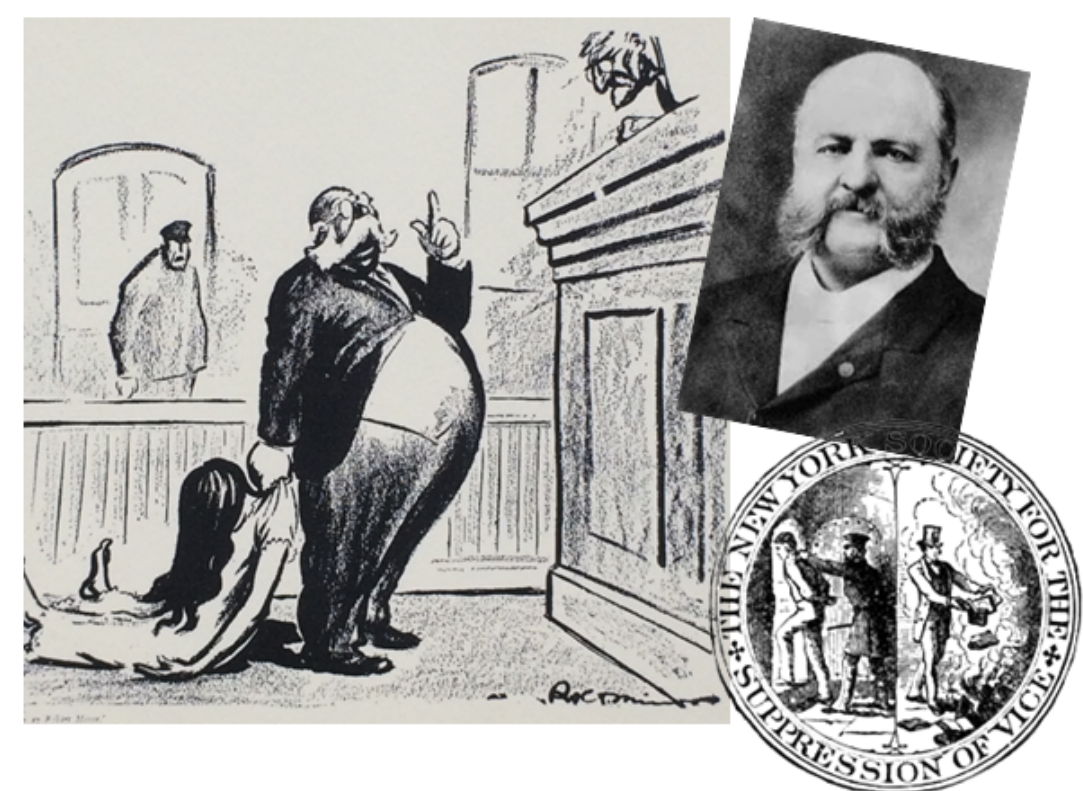

Fig. 2: Retrato de Anthoy Comstock y sello de la Sociedad para la supresión del Vicio de N. Y. En el chiste gráfico Comstock dice al juez "iSeñoría, esta mujer dio a luz a un niño desnudo!"

orquestada contra la literatura obscena en Estados Unidos desde finales del XIX. Sin duda una lectura imprescindible.

22 Sobre Comstock véase: Andrist, Ralph K.: "Paladin of Purity", American Heritage Publishing, vol. 24, núm. 6, 1973. Comstock fue el responsable de la represiva legislación postal estadounidense, que prohibiría la circulación de obras obscenas. Greenberg, Martin Alan: Citizens Defending America. From Colonial Times to the Age of Terrorism, University of Pittsburgh Press, Pittsburgh, 2005, pp. 61-62; Foster, Gaines M.: Moral Reconstruction. Christian Lobbyists and the Federal Legislation of Morality, 1865-1920, The University of North Carolina Press, North Carolina, 2002, pp. 48-54.

23 Fundada en mayo de 1878 en sacristía de la iglesia bostoniana de Park Street, en un acto presidido por Anthony Comstock. Miller, Neil: Banned in Boston. The Watch and Ward Society's Crusade against Books, Burlesque, and the Social Evil, Beacon Press, Boston, 2010, p. 11.

24 Ibid., p. 19. 


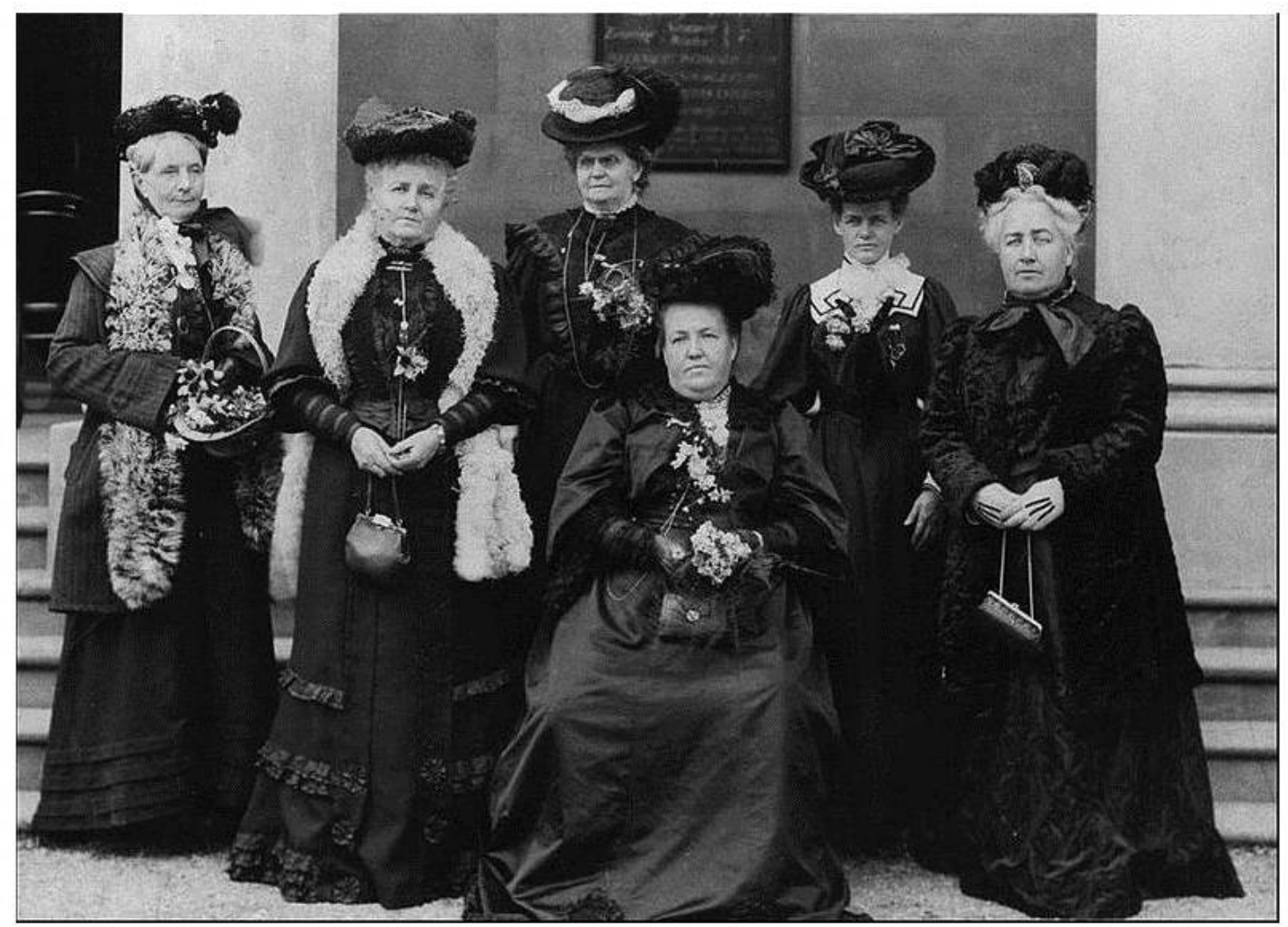

Fig. 3: Miembros de la Woman's Christian Temperance Union, hacia 1900

Las Sociedades para la Supresión del Vicio obtuvieron desde su alumbramiento un sólido respaldo por parte de otras organizaciones cívicas, como la Woman's Christian Temperance Union, que creó un Departamento para la Supresión de Literatura Impura, así como de diarios como el Tribune y el Times de Nueva York, y el Transcript de Boston, que se hicieron eco de sus actividades. Durante algún tiempo, también gozaron de popularidad entre el reformismo progresista, obteniendo el apoyo de las agrupaciones combatientes con la prostitución que acabaron propiciando la Mann Act de 1910, destinada a eliminar el tráfico sexual de mujeres dentro de la Unión. En 1916 la American Social Hygiene Association coincidió con los planteamientos de las Sociedades antivicio al afirmar que una legislación más severa contra las publicaciones obscenas contribuiria notablemente a erradicar el meretricio.

Contando con estos respaldos Comstock y sus imitadores se erigieron en purificadores de los "males morales" que, a su parecer, aquejaban a la sociedad estadounidense. En su intento por eliminar cualquier manifestación de decadencia no dudaron en tratar por igual las estampas "indecentes", las apuestas, la prostitución, las drogas y, cómo no, la literatura. A fin de cuentas, todo ello parecía estar ligado, según sus particulares razonamientos. Las campañas de Comstock y sus acólitos se caracterizaron además por un activismo radical que llevó a sus opositores a acuñar el término "comstockery" como sinónimo de puritarismo y censura 25 .

25 Ibid., p. 12. 
En su cruzada contra la literatura inmoral, Comstock tuvo especial interés en concienciar sobre la incidencia que aquella tenia sobre un grupo particular de ciudadanos, a saber, los menores de edad. Para el fundador de la sociedad antivicio neoyorkina todo material obsceno representaba una "trampa para la juventud", expresión que utilizó para intitular una de sus más conocidas obras: Traps for the Young (1883) ${ }^{26}$. Entre esas trampas, Comstock mencionaba precisamente las dime novels, a las que dedicó todo un capitulo de su libro. Alli las calificaba de material concebido por Satán para tentar a los niños, incapaces de acudir a la iglesia o al colegio sin que sus ojos se topasen por el camino con esas obras expuestas en los comercios aledaños ${ }^{27}$. Como buen puritano, todo se reducía a la simple ecuación de ver al anticristo tras todo cuanto consideraba inadecuado o inmoral. De ahí que, en términos apocalipticos, el oriundo de New Canaan advirtiese a los padres: "vuestro hijo está en peligro de que su mente pura permanezca maldita de por vida" 28 .

Nada edificante podía hallarse en aquellas novelas baratas. Sólo "cuentos tontos e insipidos, historias jergales escritas con el dialecto de las cantinas", romances y detalles exagerados de crimenes, tanto reales como imaginarios. Los lectores sólo obtendrian malas enseñanzas de unos textos que "ensucian la imaginación, destruyen la paz doméstica, destrozan hogares, denigran la virtud femenina, y forjan groseros abusones, vagabundos, ladrones, forajidos y libertinos"29. Esta última percepción ejemplificaba, una vez más, la tendencia a enlazar amoralidad e ilegalidad, y para demostrarlo Comstock describiría en su libro algunos casos verídicos de delitos cometidos por niños, supuestamente a imitación de aquellas execrables lecturas ${ }^{30}$. Eso sí, en ningún momento era capaz de demostrar que existiese una conexión real entre los crímenes perpetrados y la lectura de dime novels.

Estas obritas baratas tuvieron por tanto que someterse a unos nuevos "juicios de Salem", en los que las sociedades antivicio frecuentemente actuaban como acusación particular. Cada vez que detectaban una obra que no encajaba en sus encorsetados estándares morales y estéticos acudian de inmediato a los jueces interponiendo querellas por violación de la normativa antiobscenidad que, heredada del sistema legal británico, se mantenía en la mayoria de los Estados miembros de la Federación estadounidense. De hecho, el control que ejercieron llegó a ser tan estricto que se convirtieron poco menos que en brazos cívicos de la policía ${ }^{31}$.

26 Sobre la autoria de Comstock: Wood, Janice Roth: The Struggle for Free Speech in the United States, 1872-1915. Edward Bliss Foote, Edward Bond Foote, and Anti-Comstock Operations, Routledge, New York, 2008, p. 31.

27 Comstock, Anthony: Traps for the Young, Funk \& Wagnalls Company, New York, 1883 (4 ${ }^{\mathrm{a}}$ ed.), p. 20.

28 Ibid., p. 28.

29 Ibid., p. 25.

30 Ibid., pp. 27-28, 31-36.

31 Ernst, Morris Leopold: The First Freedom, Macmillan, New York, 1946, pp. 17-18. 


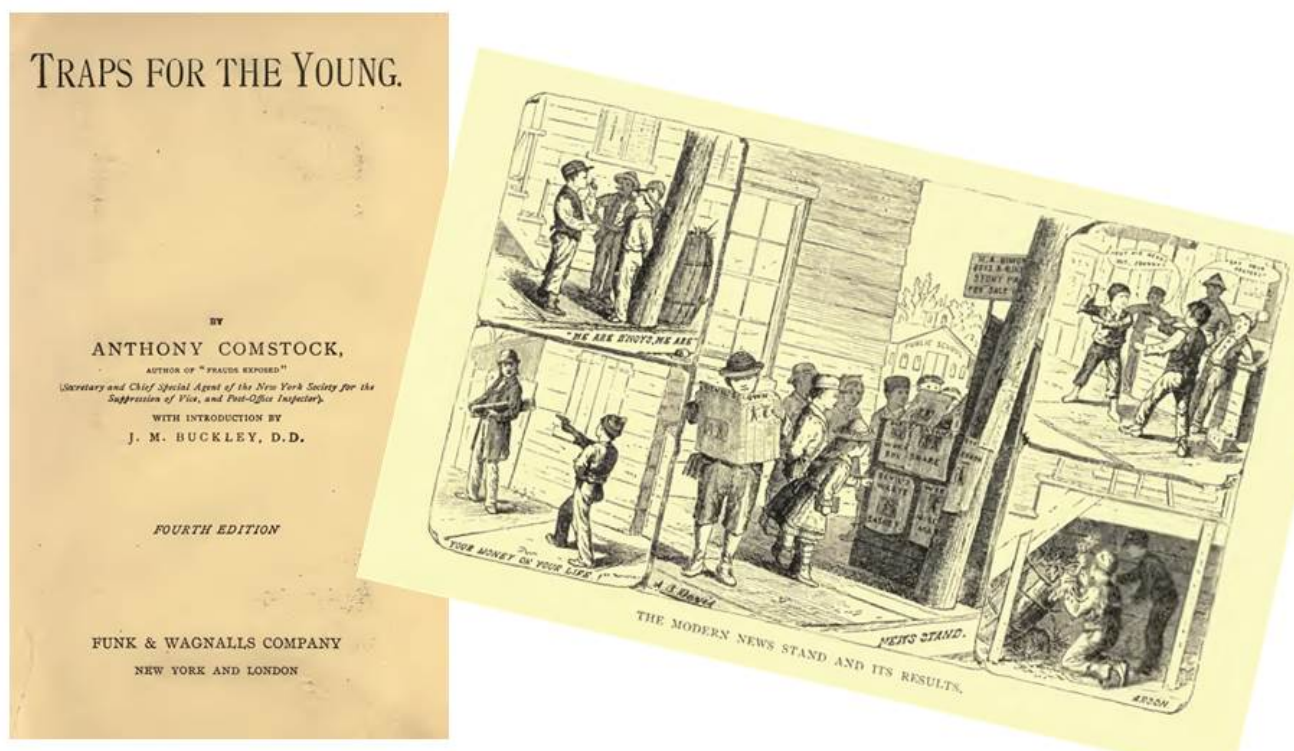

Fig. 4: Portada y primera página de "Traps for the Young", en la que se muestran la presunta corrupción que las lecturas inmorales provocaban en los niños

En el caso de la New England Watch and Ward Society tal circunstancia resultó particularmente evidente desde 1916, momento en el que, bajo el liderazgo de Jason Frank Chase y el apoyo financiero de Martha Hunt, la Sociedad llegó a convertirse prácticamente en una fuerza policial privada: obviamente no podía realizar detenciones, pero persuadia a los jueces para

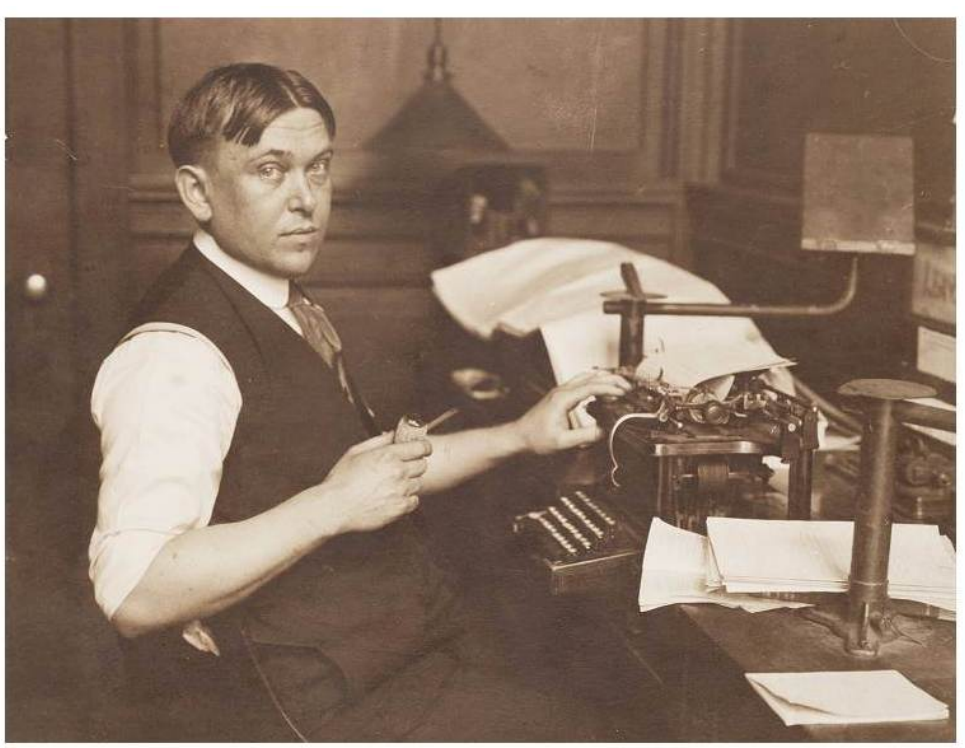

Fig. 5: Henry Louis Mencken que expidiesen órdenes de arresto $^{32}$. A su favor contaba además el apoyo que tenía de algunos miembros de la judicatura, como Charles Benedict, del New York's Southern District Circuit Court, o Samuel Blatchford, elegido como magistrado de la Corte Suprema ${ }^{33}$, quienes siempre parecian presumir la veracidad de la acusaciones vertidas por las Sociedades antivicio.

Ante el riesgo que estas acusaciones de obscenidad suponía para las editoriales, que obtenian pingües beneficios con

32 Miller, Neil, Banned in Boston. The Watch and Ward Society's Crusade against Books, Burlesque, and the Social Evil, op. cit., p. 69.

33 Wood, Janice Roth, The Struggle for Free Speech in the United States, 1872-1915. Edward Bliss Foote, Edward Bond Foote, and Anti-Comstock Operations, op. cit., pp. 43 y 45. 
las dime novels, en Boston el presidente de la Old Corner Bookstore llegó a someterse a la propuesta del Secretario de la New England Watch and Ward Society (el ya mencionado Jason Frank Chase) de crear el Boston Booksellers' Committee ${ }^{34}$. Se trataba de una especie de jurado no oficial, encargado de suministrar a los libreros listados de las obras que, a su entender, podían resultar obscenas. Un sistema, pues, de censura social, no por ello menos severo, puesto que de no atenerse a las "advertencias" del jurado, el vendedor se arriesgaba a una demanda. Este sistema, considerado como un "pacto entre caballeros", funcionó entre 1915 y $1927^{35}$, y aunque el principio pareció satisfacer a ambas partes, no le faltaron críticos, como el escritor e intelectual Henry Louis Mencken, quien consideraba inadmisible que seis personas decidiesen qué podían leer o no los bostonianos, quienes ni tan siquiera llegaban a conocer de qué libros se les estaba privando ${ }^{36}$.

Contrariado con esta censura, Mencken orquestó una activa campaña contra Chase, apoyado en su tarea por A. L. S. Wood, autor de un retrato irónico y corrosivo de Chase para el Mercury. Wood dejaba claro que lo que el Secretario de la sociedad bostoniana habia gestado era una Court of Preventive Criticism o instancia censora: "casi todos los Estados de la Unión tienen una ley tan ofensiva como la de Massachusetts -concluía-. Pero ningún Estado dispone de un sistema perfecto de Crítica Preventiva hasta que no encuentra a su J. Frank Chase"37.

No obstante, los libreros acababan prefiriendo cualquier cosa antes de verse envueltos en una querella, y de hecho, en 1922, la National Association of Book Publishers (formada dos años antes) creó un comité para estudiar las posibilidades de una autocensura a fin de evitar los conflictos con las sociedades antivicio ${ }^{38}$. Ese mismo año, el nuevo presidente de la New York Society for the Suppression of Vice, John Saxton Sumner, propuso a la Authors' League y a veinte editoriales neoyorkinas un plan de censura extralegal, consistente en crear "jurados de libros", integrados por quinientos ciudadanos elegidos por grupos religiosos y civicos, así como por asociaciones profesionales de autores y editores, que se dedicaria a expurgar los libros que le remitieran los editores. En esta ocasión, sin embargo, los editores se negaron a participar en un organismo de censura.

En el caso particular de Boston, el recrudecimiento de la censura que tuvo lugar en los años veinte del pasado siglo -y de los que el Boston Booksellers' Committee no era más que una manifestación- pudo estar influido por las medidas adoptadas en Irlanda, donde en febrero de 1926 el Ministro de Justicia, Kevin O'Higgins, había creado un Committee on Evil

34 Boyer, Paul S., Purity in Print. Book Censorship in America from the Gilded Age to the Computer Age, op. cit., p. 184.

35 Miller, Neil, Banned in Boston. The Watch and Ward Society's Crusade against Books, Burlesque, and the Social Evil, op. cit., pp. 49-50.

36 Ibid., pp. 51 y 103 y ss.

37 Wood, A. L. S.: "Keeping the Puritans Pure", The American Mercury, vol. VI, núm. 21, September 1925, p. 78.

38 Boyer, Paul S., Purity in Print. Book Censorship in America from the Gilded Age to the Computer Age, op. cit., p. 114. 
Literature, y en 1929 se aprobó la Censorship of Publications Act ${ }^{39}$. Sin embargo, no debe obviarse el clima de moralidad que emergió con la primera Guerra Mundial, y que llevó en 1923 a celebrar en la Sociedad de las Naciones una conferencia sobre literatura obscena dando lugar a la International Convention for the Suppression of the Circulation of and Traffic in Obscene Publications (Ginebra, 12 de septiembre de 1923). En todo caso, la presión social acabaría por traer consigo cambios normativos que pondrían las cosas todavía más difícil a la literatura obscena.

\section{LA LEGISLACIÓN ANTIOBSCENIDAD COMO RESPUESTA A LA PRESIÓN SOCIAL}

Las Sociedades Para la Represión del Vicio no se conformaban ni con su presión social ni con acudir al poder judicial. A su entender, había que atajar el mal en su origen, y para ello no quedaba más remedio que

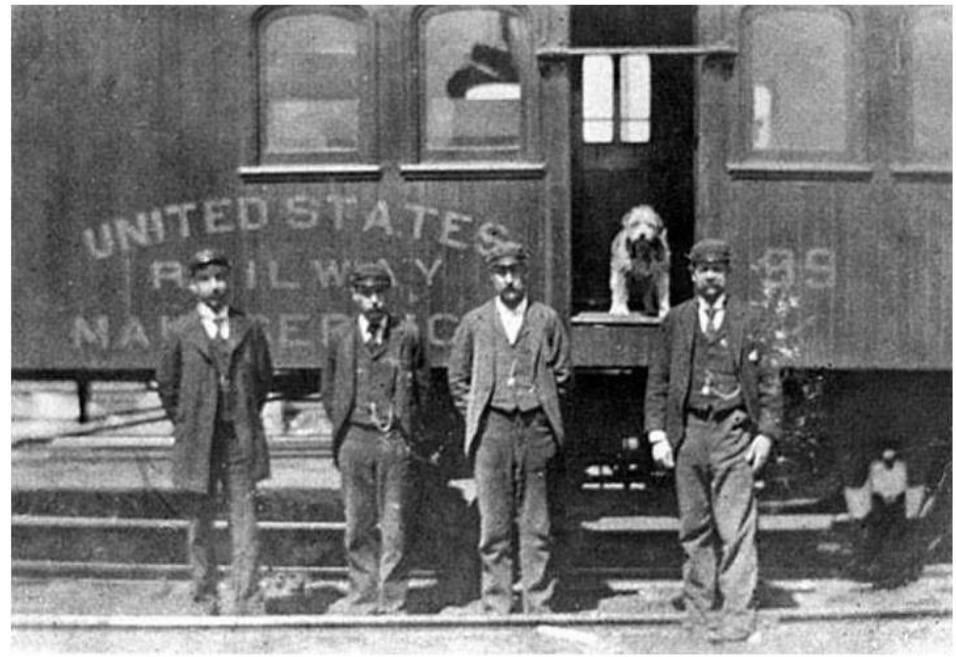

Fig. 6: Empleados del servicio postal de Albany endurecer la legislación para impedir que las publicaciones inmorales pudiesen circular por los Estados Unidos. Para ello, nada mejor que cercenar su principal mecanismo de difusión, la vía postal. Los evangelistas estuvieron entre el grupo que más tempranamente se quejó de que la permisividad de la legislación postal hacía posible la propagación de literatura licenciosa ${ }^{40}$.

Alineándose con esta postura, las sociedades antivicio promovieron reformas legislativas, tanto a nivel federal como estatal, orientadas a restringir el envío de revistas, libros, estampas o cualquier objeto que se considerase obsceno. En realidad, desde mediados del siglo XIX ya existian algunas leyes federales en este sentido, como la Tariff Act (1842), que prohibía la importación de literatura obscena, y la ley postal de 3 de marzo de 1865, que declaraba ilegal enviar por correo objetos "de carácter vulgar o indecente"41. Sin embargo, Anthony Comstock consideraba estas regulaciones insuficientes, y

39 Miller, Neil, Banned in Boston. The Watch and Ward Society's Crusade against Books, Burlesque, and the Social Evil, op. cit., p. 117.

40 Fuller, Wayne E.: Morality and the Mail in Nineteenth-Century America, University of Illinois, Illinois, 2003, pp. 133-134.

41 An Act relating to the postal Laws (March 3, 1865), Section 16. En: Sanger, George P.: The Statutes at Large, Treaties, and Proclamations of the United States of America. From December 1863, to December 1865, Little Brown and Company, Boston, vol. VIIIvol. VIII, p. 507. Wood, Janice Roth, The Struggle for Free Speech in the United States, 1872-1915. Edward Bliss Foote, Edward Bond Foote, and Anti-Comstock Operations, op. cit., p. 46; Foster, Gaines M., Moral Reconstruction. Christian Lobbyists and the Federal Legislation of Morality, 1865-1920, op. cit., p. 48. 
promovió una reforma de la Post Office Act $t^{2}$ que se hizo efectiva el 3 de marzo de 1873, con la aprobación de la que sería conocida como "Comstock Act" 43 . La nueva ley convertía la obscenidad en un asunto federal, sujetando a control cualquier tipo de envío obsceno, en vez de castigar apenas los casos más graves, como se había hecho hasta entonces ${ }^{44}$. Tres dias más tarde, Comstock era nombrado como agente postal especial, erigiéndose de esta forma en curator de su propia obra.

La nueva legislación federal fue imitada por los Estados miembros, que aprobaron sus propias versiones, popularmente conocidas como "Little Comstock Laws", destinadas a evitar que las publicaciones obscenas se distribuyesen a través de transporte intraestatal ${ }^{45}$. Por su parte, la New England Watch and Ward Society promovió la aprobación, en 1880, de una ley en Massachusetts que prohibía la venta de literatura obscena en las estaciones de ferrocarril (su punto habitual de comercialización) incluyendo como tal aquella que "manifiestamente tienda a corromper la moral de la juventud"46. Controlados estos puntos de venta, cinco años más tarde logró que también se vetara en cualquier otro lugar, castigando con hasta dos años de cárcel o multa de entre cien y mil dólares, a quien vendiese, prestase (o tuviese en posesión con ese objetivo) a un menor de edad cualquier libro, panfleto, revista, periódico u otro tipo de impreso corruptor. El mismo castigo se aplicaba cuando se exhibiesen este tipo de publicaciones en algún vía pública, de forma que quedasen a la vista de los niños ${ }^{47}$. En los años veinte, esta estricta legislación sobre obscenidad de Massachusetts trató de suavizarse a través del Massachustts Club Bill, un proyecto de ley que al menos pretendia que para determinar si un libro era obsceno fuese preciso considerarlo en su conjunto ${ }^{48}$. Pero las Sociedades antivicio todavía gozaban de demasiada popularidad; parecian una fuerza imparable en su campaña contra la literatura obscena.

Las dime novels fueron objeto de una persecución uti singulis cuando en 1883 el miembro de la Asamblea del Estado de New York, Able Goddard, presentó una proposición de ley en la que se establecía que

4217 Stat. 283 (June 8, 1872).

43 An Act for the Suppression of Trade in, and Circulation of, obscene Literature and Articles of inmoral Use (March 3, 1873), en Statutes at Large, 42nd Congress, 1st Session, pp. 598600 .

44 Wood, Janice Roth, The Struggle for Free Speech in the United States, 1872-1915. Edward Bliss Foote, Edward Bond Foote, and Anti-Comstock Operations, op. cit., p. 40.

45 Ibid., p. 48.

46 Miller, Neil, Banned in Boston. The Watch and Ward Society's Crusade against Books, Burlesque, and the Social Evil, op. cit., p. 23.

47 An Act Concerning Obscene Publications (Chap. 305, 8 de junio de 1885), en Acts and Resolves passed by the General Court of Massachusetts in the Year 1885, Wright and Potter Printing, Boston, 1885, p. 758.

48 Miller, Neil, Banned in Boston. The Watch and Ward Society's Crusade against Books, Burlesque, and the Social Evil, op. cit., p. 133. 
"cualquier persona que venda, preste, o dé a un menor de dieciséis años cualquier dime novel o libro de ficción sin haber obtenido previamente el consentimiento escrito del padre o tutor del menor, será culpable de delito, castigado con prisión o multa no superior a cincuenta dólares"49.

Una propuesta finalmente rechazada, y que contaba con numerosas indefiniciones, tanto en la calificación del objeto punible (¿qué se consideraba "libro de ficción"?) como en la libertad que confería al juez para determinar la pena privativa de libertad. De ahí que tanto la prensa como diversas revistas literarias y jurídicas acusasen a la propuesta del congresista de constituir un flagrante ejemplo de hipertrofia legislativa ${ }^{50}$ que resultaba "peor que las propias dime novels" 51.

Huelga decir que los defensores de estas últimas no admitieron las acusaciones de inmoralidad e incitación a delinquir de las que aquellas publicaciones eran objeto. Ciertamente podrian carecer de excelencia literaria, pero moralmente resultaban inobjetables ${ }^{52}$ ya que de ninguna manera promovian conductas libidinosas o viciosas ${ }^{53}$ sino que, en realidad, se ajustaban a los estándares morales de la época en que se elaboraban ${ }^{54}$. La imputación de que promovian la criminalidad resultaba todavía más inverosimil, puesto que la mera lectura no resultaba condicionante suficiente para la comisión de delitos ${ }^{55}$. El rechazo de las dime novels, por tanto, era fruto de la ignorancia. Nadie deseaba tenerlas en las bibliotecas y, desde luego, nadie las estudiaba (salvo Pearson, claro está), y era ese desconocimiento el que, a la postre, producía miedos irracionales ${ }^{56}$.

La defensa de las dime novels se hallaba, por supuesto, intimamente ligada al rechazo de la legislación contra publicaciones obscenas y de la actividad desplegada por las Sociedades antivicio. Y en este punto, quizás el

49 "Prohibition of dime literature", The Publishers' Weekly, vol. XXIII, January-June 1883, p. 500. Lo menciona, aunque sin citar el autor de la propuesta, ni el contenido expreso de ésta Starker, Steven, Evil Influences. Crusades against the Mass Media, op. cit., p. 68.

50 Kirby, James: The Legal News, vol. VI, Richard White, 1883, p. 230.

51 Publishers Weekly (28-04-1883), p. 500. En un sentido idéntico: Bismarck Tribune (607-1883), p. 5 y en The Bibliographer. A Journal of Book-Lore, vol. IV (June-November 1883), p. 53. Otros ataques, en tono satírico, en San Antonio Light (21-04-1883), p. 2, donde se pedía que se ampliara el castigo previsto en la ley a los padres que concedieran al menor la autorización para leer las "dime novels".

52 Everett, William: "Beadle's Dime Books", The North American Review, vol. 99, núm. 204, July 1964, p. 308.

53 Pearson, Edmund Lester, Dime novels, or Following an old trail in popular culture, op. cit., Parte I, Cap. X. Shirk, Adam Hull: "The Dime Novel as Literature", The Soil, vol. 1, núm. 1, 1916, p. 40.

54 Pearson, Edmund Lester, Dime novels, or Following an old trail in popular culture, op. cit., Parte I, Cap. I.

55 Esta es la idea que parece subyacer en McKeogh, Arthur / Meloney, William Brown: "It's a Crime!", The English Journal, vol. 18, núm. 8, 1929, p. 634.

56 Pearson, Edmund Lester: "An Amateur's Notions of Boys' Books", Pearson, Edmund Lester, The Library and the Librarian. A selection of Articles from the Boston Evening Transcript and other Sources, The Elm Tree Press, Vermont, 1910, , p. 68. Las mismas palabras en Pearson, Edmund Lester: "Talks about books", Bulletin of the American Library Association, vol. 2, núm. 5, 1908, pp. 159-160. 
paladin más destacado de la postura "anticensura" fue Theodore Schroeder, a quien se puede considerar como el némesis intelectual de Anthony Comstock. Autor de un beligerante periódico antimormón, editado en Salt Lake City y titulado Lucifer's Lantern, Schroeder fundó en 1911 la Free Speech League, orientada a la defensa de la libertad de expresión, como su propio nombre delata. Ese mismo año veía la luz su libro más destacado ${ }^{57}$, un recopilatorio de numerosos estudios previos en el que trataba de mostrar la relevancia constitucional de la legislación antiobscenidad que se estaba alumbrando, tanto a nivel federal como estatal.

La tesis de Schroeder giraba en torno a un postulado que él consideraba indiscutible: las leyes antiobscenidad eran claramente inconstitucionales. En su apoyo, Schroeder alegaba diversas razones de peso. En primer lugar, y centrándose en la legislación federal que restringía las publicaciones obscenas en el ámbito postal (la "Comstock Act"), acudía a una mera cuestión de incompetencia: el Congreso de los Estados Unidos sólo podia fijar las leyes postales "necesarias y propias" (es decir, proporcionadas) para fijar los aspectos materiales, tangibles, fisicos, de las comunicaciones postales. En este sentido, estaba habilitada para determinar las dimensiones de los paquetes, el franqueo preciso, o el tipo de envoltorio admisible, pero no podía legislar sobre el contenido de lo enviado, salvo en el caso de que se remitiese un producto peligroso 58 : el Congreso podía prohibir la circulación de explosivos, pero no de opiniones incendiarias ${ }^{59}$. Si las autoridades entraban a valorar el contenido de los envíos se produciria una discriminación, por cuanto la difusión de una idea se prohibía en atención al medio empleado para difundirla, el postal.

Pero no se trataba sólo de un problema de igualdad -argumento por otra parte no muy convincente, puesto que habia legislación antiobscenidad más allá

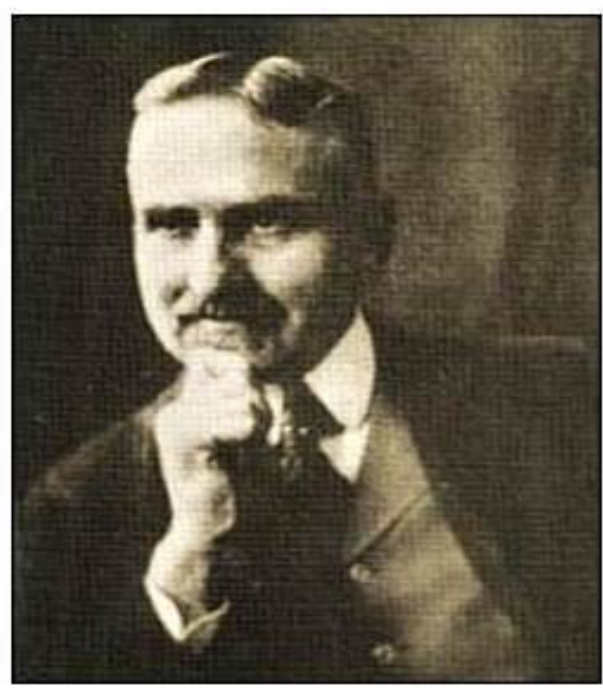

Fig. 7: Theodor Schroeder de la prohibición postal- sino, sobre todo, de las libertades de expresión y prensa. De hecho, el punto fuerte de argumento de Schroeder consistia en considerar que ambas libertades, protegidas por la primera enmienda, no podian ser restringidas por el hecho de considerar que encerraban ideas o conceptos obscenos. Ni la Constitución ni sus "padres fundadores" habian habilitado a limitar aquellas libertades para proteger un presunto valor moral, objetivo que pretendian las leyes antiobscenidad, ni tampoco habían querido circunscribir la libertad de prensa a la ausencia de una previa censura ${ }^{60}$.

57 Schroeder, Theodore: "Obscene" Literature and Constitutional Law, Da Capo Press, New York, 1972 (primera edición de 1911).

58 Ibid., pp. 11-12, 130-141.

59 Ibid., p. 21.

60 Ibid., pp. 12-13, 148-161. 
Tales leyes conculcaban, además, la quinta enmienda, es decir, el "due process of law" o principio de legalidad, aspecto en el Schroeder volcó su mayor caudal argumentativo. A su parecer, ninguna norma había llevado a cabo una definición satisfactoria de qué era "obsceno". Algo que, según él, era de esperar, ya que tal concepto no podia derivar de la naturaleza intrinseca de una lectura, sino que se trataba apenas de una condición o efecto en la mente del lector. Dicho en otros términos: nada podía calificarse, por su propia esencia, de obsceno, por lo que tal caracterización no era más que una apreciación subjetiva, fruto de prejuicios personales e imposible de sujetar a un "test de obscenidad"61. Añadía a este punto argumentos de índole psicológica, al negarse a admitir que la literatura considerada como obscena pudiera resultar en sí misma dañina. Haciendo gala de un notable sentido del humor, afirmaba que nadie en Estados Unidos había visto más literatura obscena que el propio Anthony Comstock, de modo que, siguiendo los argumentos de la campaña antiobscenidad, sólo podía concluirse que éste era un ser sobrenatural, inmune a las tentaciones, o, por el contrario, se había convertido en un pervertido ${ }^{62}$.

Faltando una definición precisa del hecho punible, cualquier intento legal de castigar contradecía dos de las esencias del "due process of law", a saber: la prohibición de sancionar sin una regla de conducta general y cierta, y el rechazo a los denominados "delitos constructivos". En efecto, donde la ley era incierta -como sucedia por la imprecisión de qué era "obsceno"- sólo cabía concluir que tal norma resultaba inválida63 (ubi jus incertum ibi jus nullum). Y la falta de precisión normativa no podia paliarse con un inadmisible activismo judicial que, en ese caso, no estaría interpretando una norma obscura, sino creándola para cada caso ("delitos constructivos") ${ }^{64}$. Al hacerlo, el juez incurriría en otra flagrante infracción muy ligada al "due process of law": la prohibición de legislación sancionadora ex post facto, es decir, la imposibilidad de leyes retroactivas en el ámbito punitivo que castigasen conductas que no estuviesen previamente prefijadas $^{65}$.

Las Comstock Laws fueron igualmente contestadas por un Thaddeus Burr Wakeman en sendos panfletos que circularon tras su aprobación y en los que se cuestionaba su constitucionalidad66. Wakeman (1834-1913) era

61 Ibid., pp. 242, 279-310. Igualmente, pp. 332-341.

62 Ibid., p. 102.

63 Schroeder insistía en que era preciso diferenciar ley "ambigua" de ley "incierta". La primera adolecía de oscuridad, de modo que su enunciado podía albergar diferentes interpretaciones, correspondiéndole a los jueces aclarar su sentido. Pero la ley "incierta" era incompleta, de modo que el juez, al aplicarla, no interpretaba sus términos, sino que los "creaba", incurriendo así en un inadmisible activismo judicial. Este era, precisamente, el caso de la legislación sobre obscenidad. Ibid., pp. 358-359, 403-404.

64 Ibid., pp. 356-415.

65 Ibid., pp. 16, 416-424.

66 Wakeman, Thaddeus Burr: The Comstock Laws Considered As To Their Constitutionality, D. M. Bennett, New York, 1878; Wakeman, Thaddeus Burr: The Unanswered Argument Against the Constitutionality of the So-called Comstock Postal Laws, and for the Inviolability and Free and Equal Use of the United States Mail, National Defense Association, New York, 1880. 
un pensador liberal que había estudiado en Princeton y, tras ejercer como abogado, llegaría a participar en sus últimos años en el Primer Congreso Monista de Hamburgo (1911). En sus panfletos, equiparaba la campaña contra las publicaciones obscenas con el fanatismo de Torquemada y Calvino que contrariaba la libertad de prensa, esencial para evitar un gobierno despótico. Como Schroeder, también Wakeman consideraba que el legislador estaba habilitado constitucionalmente sólo para realizar las regulaciones precisas para mantener materialmente las oficinas y vías postales, pero nunca para interferir en la libre circulación de ideas ${ }^{67}$.

Las dime novels se vieron envueltas en toda esta controversia que les sobrevivió. Antes de que el conflicto sobre la legislación represiva de literatura obscena decayese, las dime novels comenzaron su declive. Así, en el primer tercio del siglo XX aquella literatura que había provocado tanta polémica fue eclipsándose, más por los nuevos gustos de los lectores que por la eficacia de la campaña orquestada contra ella. Sin embargo, la progresiva desaparición de las dime novels vino acompañada del surgimiento de nuevas lecturas que reavivarian las llamas de la contienda. Y las acusaciones de inmoralidad arreciaron.

\section{NUEVAS FORMAS DE LITERATURA Y LA HERENCIA DE LA INMORALIDAD: PULP MAGAZINES Y COMIC BOOKS}

El hueco dejado por las dime novels fue rápidamente cubierto por nuevas fórmulas literarias que seguían su misma intención de llegar a un público amplio. A comienzos del siglo XX las denominadas pulp magazines tomarian el relevo de las dime novels. Se trataba de revistas impresas en un vasto papel de pulpa de madera, de donde derivaba su nombre, y que contenían historias de ficción, salpicadas de ilustraciones. La primera fue Argosy, una publicación de Frank Munsey inicialmente dirigida a niños (con el nombre de The Golden Argosy) que cambió de orientación para enfocarse a un público adulto. El éxito resultó inmediato, y en 1900 alcanzaría una circulación de medio millón de ejemplares mensuales.

La fórmula pronto fue imitada por otras compañias como Street and Smith, Estándar Publications, Dell Publishing y Popular Publications, que inundaron el mercado de pulps. El género alcanzó su mayor expansión durante la Primera Guerra Mundial y sólo decayó a partir de la segunda contienda mundial, cuando fueron reemplazadas por los comic books. Aunque entre los lectores de pulps se contaban personalidades como Theodore Roosevelt, Franklin Delano Roosevelt, Woodrow Wilson y Herbert Hoover68, los consumidores habituales de aquellas revistas eran varones de

67 Wakeman, Thaddeus Burr, The Comstock Laws Considered As To Their Constitutionality, op. cit., pp. 10-18; Wakeman, Thaddeus Burr, The Unanswered Argument Against the Constitutionality of the So-called Comstock Postal Laws, and for the Inviolability and Free and Equal Use of the United States Mail, op. cit., pp. 10-18.

68 Entre los lectores reconocidos también se hallaban personalidades de Hollywood, como la actriz Sylvia Sidney, apasionada de los "pulps" de misterio y detectives. Oakland Tribune (2-04-1933), p. 44. 
clase trabajadora ${ }^{69}$ y con escasa formación académica ${ }^{70}$. Tampoco faltaron los niños y jóvenes entre el público de las pulp magazines ${ }^{71}$. Fácilmente accesibles, se convirtieron en una parte de la cultura de la calle ${ }^{72}$ : "eran intercambiados, celosamente coleccionados y escondidos de los padres vigilantes, que nunca pudieron comprender por qué sus hijos leían aquella basura"73.

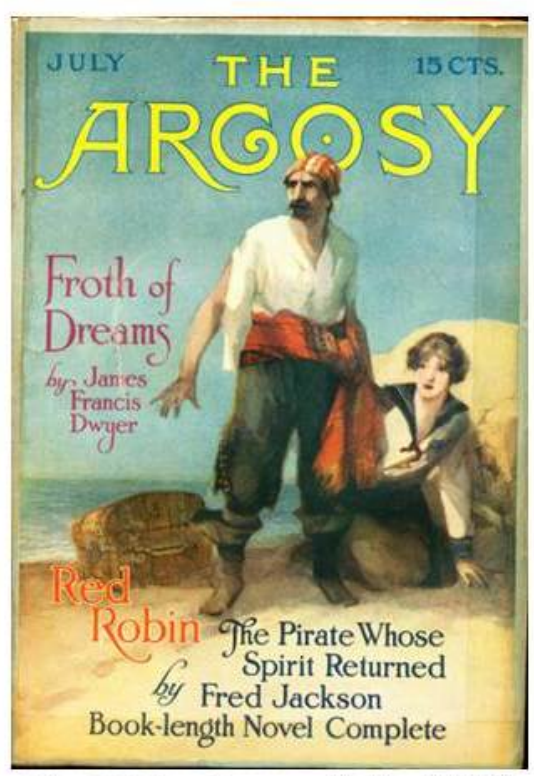

Fig. 7: The Argosy (Julio 1915)

El género de aventuras al que inicialmente se circunscribieron los pulps fue diversificándose a medida que el mercado se ampliaba. Y así, empezaron a ver la luz géneros cada vez más especializados. Tras el éxito de la colección Adventure (Ridgway Company, 1910), en los años veinte aparecerian revistas de aventuras especializadas en el África negra o en Asia, de piratas, de marineros, de boxeadores, ambientadas en la historia, en legión extranjera o referentes a la aviación ${ }^{74}$. Les seguirian pulps sobre el Oeste, la jungla, o la ciencia-ficción que precisamente tuvo en estas revistas su cauce principal de expansión. También allí se difundieron los inmortales personajes e historias de Robert E. Howard (Conan, Elric de Melnibone), Edgar Rice Burroughs (Tarzán) o H. P. Lovecraft (Cthulhu). Pero, como habia sucedido con las dime novels, también las pulp magazines derivaron hacia temas cada vez más escabrosos, acelerando las críticas contra ellos.

El primer aspecto que preocupaba de aquellas revistas era la violencia que irradiaban. Uno de los géneros más inclinados a mostrarla era el detectivesco, temática popularizada a partir de las memorias del conocido detective Alan Pinkerton ${ }^{75}$. Esta linea argumental hizo acto de presencia en

69 Smith, Erin A.: Hard-Boiled. Working-Class Readers and Pulp Magazines, Temple University Press, Philadelphia, 2000, p. 26.

70 Ibid., p. 23. Smith, Erin A.: "Dressed to Kill: Hard-Boiled Detective Fiction, WorkingClass Consumers, and Pulp Magazines", Colby Quarterly, vol. 36, núm. 1, 2000, pp. 11-28; Karetzky, Stephen: Reading Research and Librarianship: A History and Analysis, Greenwood Press, Westport, 1982, pp. 75-95.

71 Forbes, Anita P.: "Combating Cheap Magazines", The English Journal, vol. 26, núm. 6, 1937 , p. 476.

72 Cross, Gary S.: Cute and the Cool : Wondrous Innocence and Modern American Children's Culture, Oxford University Press, Cary, NC, USA, 2004, pp. 131-132.

73 Robinson, Frank M.: The Incredible Pulps. A Gallery of Fiction Magazine Art, Collector Press, Portland, 2006, p. 7.

74 Server, Lee: Danger is my business. Mlustrated History of the Fabulous Pulp Magazines: 1896-1953, Chronicle Books, San Francisco, 1993, p. 56.

75 Goulart, Ron: Cheap Thrills. An Informal History of the Pulp Magazines, Arlington House, New York, 1972, , p. 26. Una interesante selección de estas novelas, dividas en tres bloques temáticos ("Los luchadores contra el crimen", "Los villanos" y "Las damas") puede consultarse en Penzler, Otto: The Black Lizard Big Book of Pulps, Random House, New York, 2007. 
los pulps con la aparición de Black Mask en 1923 (Carroll John Daly y Dashiell Hammett), que populizaría al detective Race Williams, cuya filosofia era la de disparar primero y buscar pistas después ${ }^{76}$. Ávidos de aportar novedades, algunos, como The Phantom empezaron a explotar más las descripciones violentas, al punto de que no tardaron en ser conocidos como "pulps sangrientos"77.

Pero preocupó más, si cabe, la violencia que exudaban las narraciones de terror que proliferaron siguiendo la estela de The Thrill Book (Febrero 1919),
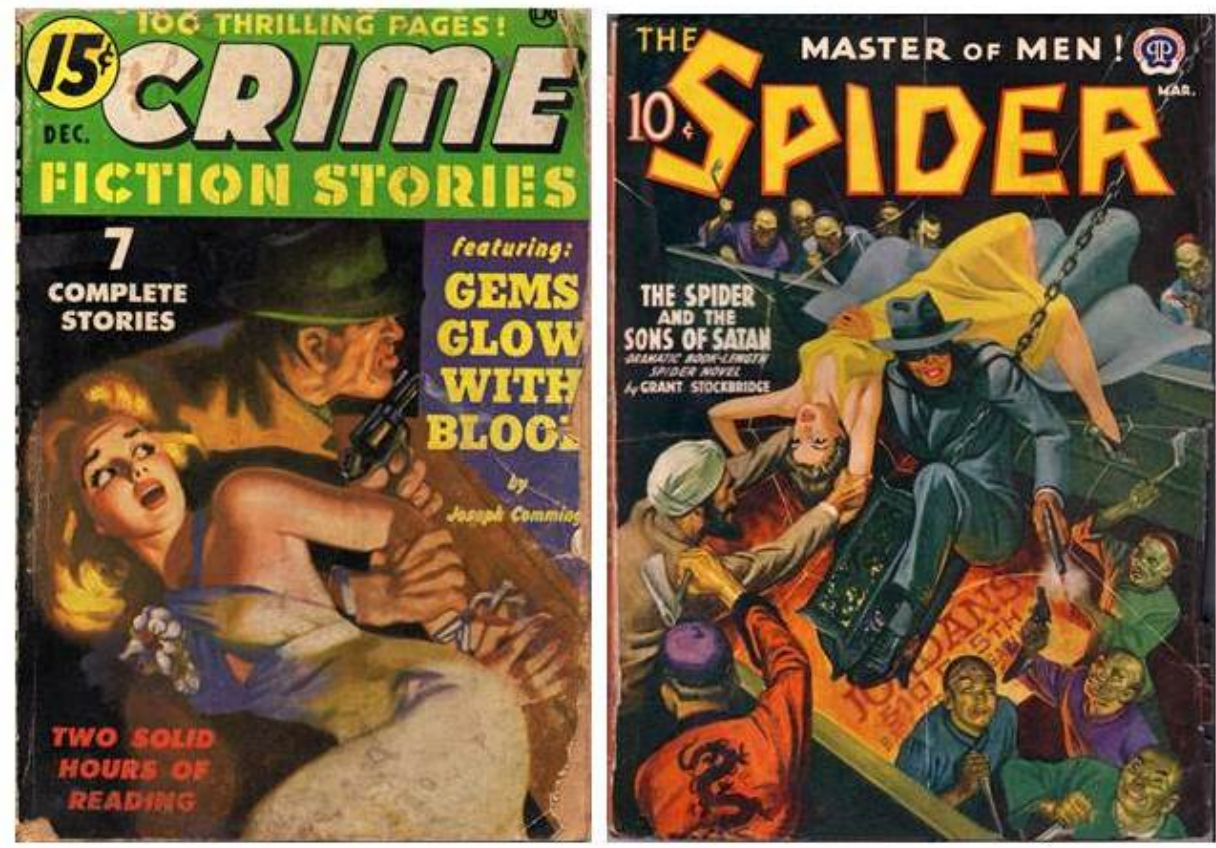

Fig. 8: "Pulps" del género detectivesco

publicado por Street and Smith ${ }^{78}$. El género de terror se especializó, a su vez, en dos líneas, la realista y la sobrenatural, de las cuales la primera fue la que se orientó más hacia los aspectos violentos y sádicos. La precursora de este tipo de terror-realista fue Dime Mystery Magazine (octubre de 1933), de Popular Publications, donde se entremezclaban goticismo, sadismo y amenazas misteriosas, elementos que número tras número se iban agudizando ${ }^{79}$. Siguiendo su truculenta estela aparecieron otras muchas publicaciones del mismo estilo, como Terror Tales (septiembre 1934) y Horror Stories (1935), así como los pulps de la serie "Red Circle" de Martin Goodman (Mystery Tales, Uncanny Tales y Detective Short Stories) ${ }^{80}$, que romperian con todos los tabúes, forjando lo que se conocieron como "pulps escalofriantes"

76 Server, Lee, Danger is my business. Ilustrated History of the Fabulous Pulp Magazines: 1896-1953, op. cit., p. 62 у 65.

77 Hutchison, Don: The Great Pulp Heroes, Book Republic, New York, 2007, p. 94.

78 Server, Lee, Danger is my business. Ilustrated History of the Fabulous Pulp Magazines: 1896-1953, op. cit., p. 33.

79 Jones, Robert Kenneth: The Shudder Pulps: A History of the Weird Menace Magazines of the 1930s, FAX Collector's Editions, Oregon, 1975, pp. 9 y 11.

80 Haining, Peter: The classic era of American pulp magazines, Chicago Review Press, Chicago, 2001, p. 147. 
(shudder pulps). "Sólo en América -diría Bruce Henry- es posible que las masas puedan adentrarse en tareas propias de Torquemada con solo frecuentar el quiosco más cercano"81.
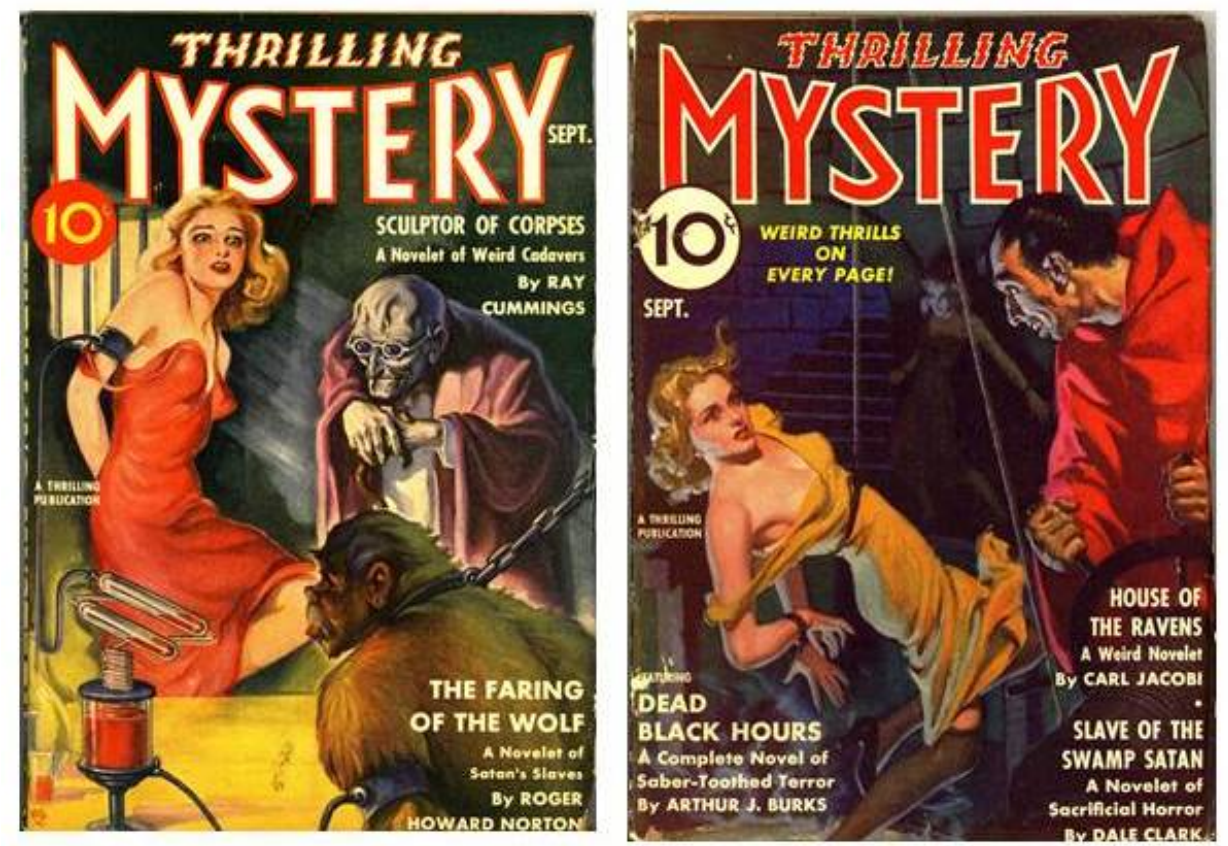

Fig. 9: "Pulps" del género de terror

Obviamente no tardaría en considerarse que tan explicita violencia habría de repercutir en la mente del menor, causándole desórdenes e incentivándole a la comisión de actos criminales ${ }^{82}$. Pero no sólo preocupaba la violencia de los pulps, sino su amoralidad. Se les acusaba de saturar las mentes de los menores y adolescentes ${ }^{83}$, promoviendo entre ellos valores inadecuados y distanciados de los que resultaban tradicionales en Estados Unidos. Muy en particular se les acusaba de despreciar el valor de la familia promoviendo el individualismo y las solitarias andanzas de héroes jóvenes ${ }^{84}$.

Sin embargo, las mayores tachas de inmoralidad atribuidas a los pulps derivaban de las altas dosis de erotismo que desprendian y que supuso que fuesen calificadas por algunos moralistas como lecturas obscenas ${ }^{85} \mathrm{y}$

81 Henry, Bruce: "Horror on the Newsstands", The American Mercury, April 1938, p. 432.

82 Weeks, Arland D.: "The Mind of the Citizen", American Journal of Sociology, vol. 21, núm. 3, 1915, p. 384. En la prensa: Appleton Post Crescent (3-12-1938), p. 9; Sandusky Star Journal (27-07-1937), p. 4. Una curiosa inversión de los argumentos la hallamos en Reno Evening Gazette (19-10-1938), p. 4, donde se afirmaba que cada vez más mujeres se convertian en agentes de autoridad debido a la lectura de "pulps" sobre detectives. Argumento un tanto curioso, ya que en los "pulps" no había demasiadas heroínas, con la excepción de algún caso aislado, como la enmascarada "Domino Lady".

83 Sólo a modo de ejemplo, véase entre la prensa: Appleton Post Crescent (20-04-1938), p. 16; Hammond Times (2-12-1936), p. 22.

84 Cross, Gary: Men to Boys : The Making of Modern Immaturity, Columbia University Press, New York, NY, USA, 2010, p. 100. La acusación de que los "pulps" contribuían a romper familias la expuso, por ejemplo, el Dr. Paul Popenoe, director de "Los Angeles Institute of Family Relations". Valley Star Monitor Herald (12-09-1937), p. 29.

85 Beatrice Daily Sun (12-04-1935), p. 4. 
pornográficas ${ }^{86}$. Más allá del inocuo género romántico, iniciado por Street and Smith con Women's Stories (1921) y Love Story (1929), el auténtico rechazo llegó con el género "picante" (spicy). Éste nació a raíz de Snappy Stories (1912), a la que siguieron Saucy Stories (1915), y Pep Stories y Spicy Stories $^{87}$ (ambas en 1922). Muchas de estas revistas procedian de compañias independientes, por lo que se publicaban de forma irregular 88 y en los puritanos Estados Unidos tenían dificultades para difundirse: más que en kioscos, se distribuían en estancos, donde tenían que ser adquiridas "bajo el mostrador", es decir, previa solicitud del comprador, al no hallarse expuestas ${ }^{89}$.

Las denominados spicy pulps se difundieron a partir de 1934, momento en el que extendieron sus eróticos tentáculos a todos los géneros (western, detective y aventura), confiriéndoles un sentido sexual que incluso habilitaba a un incremento en el precio de venta ${ }^{90}$. Muy en particular afectó al género de terror, sobre todo a las historias de horror "sobrenatural" narradas en publicaciones del tipo de Weird Tales ${ }^{91}$. Las torturas a las protagonistas acababan en ropas desgarradas y en descripciones sádicas de explícito sentido sexual. Yendo incluso más allá, la historia "The Loved Dead", de Clifford Martin Eddy y publicada en Weird Tales en Mayo/Julio 1924, describió actos de necrofilia, lo que suscitó una reacción tal, que el editor se vio obligado a retirar numerosos ejemplares de sus puntos de venta ${ }^{92}$. De hecho, hacia 1937, las historias de terror trocaron lo "esotérico" por lo "erótico", poniendo el acento en aspectos sexuales cada vez más evidentes, siendo "Popular Publications" líder en tales cambios"93.

Sobre todo, el erotismo se materializó en las portadas, con el objetivo de atraer al lector masculino. Salvando la excepción de Thrilling Mystery, que solia retratar en portadas a mujeres modestamente vestidas ${ }^{94}$, la tónica general fue emplear el reclamo erótico en las cubiertas, que combinaban sexo y violencia a partes iguales. Un claro ejemplo fue Mystery Novels and Short Stories (hasta 1939)95 o Mystery Adventures, cuyas portadas, magistralmente elaboradas por Norman Saunders, mostraban de formar

86 Daily Hawk Eye Gazette (26-02-1938), p. 4.

87 Haining, Peter, The classic era of American pulp magazines, op. cit., p. 29.

88 Server, Lee, Danger is my business. Illustrated History of the Fabulous Pulp Magazines: 1896-1953, op. cit., p. 85.

89 Haining, Peter, The classic era of American pulp magazines, op. cit., p. 26.

90 Server, Lee, Danger is my business. Ilustrated History of the Fabulous Pulp Magazines: 1896-1953, op. cit., p. 86.

91 Ibid., p. 36.

92 Haining, Peter, The classic era of American pulp magazines, op. cit., p. 106.

93 Jones, Robert Kenneth, The Shudder Pulps: A History of the Weird Menace Magazines of the 1930s, op. cit., pp. 121-122.

94 Ibid., p. 30.

95 Ibid., p. 145. 
recurrente a mujeres prácticamente desnudas y sometidas a crueles vejaciones $^{96}$.
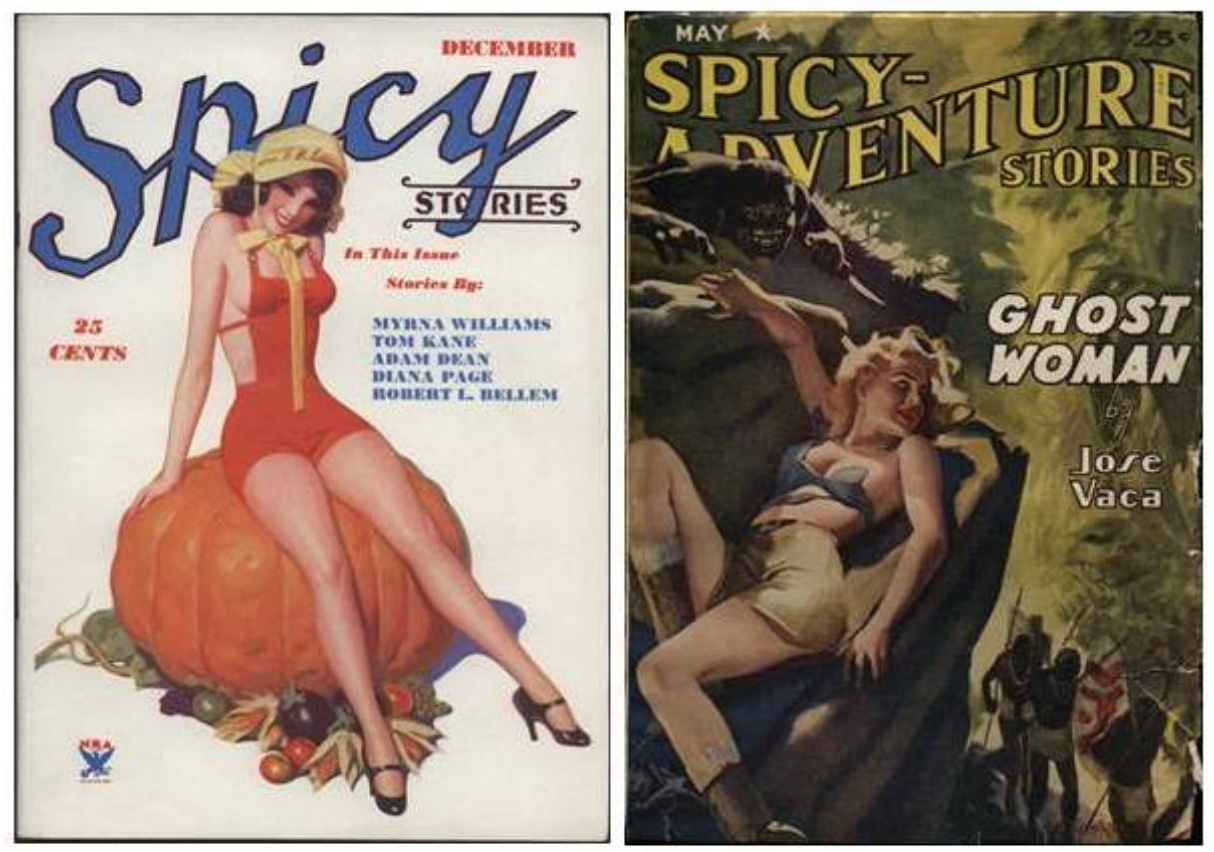

Fig. 10: "Pulps" del género "spicy" o "saucy"

Las criticas a los pulps no tardaron en ser heredadas por otras formas literarias, como los libros de bolsillo y, sobre todo, los comic books. Estos últimos surgieron como una mixtura entre las tiras cómicas que publicaban los periódicos, y las pulp magazines. Inicialmente se centraron en el género de humor (Famous Funnies, Fun Comics, Funny Picture Stories o Animal Comics) de donde derivó el nombre que los popularizaría. Pero no tardaron en absorber los géneros que ya habian explotado previamente las pulp magazines, en especial la ciencia-ficción, temática en la que destacaron Fiction House (Fight Comics, Wings Comics, Planet Comics), Detective Comics (Adventure Comics), Quality Comics (Crack Comics, Blackhawk, Hita Comics), o Fox (Mystery Men Comics, Fantastic Comics, Blue Bettle, Wonder Comics).

El punto de inflexión llegaría en 1938, con la publicación del primer número de Action Comics, en el que vería la luz Superman. Con él nacería el género de los superhéroes, que gozaría de enorme éxito hasta finales de la Segunda Guerra Mundial. Durante la campaña militar, muchos de los soldados se convirtieron en consumidores asiduos de comic books, que incluso mantuvieron un tono patriótico a fin de estimular a las tropas. Tras el fin de la contienda bélica, los editores intentaron mantener fieles a esos lectores adultos que, sin embargo, querian algo distinto a los superhéroes. Y ahí nació una extraordinaria diversidad de géneros, que abarcó desde los crime comics (liderados por la editorial Lev Gleason) a los cómics de terror (en especial Entertainment Comics), jungla (Fiction House), romance (St. John Publications), oeste o bélicos.

Los cómics empezaron entonces a someterse a las mismas críticas que habían padecido las pulp magazines. Se los acusaba de violentos, y de

96 Ibid., p. 71. 
promover la delincuencia juvenil, muy en especial el género policíaco conocido como Crime Does Not Pay, es decir, "el crimen no compensa" 97 . Las historias de estos cómics en realidad daban una imagen justo contraria: el gánster era ajusticiado al final, ciertamente, pero en una sola viñeta; el resto de la historia glorificaba al delincuente mostrando una vida llena de riesgo, pasión y lujos. Otra de las críticas habituales en las pulp magazines también alcanzó a los cómics, a saber, su exacerbado erotismo. Y es que algunas de las editoriales, como Fox y Fiction House, tenian una marcada tendencia a mostrar personajes femeninos hipersexualizados, en un intento evidente por atraer al público masculino.
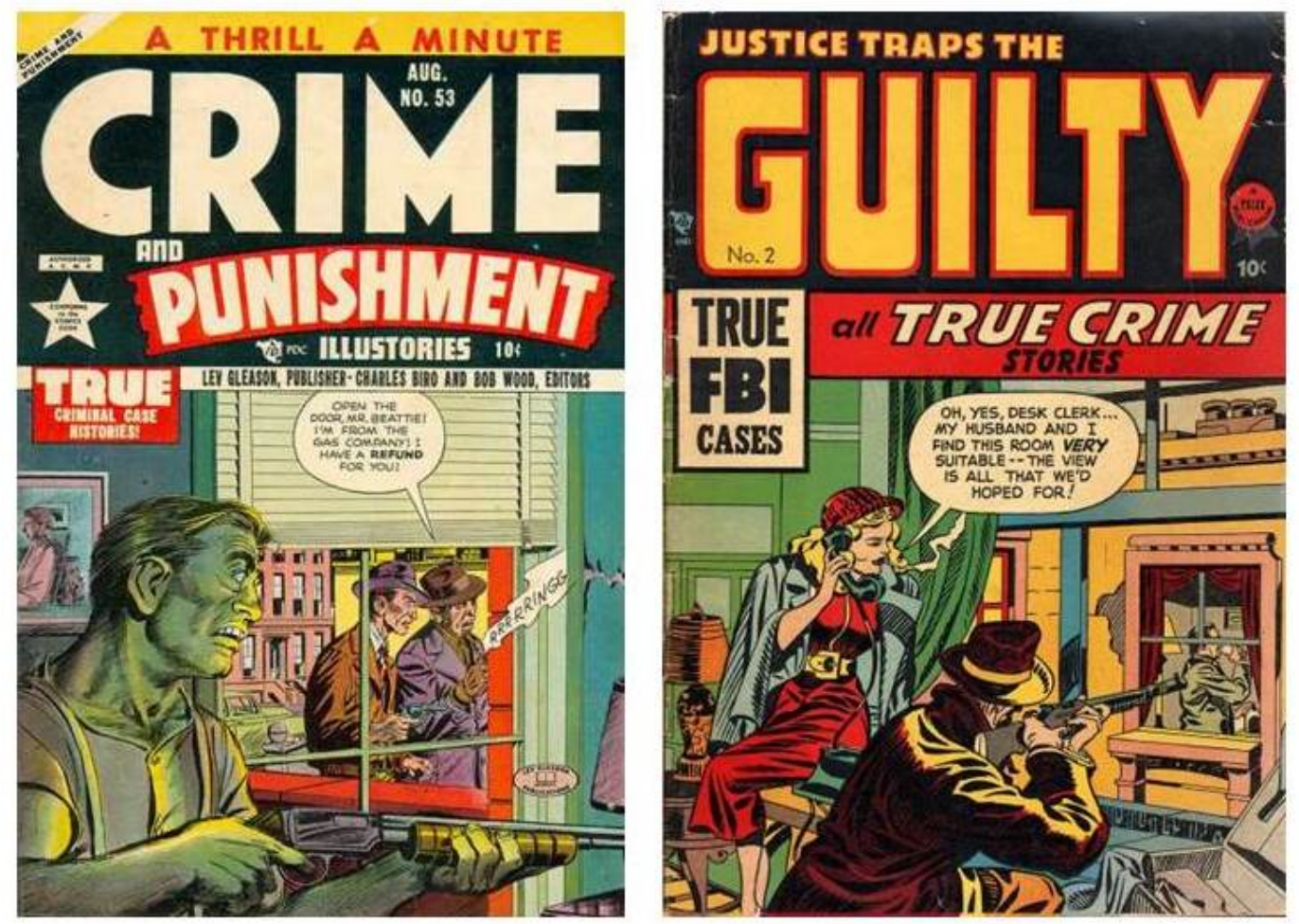

Fig. 11: Cómics del género criminal

\section{CAMPAÑA SOCIAL Y MEDIDAS LEGISLATIVAS CONTRA LAS PULP MAGAZINES}

Tal y como había sucedido con las dime novels, las pulp magazines y los comic books sufrieron el acoso de una activa campaña social en su contra. Particularmente cruento para los pulps fue el periodo 1923-1925, momento en el que se desarrolló la denominada "Cruzada de libros limpios" (Clean Books), considerada por algunos como el mayor desafio para la libertad de prensa estadounidense en el siglo $\mathrm{XX}^{98}$. Buena parte de la campaña estuvo

97 Véase al respecto Fernández Sarasola, Ignacio: "Cómics y delincuencia juvenil en Estados Unidos durante la Golden Age", Tebeosfera, núm. 12, 2014, pp. 1-65.

98 Boyer, Paul S., Purity in Print. Book Censorship in America from the Gilded Age to the Computer Age, op. cit., p. 122. 
dirigida en Nueva York por el ya citado John Saxton Sumner, a la sazón apoyado por John Ford, juez de la New York State Supreme Court.

El objetivo compartido era, una vez más, ahondar en la legislación antiobscenidad, a cuyo fin se redactó un proyecto de ley, presentado en ambas cámaras del Parlamento de Albany el 23 de marzo de 1923, respectivamente por el diputado George N. Jesse y por el senador Salvatore A. Cotillo. El conocido como proyecto Jesse-Cotillo pretendia reformar la Sección 1141 del Código Penal del Estado de Nueva York en varias líneas claramente regresivas: por una parte, permitiendo que la formulación de cargos pudiera realizarse sobre la base de una parte de un libro o revista, de modo que sólo ese fragmento (y no su totalidad) se utilizase como evidencia en el proceso judicial; por otra, ampliando el significado de los términos "indecente" (filthy) y "repugnante" (disgusting) ya previstos en el Código Penal, de modo que pudiesen aplicarse también a contenidos no estrictamente sexuales; finalmente, imponiendo el juicio por jurados y la intervención de expertos en todos los procesos por obscenidad.

Sin embargo, el apoyo al proyecto de ley empezó a decaer en el transcurso de su tramitación legislativa en el Senado, en parte por el miedo a que las medidas que pretendian adoptase hicieran que Nueva York dejase de ser el epicentro editorial de Estados Unidos. En la votación final (3 de mayo de 1923) el Senado rechazó el texto por treinta y un votos frente a apenas quince ${ }^{99}$.

Este revés no desanimó a los partidarios de la "Campaña de Libros Limpios", y en 1924 se presentó un nuevo proyecto en el Parlamento del Estado neoyorkino ${ }^{100}$, aunque algo más flexible que el anterior ya que, por ejemplo, permitía que la defensa de un libro acusado de obscenidad pudiese emplear en su apoyo pasajes distintos a aquellos que habian ocasionado la orden judicial, si bien nunca el libro en su conjunto ${ }^{101}$. El juez John Ford, que apadrinaba el texto, lo justificó una vez más, alegando que Estados Unidos se había convertido "en el vertedero literario del mundo"102.

A pesar de ello, el proyecto obtuvo un clamoroso rechazo cuando en el Senado apenas fue apoyado por cuatro parlamentarios, frente a cuarenta y siete que se pronunciaron en su contra ${ }^{103}$. Haciendo gala de un ánimo irreductible, los partidarios de la campaña "libros limpios" volvieron a intentar en diversas ocasiones revitalizar el texto. Así sucedió en 1925, a

99 "Book censorship bill beaten 31 to 15 by vote in Senate", Daily Sentinel (3-05-1923), p. 5; "Clean Book Bill Dies in Senate", The New York Times (3-05-1923), p. 1.

100 "An Act to amend the Penal Law, in relation to prosecutions for the sale and circulation of obscene or disgusting literature", Journal of the Assembly of the State of New York, New York State, New York, 1924, , vol. I, p. 536; Journal of the Senate of the State of New York, New York State Senate, 1924, vol. 2, vol. I, p. 281. El proyecto puede consultarse también en: "Another Dangerous Bill", Olean Evening Herald (22-03-1924), p. 8 y en Greater New York (1925), p. 31.

101 "Book Censorship Again", Frederick News Post (10-01-1924), p. 5.

102 "Clean Books", Galveston Daily News (22-06-1924), p. 4.

103 Journal of the Senate of the State of New York, op. cit., vol. 2, vol. II, p. 951. En la prensa: "Defeated again", Titusville Herald (16-04-1924), p. 4; Mexia Daily News (5-05-1924), p. 2 . 
través del Senador William Love ${ }^{104}$, con una iniciativa que moriria en comité, y luego, de forma sucesiva, hasta 1929, momento en que la nueva propuesta fue rechazada por ambas cámaras del Parlamento neoyorkino.

Estos continuos reveses minaron la imagen de la campaña "procensura", a pesar de que John Ford trató de exponer sus argumentos en su libro Criminal Obscenity. A Plea for Its Suppresion (1926) ${ }^{105}$. Congratulándose de la pérdida de popularidad de los autoproclamados censores, Mencken y Nathan escribian:

\begin{abstract}
"Están empezando a tener dificultad en convencer a los demás de su dignidad e importancia. Han pedido aplausos y han obtenido chasquidos de disgusto. Para ser censor, hoy en día, un hombre no sólo debe ser un idiota, sino también un hombre lo suficientemente valiente en su estupidez como para aguantar las disimuladas mofas de sus vecinos de puerta"106.
\end{abstract}

Poco después, Mencken llegaría a ligar la campaña procensura con la Ley Volstead, la conocida ley antialcohol: ni la primera serviría para forjar una nación casta, ni la segunda para formar una nación abstemia ${ }^{107}$.

Pero, aunque la campaña "Libros Limpios" hubiese fracasado en otros Estados importantes, como Nueva York, sus instigadores intentaron un nuevo asalto, esta vez en el ámbito federal. Una campaña que tuvo como objetivo más claro a las revistas consideradas inapropiadas para la infancia -como los propios pulp magazines- a las que algunos consideraban como más dignas de censura por representar la más degradada variedad de literatura ${ }^{108}$. Para detener su difusión, en 1927 Thomas W. Wilson, de Coldwater (Mississippi) introdujo en el Congreso un proyecto de ley proponiendo el establecimiento de un National Board of Magazine Censorship ${ }^{109}$.

Bajo la apariencia de arte, decía, estas "revistas baratas" mostraban constantemente imágenes indecentes, señalando los ejemplos de Film Fun ${ }^{110}$,

104 Journal of the Senate of New York, New York State Legislature. Senate, New York, 1925, vol. 2, vol. I, p. 10; ibid., vol. II, p. 728. New York. Legislative Documents, J. B. Lyon Company, New York, 1925, vol. 18, vol. XVIII, p. 161.

105 Ford, John: Criminal Obscenity: A Plea for Its Suppression, F. H. Revell Company, New York, 1926.

106 Mencken, Henry Louis / Nathan, George Jean: "Clinical Notes", The American Mercury, vol. III, núm. 11, November 1924, p. 312.

107 Mencken, Henry Louis: "Comstockery", Mencken, Henry Louis, Prejudices: fifth series, Alfred A. Knopf, New York, 1926, p. 21.

108 Van Loon, Hendrik Willem: "Uplift Journals Please Copy!", Commonwealth, vol. 1, núm. 8, 31-12-1924, pp. 202-203.

109 Journal of the House of Representatives of the United States, U.S. Government Printing Office, 1927, p. 172; "Government Censorship of All Magazines Is Proposed by Congressman Wilson", The Evening News (10-02-1927), p. 32; Dutcher, Rodney: "At the Capital", Miami Daily News (9-02-1927), p. 6; "Mississippian Ask Magazine Gag Board", Biloxi Daily Herald (17-12-1927), p. 1.

110 Sesión de 8-02-1927, Congressional Record. Proceedings and Debates, The Congress of the United States of America, Washington, 1927, vol. 68 (Cong. 69, Sess. 2 - Parts 1-3), vol. 68 (Cong. 69, Sess. 2 - Parts 1-3), p. 3264. 
Saucy Stories y Snappy Stories ${ }^{111}$. Su propuesta consistía en introducir una "sana y vigorosa censura"112, intención en la que obtuvo el respaldo del congresista Albert Johnson, quien añadió la guinda nacionalista al debate: esas perniciosas revistas eran producidas en muchas ocasiones por editores con apellidos extranjeros que estaban contaminando la identidad nacional, a la par de difundir ideario comunista ${ }^{113}$.

Aunque el proyecto de Wilson fracasó, un año más tarde el congresista de Arkansas John N. Tillman introdujo un proyecto similar ${ }^{114}$. Su objetivo era, según sus palabras "separar a la gente joven de ciertas influencias contaminantes"115, entre las que también incluia al cine y al jazz. Tillman mostró a sus compatriotas ejemplares de Telling Tales ${ }^{116}$, a fin de que pudieran ver, con sus propios ojos, aquel "reprobable material" que era leído mensualmente por un millón y medio de personas ${ }^{117}$.

A igual que en el caso del proyecto de Wilson, también el de Tillman fue rechazado en Comisión y, por tanto, no llegaría a ser debatido en el pleno. Sin embargo, las pulp magazines quedaban marcadas de forma singular. En algunas ciudades, las autoridades locales se mostraron extremadamente activas a la hora de controlar la difusión de este tipo de publicaciones. Tal fue el caso de Nueva York, cuyo alcalde, Fiorello La Guardia, intentó suprimir las spicy pulps, a no ser que se cambiasen sus portadas y se vendieran "bajo el mostrador"118. La presión surtió el efecto requerido, y en los años treinta la línea de publicaciones spicy se sustituyó por la línea speed; un cambio nominal que pretendia evidenciar el abandono del erotismo más acendrado ${ }^{119}$.

Por su parte, en el ámbito federal el debate sobre la censura se apartó más de las pulp magazines, por cuanto se centró en los intentos de evitar la importación de obras obscenas (legislación aduanera), más que su circulación por territorio nacional (legislación postal). La competencia federal para prohibir literatura obscena se remontaba a la legislación sobre tarifas proteccionistas (Tariff of 1842, también denominada Black Tariff), y se habia ido renovando en la legislación sobre tarifas sucesivamente aprobada. La

111 Ibid., p. 3266.

112 Ibid., p. 3267.

113 Ibid., p. 3276.

114 A Bill establishing a national board of magazine and book censorship and designating the duties and powers thereof, Sesion de 20-01-1928, Congressional Record. Proceedings and Debates, The Congress of the United States of America, Washington, 1928, vol. 69 (Cong. 70, Sess. 1, Part 1), vol. 69 (Cong. 70, Sess. 1, Part 1), p. 1833. El debate en la session de 26-01-1928, en ibid., pp. 2077-2078.

115 Ibid., p. 2078.

116 Sesión de 26-01-1928, en ibid., p. 2077-2078. El volumen que exhibió fue: Telling Tales [v34 \#2.

117 Ibid., p. 2078.

118 Jones, Robert Kenneth, The Shudder Pulps: A History of the Weird Menace Magazines of the 1930s, op. cit., , p. 211 . Hutchison, Don, The Great Pulp Heroes, op. cit., p. 166.

119 Server, Lee, Danger is my business. Ilustrated History of the Fabulous Pulp Magazines: 1896-1953, op. cit., p. 89. 
decisión de vetar una importación correspondía al inspector local del puerto, si bien, a fin de unificar decisiones, a mediados de los años 20 el Customs Court empezó a promulgar algunas reglas que fijaban la prohibición general de determinados títulos que sin embargo quedaban sujetas a revisión por el Departamneto del Tesoro ${ }^{120}$. Debido a la arbitrariedad con la que podían operar los agentes aduaneros, en 1928 las autoridades federales encargaron a los abogados del Customs Bureau y del Post Office Department que elaborasen una lista negra de setecientos libros que no podian ser importados ni tampoco transmitidos por vía postal ${ }^{121}$.

Sin embargo, no satisfechos con tamaña restricción, en 1929 el Congreso debatió extender la sección 305 de la Tariff Act (sección dedicada a la obscenidad) con el fin de prohibir la importación de cualquier obra impresa que contuviese imágenes obscenas o de naturaleza inmoral ${ }^{122}$. Los partidarios de la reforma consideraban que introducía coherencia en el sistema jurídico estadounidense: no tenía sentido que las leyes postales impidiesen la circulación de obras obscenas y, sin embargo, estas pudiesen entrar libremente en territorio estadounidense a través de su frontera ${ }^{123}$. Aun asi, la enmienda fue rechazada por un margen muy estrecho (38 frente a 36).

\section{LAS MEDIDAS LEGISLATIVAS CONTRA LOS CÓMICS}

Los cómics se encontraron con escollos normativos acordados por municipios y Estados que dificultaron su difusión a partir de los años cuarenta y cincuenta. Algunas de estas medidas fueron precedidas por la constitución de comités de estudio, como en el Senado de Arizona ${ }^{124}$ y Connecticut ${ }^{125}$, en 1955, y los más tardíos de la Asamblea General de Colorado $^{126}$, del Illinois Legislative Council ${ }^{127}$ y de Rhode Island, todos ellos realizados en 1956. Aunque el más importante, sin duda, fue el organizado en Nueva York, operativo desde 1949 hasta 1955.

120 Paul, James C. N. / Schwartz, Murray L.: Federal censorship. Obscenity in the mail, Free Press of Glencoe, New York, 1961, pp. 40-41.

121 Boyer, Paul S., Purity in Print. Book Censorship in America from the Gilded Age to the Computer Age, op. cit., p. 219.

122 Congressional Record. Proceedings and Debates, The Congress of the United States of America, Washington, 1929, vol. 71 (Cong. 71, Sess. 5, Part 4), p. 4447.

123 Reed Smoot, en ibid., p. 4458.

124 "Legislators Study Juvenile Delinquency Problem", Casa Grande Dispatch (September 30, 1954), p. 4, p. 30.

125 "Assembly Votes Comic Book Probe", Bridgeport Post (January 27, 1955), p. 50; "Whelan To Serve With Probe Group", Bridgeport Post (January 29, 1955), p. 22; "Hearing Shifted To Night Here By Comics Probers", Bridgeport Telegram (March 3, 1955), p. 18.

126 Legislative Council. Report to the Colorado General Assembly. Comic Books: Related Matters and Problems. Research Publication n. 19, Colorado Legislative Council, Denver, November 1956.

127 Restrictions Upon Comics. Report Pursuant to Proposal 437 Sponsored by Representative Ralph T. Smith. Bulletin 2-585, Illinois Legislative Council, Chicago, April 1956. 


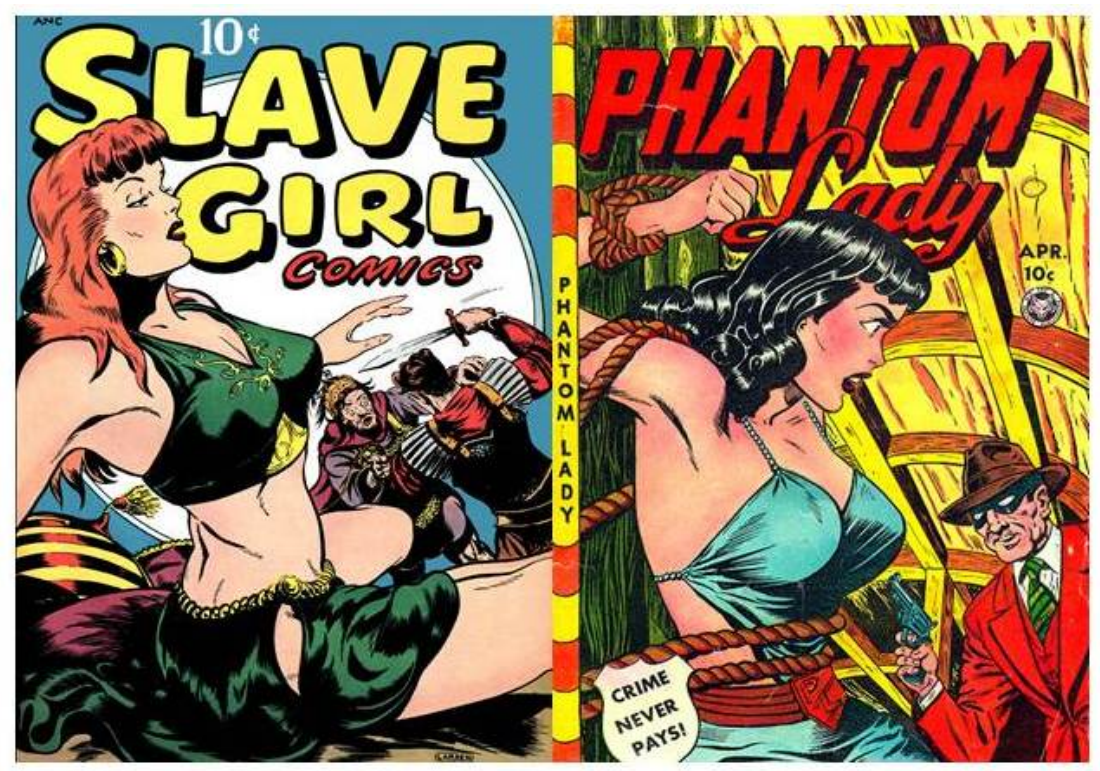

Fig. 12: Muestras de erotismo en el cómic
Dicho Estado contaba con una previsión en su Código Penal que podia extenderse a los crime comics, y que había sido introducida en 1884 a raíz de la campaña promovida por Anthony Comstock y la New York Society for the Supression of Vice junto con la New York Society for the Prevention of Cruelty to Children. Dentro del apartado de "publicaciones y artículos obscenos" del artículo 106 (titulado "Indecencia") se incluía la prohibición de publicar, vender, mostrar o transmitir por cualquier medio publicaciones o material impreso referente "a noticias criminales, informes policiales o actividades delictivas, o imágenes, o historias de actos sangrientos, lujuria o crimen" (Art. 106, Section 1141.2). La previsión normativa no se dirigía inicialmente contra los cómics, inexistentes a finales del XIX cuando se creó la ley, sino contra publicaciones que relataban casos criminales con extrema sordidez, como la Police Gazette fundada en 1845. Sin embargo, tal normativa resultaba también perfecta para atajar los cómics del género de gánsteres.

En otras ciudades y Estados la presencia de cómics sirvió como acicate para promover normas semejantes a la neoyorquina. De hecho, a finales de 1948 la American Municipal Association estimaba que unas cincuenta ciudades estadounidenses habían aprobado ya restricciones a la venta y circulación de cómics ${ }^{128}$, de modo que las medidas destinadas a atajarlos

128 "Unfunny Comic Book Featuring Lust And Mayhem Being Banned", Hutchinson News Herald (October 5, 1948), p. 6; "Progress Being Made in Banning Lurid Comics", Salamanca Republican Press (October 6, 1948), p. 2. Un resumen de estas prohibiciones en: "50 Cities Ban Undesirable Comic Books", European Stars And Stripes (October 10, 1948), p. 9; "Increase Shown On Comic Book Ban In Cities", Altoona Mirror (19 November , 1948), p. 28; "About 50 Cities Prohibit Selling Of Comic Books", Monessen Daily Independent $(22$ November , 1948), p. 8; "Comic Book Bank", Cumberland Evening Times (23 November , 1948), p. 20; "Many Comic Books Held Objectionable", Miami Daily News Record (24 November , 1948), p. 2; "Ban Increases on Comic Books", Mason City Globe Gazette (24 November , 1948), p. 2; "50 Cities Ban Comic Beoks", Indiana Evening Gazette (24 November , 1948), p. 6; "Cities Join Ban Against Comic Books", Mansfield News Journal (25 November , 1948), p. 53; "Comic Book Ban Imposed", Walla Walla Union Bulletin (25 November , 1948), p. 17; "50 Cities Planning Ban on Comic Books", Amarillo Daily News (25 November , 1948), p. 9; "Comics Banned in 50 Cities", Oakland Tribune (25 November , 1948), p. 29; "50 Cities Act to Ban Comic Books", Council Bluffs Iowa Nonpareil (25 November , 1948), p. 20; "50 Cities Take Steps to Ban Comic Books", Statesville Landmark (25 November , 1948), p. 5; "Ban on Comic Books Spreads As Cities Set Up Censorship", Chariton Herald Patriot (25 November , 1948), p. 6. 
habian adquirido ya claramente dimensiones nacionales ${ }^{129}$. Frente a aquellos municipios que habían optado por abstenerse, al considerar que la restricción de las ventas de cómics excedía de su ámbito de competencias, otros Ayuntamientos esgrimieron su capacidad para adoptar esas medidas ${ }^{130}$, fundándose en sus facultades para tutelar la salud pública, la moral y la seguridad avaladas por el Tribunal Supremo (Sullivan $v$. City of Los Angeles, 116 Cal. App. 2d 807, 1953).

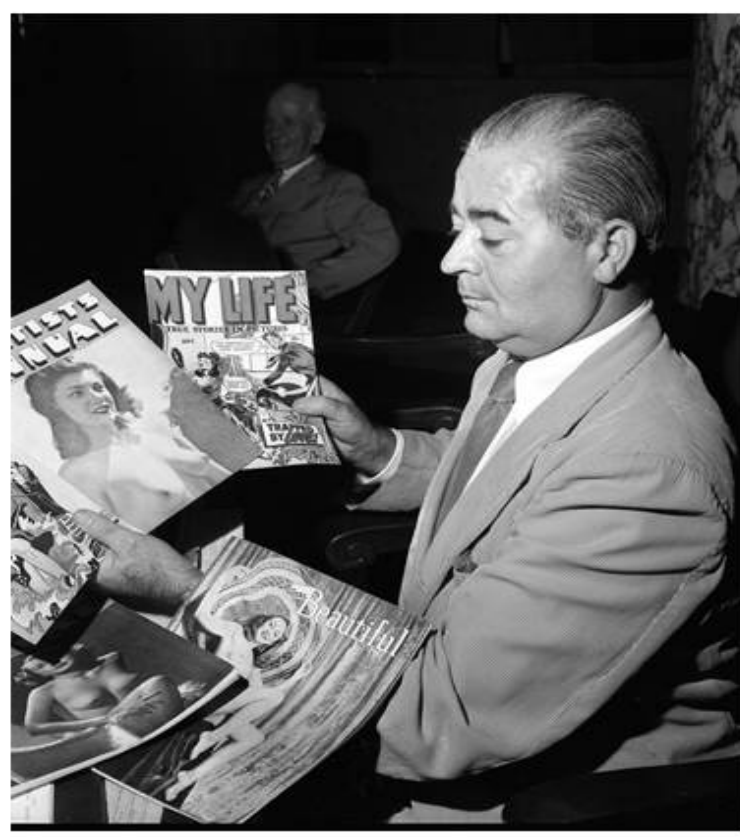

Fig. 13: El concejal de Los Ángeles Ed J. Davenport muestra ejemplos de revistas y cómics obscenos

Los medios propuestos con este fin resultaron bastante similares a lo largo y ancho de los Estados Unidos. Las medidas más severas entrañaban someter la publicación y distribución de cómics a licencias. Medida que fue considerada en Illinois, Washington o Lowell ${ }^{131}$ y que resultó adoptada finalmente sólo por Wisconsin Rapids ${ }^{132}$. Mucho más frecuente fue, sin embargo, la constitución de comités específicamente previstos para controlar la difusión de los cómics.

Las funciones de estos Comités resultan bastante heterogéneas según los municipios y Estados, pero pueden catalogarse en tres grupos. Así, en primer lugar, a algunas se les atribuyeron tareas de fomento, promoviendo la lectura entre los

129 "Betterment Suggestions Wanted By Mayor Vinson", Limestone Democrat (21 October , 1948), p. 1; "Ban on Comics Spreads, Cities Try Censorship", Valley Morning Star (29 October , 1948), p. 8 y Dothan Eagle (2-11-1948), p. 3; "Comic Book Ban Spreads, Report", Racine Journal Times (November 1, 1948), p. 19; "Ban on Comic Books Spreads To Many Cities", Kokomo Tribune (November 3, 1948), p. 9; "Comic Book Ban Spreads", Oakland Tribune (November 3, 1948), p. 68; "Ban On Comic Book Spreads", Beckley Raleigh Register (November 4, 1948), p. 22 (la misma noticia en Statesville Daily Record, 4-11-1948, p. 22); "Unfunny Funnies Ban Spreads to 50 Cities", Reno Evening Gazette (November 8, 1948), p. 5; "Ban on Comics Spreads in U. S.", Reno Evening Gazette (25 November , 1948), p. 18.

130 Tal fue el caso de la localidad californiana de Van Nuys, en cuyo pleno municipal se acordó que disponía de competencia para regular a través de una ordenanza municipal la venta de cómics. "Lewd Comic Book Ban to Council Soon", Van Nuys Valley News (July 15, 1954), p. 21.

131 Lane, Millicent: "Senate Group Scrutinizes Comic Book", Daily Journal-Gazette and Comercial-Star (March 31, 1949), p. 10; "To Test Comic Book Statute", Centralia Daily Chronicle (June 2, 1955), p. 19; "Unanimous Vote for City Manager to Name Censor", Lowell Sun (May 25, 1955), pp. 1, 26.

132 "Council", Wisconsin Rapids Daily Tribune (June 8, 1955), p. 15; "Council At Rapids Votes To License Comic Book Sales", Stevens Point Daily Journal (February 9, 1956), p. 15. En la prensa se señalaba que esta regulación era posiblemente un caso único en Estados Unidos: "Licensing of Comic Book Dealers Sought", Wisconsin Rapids Daily Tribune (February 8, 1956), p. 1. 
niños para que abandonasen de forma progresiva el consumo de cómics. Se trataba, pues, de la postura más proclive a minimizar la intervención pública y dirigida, por tanto, a adoptar medidas sustancialmente educativas, si bien su propia presencia retrajo a los vendedores, como sucedió en la localidad de Masillon, en Ohio ${ }^{133}$.

Un segundo grupo de medidas, de mayor intensidad, incidía ya directamente sobre el contenido de los cómics. En este punto, se encomendaba a los Comités estudiarlos, a raíz de lo cual en ocasiones se les facultaba también para elaborar códigos de contenidos, como en Bellingham y Memphis ${ }^{134}$. También es el llamativo caso de la localidad de St. Paul, en el Estado de Minnesota, cuya comisión redactó los “doce mandamientos" para los cómics. En su mayoría, éstos se hallaban redactados de forma positiva, a modo de obligaciones: se preveía que debian respetar las leyes morales de Dios, ensalzar los principios de la democracia americana recogidos en la Declaración de Independencia y en la Constitución, mostrar personajes que pudieran servir de modelo para la juventud y contribuir al desarrollo personal, presentar a la ley y la justicia con respeto, representar los actos criminales sujetos a procesos legales, instruir en el respeto por los grupos religiosos, raciales o nacionales, difundir la imagen de una vida familiar basada en la familia y el matrimonio, tratar con recato el sexo, utilizar un lenguaje aceptable y no vulgar, y anunciar sólo productos que contribuyesen al bienestar de la juventud. A modo de prohibiciones, los "doce mandamientos" del Comité de St. Paul preveían sustancialmente dos: la imposibilidad de mostrar actos criminales como si se fuesen atractivos o heroicos, y la proscripción de representar escenas desagradables ${ }^{135}$.

Algunos territorios, como Chicago ${ }^{136}$, Oklahoma City ${ }^{137}$, Tulsa ${ }^{138}$, St. Paul139 o Illinois ${ }^{140}$ fueron especialmente prolijos en este aspecto, refiriéndose a la obscenidad prohibida con los más variados adjetivos: obscenidad, lascivia, indecencia... En Connecticut se añadió la prohibición de mostrar "girlies" y mujeres desnudas o semidesnudas ${ }^{141}$; una regulación

133 "Committee On Books To Meet", Evening Independent (October 18, 1954), p. 2; Nowling, Jack: "Wholesalers Cut City's Trashy 'Comic' Supply, As Public Temper Rises", ibid.(October 20, 1954), p. 1.

134 "Fifty-four Comic Books Are Banned", Mount Pleasant News (31 August , 1948), p. 3; "Louisiana Briefs", Biloxi Daily Herald (November 5, 1954), p. 13.

135 "St. Paul Sets 12 Commandmenis For Comic Books", Mitchell Daily Republic (March $17,1949)$, p. 6.

136 "Comic Books", Portland Press Herald (December 9, 1948), p. 16.

137 "Hearing Set On Comics Ban", Evening Journal (July 29, 1954), p. 22.

138 "Objectionable Comics Are Banned By Tulsa", Great Bend Daily Tribune (September 30, 1954), p. 6. En realidad, la ordenanza preparada en Tulsa era una copia de la de Oklahoma City. "Tulsa Joins In Fight On Comics", Brownsville Herald (September 23, 1954), p. 16.

139 "St. Paul Puts Ban on Comic Book Sales", Austin Daily Herald (May 21, 1954), p. 5.

140 "Horror Book Sale Curbed", Southtown Economist (July 3, 1955), p. 1.

141 "Bans Comic Books", Albuquerque Journal (June 5, 1955), p. 37; "Senate Is Unanimous In Comic Book Vote", Bridgeport Post (June 4, 1955), p. 3. 
acordada a través de una Ley que aprobó la Asamblea estatal con apenas la oposición de dos representantes ${ }^{142}$ y que fue firmada sin oposición alguna por el Gobernador en el verano de $1955^{143}$.

En otros casos, las prohibiciones se orientaban en un sentido moral y religioso, vetando los cómics que pudieran considerarse inmorales (Gary, en Indiana, Oklahoma City, Maryland, Worthington o Oregon) ${ }^{144}$ o que hicieran atractivo el pecado (como en Jackson, Mississippi) ${ }^{145}$. Tales previsiones, aunque podian hallar también acomodo dentro de la legislación antiobscenidad, adolecian de un importante grado de indefinición que las ponía al borde mismo de la inconstitucionalidad.

La representación del horror y de la violencia, por su parte, también se hallaba entre los contenidos vetados en algunos Estados, pero, al igual que en el caso anterior, su escasa definición y la amplitud que implicaban resultaba dificil de compaginar con las exigencias constitucionales de seguridad juridica. No en balde tales prohibiciones podian alcanzar a historias de terror, como las de Edgar Allan Poe, o a los géneros policíaco y detectivesco, desde Arthur Conan Doyle hasta Agatha Christie. Para evitar al menos en parte estos resultados, algunos territorios mencionaron exclusiones legales expresas: por ejemplo, se mencionaba que las prohibiciones no alcanzarian a los hechos bíblicos o históricos.

Sin embargo, de todos los territorios que acordaron medidas anticómic, dos tuvieron especial relevancia, ya que marcaron la pauta que seguirian los demás: California y Nueva York. En el primero, Los Angeles City Council actuó como referente para otras ciudades ${ }^{146}$ al aprobar en 1948 una ordenanza municipal, a iniciativa del concejal Ed J. Davenport, que prohibía la venta a menores de dieciocho años de cómics que relatasen asesinatos, robos, hurtos, incendios provocados y asalto con armas, imponiendo una sanción de 500 dólares o seis meses de cárcel ${ }^{147}$.

142 "Assembly Curbs Comic Book Sales", Bridgeport Post (June 7, 1955), p. 8.

143 "Law Is Signed On Comic Books", Bridgeport Post (July 19, 1955), p. 6.

144 "Comic Books Curbed", Anderson Herald Bulletin (December 22, 1955), p. 16; "Hearing Set On Comics Ban", Evening Journal (July 29, 1954), p. 22; "Bill On Crime Comics Signed Into State Law", Cumberland Evening Times (April 29, 1955), p. 14; "Kennon Plan", Monroe News Star (May 10, 1954), p. 2; "Worthington Drive On Lewd Literature Meets Opposition", Winona Daily News (September 1, 1954), p. 19; "Ten New State Laws Become Effective During Week", Hillsboro Press Gazette (October 7, 1955), p. 7.

145 "Jackson Has New Comic Book Law", Biloxi Daily Herald (December 18, 1954), p. 1.

146 Schultz, Henry E.: "Censorship or Self Regulation?", Journal of Educational Sociology, vol. 23, núm. 4, 1949, p. 222. Esta postura la había anticipado en Schultz, Henry E.: "The Comics as Whipping Boy", Recreation, August 1949, p. 239.

147 "L. A. Council Joins Comic Book Fight", Bakersfield Californian (19 August , 1948), p. 29; "Supervisors Weigh Fate of Comics", Long Beach Press Telegram (19 September , 1948), p. 3; "Only Comedy in Comic Books, Supervisors Vote", Manitowoc Herald Times (22 September , 1948), p. 9; "LA Officials Rule Against "Comic" Books", Arizona Daily Sun (22 September , 1948), p. 1; Sheboygan Press (22-09-1948), p. 21; "Critics Hit Art In Comic Books", Indiana Evening Gazette (22 September , 1948), p. 2; "L. A. Puts Ban on Unfunny Comic Books", San Mateo Times (22 September , 1948), p. 9; "Los Angeles Prohibits Unfunny Comic Books", Alton Evening Telegraph (22 September , 1948), p. 14; "Comic Books Should Stick to Comedy, L. A. Board Rules", Jacksonville Daily Journal (23 September , 1948), p. 11; 


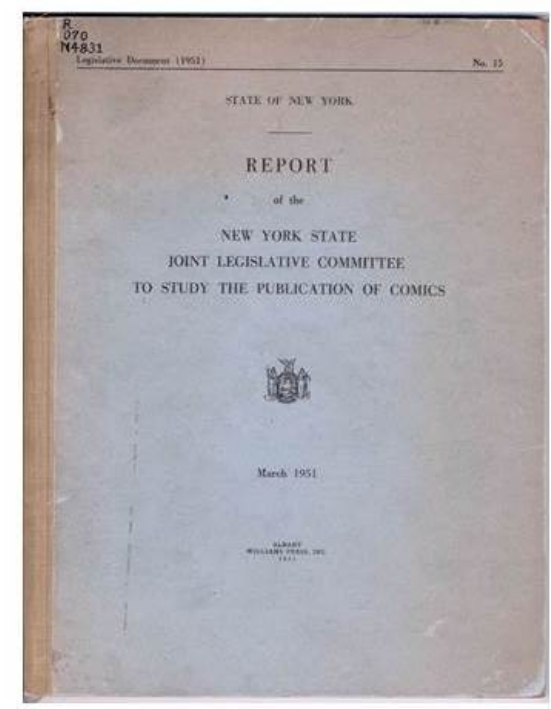

Fig. 14: Informe del Comité Legislativo de Nueva York sobre los cómics (1951)

debían prohibirse ${ }^{154}$.
Por su parte, New York se ha definido como un auténtico campo de batalla de la campaña legal anticómic entre $1948 \mathrm{y}$ 1955148. Muchos de los municipios comprendidos en el Estado de New York habían sido pioneros en la cruzada contra aquellas publicaciones: en 1948 el fiscal de distrito de Albany había prohibido la distribución de sesenta y dos cómics ${ }^{149}$; por esas mismas fechas en Utica se habia advertido a los vendedores la necesidad de mostrarse cooperativos y renunciar a la venta de crime comics ${ }^{150}$; en Cattaraugus County se habian empezado a examinar a través de la fiscalía los cómics que glorificaban el crimen, horror y sexo $^{151}$ y Oneida ${ }^{152}$, Salamanca ${ }^{153}$ y Watertown crearon comisiones para examinar los cómics o crear listas de aquellos que

Con estos precedentes, el Parlamento de Nueva York intentó hasta en dos ocasiones aprobar una ley especificamente dirigida a prohibir la distribución de cómics por su territorio, pero en ambos casos el Gobernador Dewey las vetó. Lejos de desanimarse, el Comité parlamentario neoyorkino volvió a proponer nuevas medidas legislativas en un informe de 1954155 , en el que, además, alertaba de la presencia de un nuevo género de cómic

"Board Wants Comic Books To Stay Funny", Biloxi Daily Herald (23 September , 1948), p. 13; "Ban Comic Books That Aren't Funny", Huronite And The Daily Plainsman (23 September , 1948), p. 3; "L. A. Comic Book Ban Couort Test Welcomed", Oakland Tribune (23 September , 1948), p. 5; "Declares Anti-Comic Book Law to Stand", Abilene Reporter News (24 September, 1948), p. 48; "Sale Of Crime Comics Banned", Evening Independent (22 October , 1948), p. 18; "Comics Outlawed", Montana Standard (22 October , 1948), p. 13; "Objectionable Books of Comics Disappear From Los Angeles Stands After New Law", The New York Times (October 4, 1948), p. 26.

148 Mitchell, Steven E.: Evil Harvest: Investigating the Comic Book, 1948-1955, Research Thesis, Master of Arts, Arkansas State University, Arkansas, 1982, p. 63. Esta extraordinaria tesis resulta de lectura muy recomendable por el exhaustivo y clarificador análisis de la campaña anticómic neoyorquina.

149 "Comic Books Studied By D.A.'s Office; Some Sales Banned", Olean Times Herald (December 2, 1948), p. 2.

150 "Ban Crime Comics", Olean Times Herald (November 6, 1948), p. 1.

151 "Comic Books Studied By D.A.'s Office; Some Sales Banned", Olean Times Herald (December 2, 1948), p. 2.

152 Olean Times Herald (10-11-1948), p. 20.

153 "Campaign On Comic Books In Salamanca", Warren Times Mirror (December 8, 1948), p. 5.

154 "Organization Will Curb Comics", Syracuse Herald Journal (December 17, 1948), p. 61.

155 Report of the New York State Joint Legislative Committee to Study the Publications of Comics, William Press, Albany, 1954, , pp. 39-48. "Obscene and Other Objectionable Comics Are Targets for a Series of Albany Bills", The New York Times (February 18, 1953), p. 21. 
especialmente dañino, el de romance, en cuyas portadas pululaban escenas de alto contenido sexual156. Así las cosas, el Comité insistía en adoptar restricciones a los cómics, sin que, a su parecer, ello supusiese violentar la libertad de prensa ya que

"seguramente los padres de nuestra Constitución no entendieron esas garantías como una licencia para que los editores irresponsables pudiesen contaminar las mentes y la moral de los niños en su propio beneficio"157.

Las propuestas del Comité se materializaron en tres leyes, una destinada a castigar la publicación de obras obscenas ${ }^{158}$, y otras dos a controlar su distribución ${ }^{159}$. Por lo que se refiere a la primera, se añadían expresamente los comic books entre las publicaciones obscenas cuya distribución podia resultar prohibida por el Tribunal Supremo del Estado a requerimiento de las autoridades. En cuanto a las otras dos normas, elevaban la pena por distribuir publicaciones obscenas de cincuenta a ciento cincuenta dólares. A diferencia de lo acontecido en anteriores ocasiones, en este caso las tres leyes propuestas no sólo fueron aprobadas por el Parlamento ${ }^{160}$, sino que también contaron con el beneplácito del gobernador Dewey ${ }^{161}$. Con esta nueva legislación operativa, en septiembre de ese mismo año el alcalde de New York, Robert F. Wagner, ordenó a los oficiales que emprendieran acciones contra los cómics violentos o eróticos que se vendiesen por la ciudad ${ }^{162}$.

\section{LA CORRECCIÓN JURISPRUDENCIAL (I): LOS LIMITES A LA LEGISLACIÓN CONTRA LAS PUBLICACIONES ESCABROSAS}

Los legisladores se habian mostrado muy activos a la hora de perseguir la literatura considerada "indecente" por los moralistas. Sin embargo, no siempre contaron con el respaldo de los jueces. De hecho, en plena campaña contra los pulp magazines, muchas de las demandas por obscenidad promovidas por las sociedades antivicio acabaron desestimadas, ya que por

156 Report of the New York State Joint Legislative Committee to Study the Publications of Comics, op. cit., p. 16.

157 Ibid., p. 32.

158 An Act to amend the code of criminal procedure, in relation to the publication of obscene literatura. Puede consultarse en el apéndice de ibid., p. 41.

159 An Act to amend the penal law, in relation to increasing fine on conviction of persons guilty of distributing obscene prints and articles y An Act to amend the penal law, in relation to distribution of indecent articles. En ibid., pp. 39, 41.

160 "Obscene Books Ban Pushed At Albany", The New York Times (March 4, 1953), p. 19.

161 Public Papers of Thomas E. Dewey Fifty-First Governor of the State of New York, State of New York, New York, 1954, pp. 306-307. "ObsceneComic, Other Pulps Now Face Law", Dunkirk Evening Observer (April 15, 1954), p. 1.

162 "NY Mayor Hits Bad Comic Books", Berkeley Daily Gazette (September 8, 1954), p. 5. 
ejemplo los jueces neoyorkinos generalmente sólo sancionaron los casos más evidentes de literatura hard core ${ }^{163}$.

Pero, más allá de esta autocontención judicial, los tribunales dieron un duro revés a la legislación moralista, declarándola en muchos casos inconstitucional. Bien es cierto que las primeras resoluciones, procedentes de Tribunales Superiores de los Estados, fueron favorables a las normas que pesaban sobre las publicaciones de temática criminal ${ }^{164}$. Así sucedió cuando el Tribunal Superior de Illinois (Harry L. Strohm v. The People of the State of Ilinois, Ill. S. Ct. 1896) enjuició la aplicación de una ley de 3 de Junio de 1889 ("An Act to suppress selling, lending, giving away or showing to any minor child any paper or publication principally devoted to illustrating or describing inmoral deeds") cuya sección primera impedía la distribución de publicaciones que contuviesen escabrosas narraciones referentes a actos criminales. El asunto se había suscitado tras ofrecer a un menor una publicación, The Sunday Sun, centrada en noticias sobre actividades delictivas. El Tribunal concluyó que para incurrir en el ilícito penal no resultaba preciso que la totalidad del periódico contuviese noticias criminales y que bastaba con que la descripción de esas noticias o hechos figurase principalmente en la publicación, ya fuese a través de imágenes, de texto, o de una combinación de ambas ${ }^{165}$. Pero en ningún caso el Tribunal de Illinois cuestionó la validez de la ley estatal.

Un segundo caso siguió unos derroteros igualmente favorables a la legislación restrictiva de publicaciones de temática criminal. En esta ocasión, lo que se cuestionaba era una ley del Estado de Connecticut de 1895 ("An Act relating to Obscene Literature")166. El Tribunal concluyó que "no existe un derecho constitucional a publicar cualquier hecho o suceso que pueda ser cierto". En su resolución, dejó claro que la definición de la ley -muy similar a la neoyorkina - "no viola ninguna provisión relativa a la libertad de prensa", ya que esta última no podía amparar abusos que pudieran afectar a la paz y seguridad estatales. El tribunal concluía la legitimidad del Estado para prohibir publicaciones que pudiesen causar un deterioro moral en la sociedad similar al que ocasionaban las consideradas obscenas (State v. McKee, 73 Conn. 18, 1900).

163 Sobre la falta de respaldo judicial de las campañas de Sumner y la progresivo disminución en las detenciones (de 184 en 1920, a 41 en 1925) véase Pringle, Henry F.: "Comstock The Less", The American Mercury, vol. X, núm. 37, January 1927, pp. 57-62.

164 En este sentido, se ha señalado que el debate sobre la libertad de expresión fue muy intenso en el ámbito de los tribunales estatales, frente a la creencia de que la construcción jurisprudencial de dicha libertad se ha debido sobre todo al Tribunal Supremo. Anderson, Alexis: "The Formative Period of First Amendment Theory, 1870-1915", American Journal of Legal History, núm. 24, 1980, p. 73.

165 Reports of Cases at Law in Chancery Argued and Determined in the Supreme Court of Mlinois, Isaac Newton Phillips, Bloomington, 1896, vol. 160, pp. 582-587.

166 Andrews, James P.: Cases Argued and Determined in the Supreme Court of Errors of the State of Connecticut (May, 1900-May 1901), The Banks Law Publishing Co., New York, vol. LXXIII, pp. 18-33. 
Las cosas parecian marchar bien, por tanto, para los propósitos de la campaña "libros limpios", pero no tardarian en sufrir un duro revés cuando la legislación contraria a las publicaciones de temática criminal se sometió al escrutinio del Tribunal Supremo de los Estados Unidos. Recordemos que desde 1884, el Estado de New York disponía en su Código Penal de un artículo por el que se prohibía la venta, exhibición o transmisión (así como la posesión con idénticos fines) de cualquier publicación -incluidas expresamente las revistas- "principalmente referida a noticias delictivas, informes policiales o narración de hechos delictivos, o que contenga imágenes e historias de hechos sangrientos, lascivos (lust) o criminales"167. Con posterioridad, la norma ampliaria los sujetos responsables, para alcanzar también a quienes imprimiesen, pusiesen en circulación o publicasen ese tipo de materiales ${ }^{168}$. Originariamente la ley había sido concebida para perseguir publicaciones como The National Police Gazette, creada en 1845 y que pretendía ser una crónica delictiva destinada al gran público, aunque el sensacionalismo -y la presencia de pin-ups-constituía el principal motivo de su éxito de ventas ${ }^{169}$.

En 1942 el Código Penal neoyorkino se aplicó con severidad contra Murray Winters, propietario de una pequeña librería en Broadway. Un miembro de la New York Society for the Supression of Vice entró en el establecimiento y adquirió el primer número (junio de 1940) de un "pulp" titulado Headquarters Detective (True Cases from the Police Blotter) ${ }^{170}$. Tras hojear la adquisición, salió de la tienda y alertó a la policía, que a no tardar se personó en la librería y procedió al arresto de Winters en aplicación del Código penal neoyorkino. El ejemplar en cuestión contenía escabrosas fotografias de asesinatos, en la línea de lo que sería habitual en la publicación, con imágenes que resultarían impactantes incluso a día de hoy ${ }^{171}$. Finalmente Winters fue condenado a cien dólares de multa, aunque la pena podría haber alcanzado los mil dólares e incluso privación de libertad entre diez días y un año. Así de severa era la norma.

167 Title X (Of Crimes Against the Person and against Public Decency and Good Morals), Chapter VII (Indecent exposures, obscene exhibitions, books and prints, and disorderly houses), Section 317.2 en The Penal Code of the State of New York. In force December 1, 1882 as amended by Laws of 1882, 1883, 884, 1885, Banks \& Brothers, New York, 1885, pp. 9697.

168 Section 1141.1. New York Penal Law, Consol. Laws, c. 40.

169 Mott, Frank Luther: A History of American Magazines. 1850-1865, Harvard University Press, Cambridge, 1938, pp. 325-327. Tampoco desmerecian en las ventas las "pin-ups" que figuraban en las páginas de la revista, y que la convertia en una "revista para hombres". Reel, Guy: National Police Gazette and the Making of the Modern American Man, 1879-1906, Palgrave McMillan, New York, 2006, pp. 3, 145-176.

170 Murley, Jean: The Rise of True Crime. 20th-Century Murder and American Popular Culture, Praeger, Westport, 2008, pp. 19-20; Wiecek, William M.: The Oliver Wendell Holmes Devise History of the Supreme Court of the United States, Cambridge University Press, New York, 2006, vol. XII: The Birth od the Modern Constitution. The United States Supreme Court, 1941-1953, p. 193.

171 Gajda, Amy: The First Amendment Bubble. How Privacy and Paparazzi Threaten a Free Press, Harvard University Press, Cambridge, 2015, pp. 24-25. 


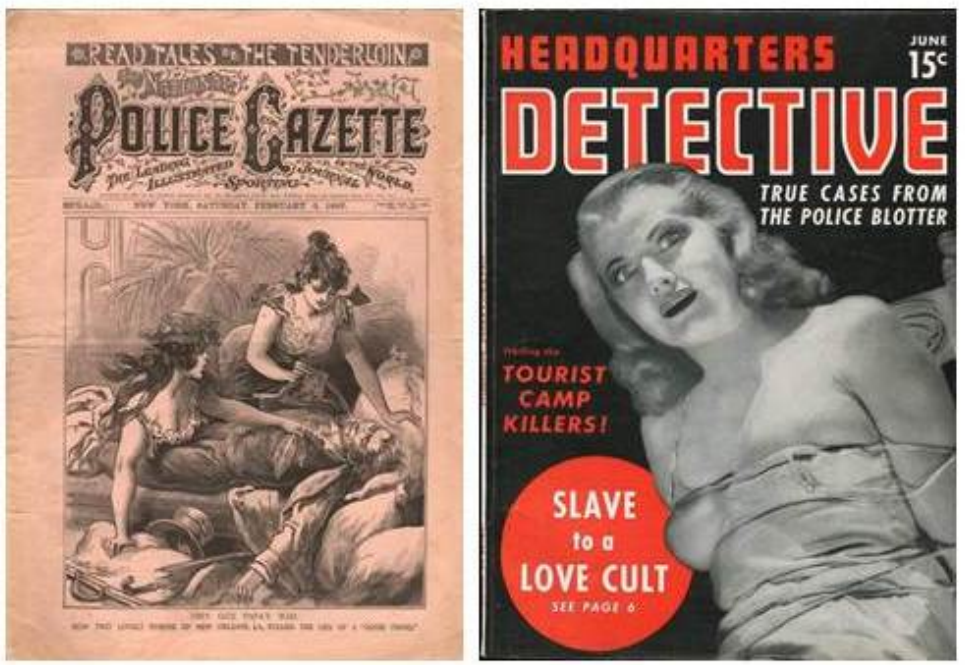

Fig. 15: Un ejemplar de "Police Gazette" y el primer número de "Headquarters Detective" que dio lugar al caso Winters v. New York
A pesar de que Winters no padeció todo el rigor que la ley penal podía alcanzar, no por ello se conformó con la sanción, recurriéndola ante el Tribunal de Apelaciones de New York que falló en su contra (People v. Winters, 294 N.Y. 545, 1945) ${ }^{172}$. En su resolución, el tribunal afirmaba que las publicaciones que habian causado el procesamiento de Murray Winters contenian exclusivamente historias e imágenes sobre crimenes sangrientos y depravados. En este sentido, aunque no se tratase de material de índole sexual, cabía calificarlo aun así como "indecente u obsceno", por cuanto servía como instrumento para incitar actos violentos. Se trataba, pues, de una interpretación extensiva de "obscenidad", en la que el tipo penal no venía identificado por su contenido sexual, sino por un elemento finalista cual era la capacidad para inducir comportamientos delictivos. Para determinar hasta qué punto cabía calificar de obscenas a estas publicaciones, el tribunal entendía que debía tomarse en consideración la conciencia social de cada momento, adoptando como referencia lo que al respecto pudieran opinar "hombres razonables". Y, en el caso de Headquarters Detective, el Tribunal no dudaba de que cualquiera que tuviese esa condición la consideraría como una publicación obscena. La sentencia apenas contó con el voto disidente de uno de los magistrados, precisamente el Presidente del Tribunal, Irving Lehman, quien consideró que la definición del tipo de publicaciones prohibidas resultaba excesivamente vago y, de resultas, devenía inconstitucional.

La sentencia condenatoria a Winters no resultaba excepcional si tenemos en cuenta que, como ya vimos, los Tribunales Superiores de los Estados habían fallado a menudo a favor de las leyes represivas. El caso, sin embargo, alcanzaría el Tribunal Supremo, donde, para su fortuna, Winters hallaria mejor suerte. Winters $v$. New York constituye el primer caso en el que el Tribunal Supremo se enfrentó explícitamente con el problema de la violencia en los mass media y su impacto en los niños ${ }^{173}$. En la resolución, el Tribunal avalaba la competencia de los Estados para considerar cierto

172 Cross, Leland F.: Reports of Cases Decided in the Court of Appeals of the State of New York, William Press, Albany, 1945, vol. 294, p. 545.

173 Krattenmaker, Thomas G. / Powe, L. A.: "Televised Violence: First Amendment Principles and Social Science Theory", Virginia Law Review, vol. 64, núm. 8, 1978, p. 1174; Heins, Marjorie: Not In Front of the Children. "Indecency", Censorship, and the Innocence of Youth, Rutgers University Press, New Brunswick, 2007, pp. 54-55. 
material como "objetable", impidiendo su circulación cuando se trataba de evitar un mal social como podia ser la delincuencia juvenil. Ahora bien, tales medidas legislativas se hallaban sujetas a limites constitucionales impuestos por la primera y cuarta enmiendas, y era este el punto débil de la legislación neoyorkina.

En primer lugar, el Tribunal daba un paso de gigante al dejar claro que las revistas -y por tanto también los cómics- se hallaban amparadas por la libertad de prensa reconocida en la primera enmienda. Ésta no sólo protegía la circulación de ideas -lo cual resultaría impracticable, ante la imposibilidad de determinar cuándo un escrito contenía o no "ideas"-, ni tampoco se circunscribía a tutelar publicaciones de las que se desprendiese algún tipo de utilidad social ${ }^{174}$. Cualquier publicación, y por tanto las meramente lúdicas también, se encontraba amparada por la libertad de prensa, por lo que el Tribunal negaba una concepción funcional del derecho fundamental.

Si una revista como Headquarters Detective se hallaba protegida por la libertad de prensa, sólo podia quedar excluida de esa tutela cuando existiese un motivo de orden público que lo hiciera necesario. Ahora bien, esa restricción debía sujetarse al due process of law, en particular al principio de certeza que alcanzaba su máxima intensidad cuando, como en el caso de la ley neoyorkina en liza, se trataba de un tipo penal. La ley penal debía fijar con concreción suficiente tanto los hechos punibles como la sanción aplicable, y era precisamente en el primero de estos elementos donde el Código neoyorkino fracasaba. No determinaba con suficiente claridad qué publicaciones resultaban realmente prohibidas, por lo cual se producía indefensión en el vendedor -en este caso personalizado en Murray Wintersque se veía imposibilitado para saber si los productos con los que comerciaba contrariaban la legislación vigente. $Y$ es que, frente a lo que había sostenido el Tribunal de Apelaciones, el Código Penal de New York no identificaba revistas como Headquarters Detective con "publicaciones obscenas", de modo que la definición de "obscenidad" -que contaba con una dilatada jurisprudencia- no sería aplicable a aquellas ${ }^{175}$. En consecuencia, el juez era quien quedaba legitimado, caso por caso, para determinar si una concreta publicación tenía un contenido violento que impulsase al crimen y, por tanto, resultaba prohibida por la ley. Una arbitrariedad inadmisible, sobre todo porque ni tan siquiera en esta definición "finalista" había concreción suficiente: impulsar un crimen no era un concepto técnico, como pudiera ser la inducción o la cooperación necesaria.

De resultas de todo lo cual, el Tribunal Supremo concluía que el artículo del Código Penal neoyorkino resultaba manifiestamente inconstitucional, ya que "un Estado no puede castigar a través de una

174 Esta teoría se reiteraría en Joseph Burstyn, Inc. v. Wilson (343 US 495, 1952).

175 En este sentido, se ha señalado que la sentencia implicitamente rechazaba una interpretación extensiva de "obscenidad" que pudiera incluir también a las publicaciones que narraban delitos. Berns, Walter: Freedom, Virtue and The First Amendment, Louisiana State University Press, Baton Rouge, 1957, p. 38. 
cláusula tan vaga". La cuarta enmienda había sido, en definitiva, el principal argumento para dar la razón a Winters ${ }^{176}$.

La sentencia contó, sin embargo, con el voto discrepante del juez Frankfurter, quien motivó su disconformidad con una larguísima argumentación; de hecho más extensa que la propia resolución del pleno ${ }^{177}$. Felix Frankfurter (1882-1965) había nacido en Viena en el seno de una familia judia, aunque había emigrado a Estados Unidos a los doce años. Criado desde su más tierna infancia en un ambiente intelectual, el juez nunca se olvidaba de mencionar a su tío quien, aparte de arqueólogo, era director de una gran biblioteca vienesa y dominaba varios idiomas ${ }^{178}$.

Estudiante más que destacado, ingresó en el Harvard Law School, institución por la que confesaba sentir un sentimiento cuasireligioso ${ }^{179}$. Finalizados sus estudios, trabajó para el fiscal neoyrokino Henry Stimson y, cuando éste fue designado Secretario de Guerra por el Presidente William Howard Taft, le sirvió como asistente, pasando entre 1913 y 1914 a servir para la Administración de Woodrow Wilson. Tras participar activamente en la fundación de la Ameridcan Civil Liberties Union, Frankfurter ingresó en 1921 en el Harvard Law School como profesor. Persona de estrictas convicciones jurídicas, llegaria a decir:

"me tomo el Derecho muy en serio, profundamente en serio, porque a pesar de lo frágil que es la razón, y lo limitado que resulta el Derecho en cuanto expresión del medio institucionalizado de la razón, constituye no obstante todo lo que tenemos entre nosotros y la tiranía de la mera voluntad y la crueldad de los sentimientos desenfrenados e indisciplinados" 180 .

Esa fe en la función social del Derecho justifica la dura crítica que vertió sobre el juicio a los anarquistas Sacco y Vanzetti, y en el que el jurista de origen austriaco consideraba que no se habian observado las debidas

176 De hecho, un sector de la doctrina considera que la jurisprudencia del Supremo sobre la "indefinición inconstitucional" (es decir, la declaración de inconstitucionalidad de una norma por su excesiva vaguedad) ha sido construida para crear una zona de protección añadida para determinados derechos fundamentales, entre los que se encuentra, por supuesto, la libertad de prensa. En este sentido, se ha achacado a sentencias como Winters v. New York el empleo por el propio Tribunal Supremo de un lenguaje conscientemente vago, en el que la acusación de "indefinición" en la norma no se explica suficientemente. De hecho, se ha observado también cómo son fueron precisamente los nuevos delitos los que más debieron sujetarse al control de "indefinición" por parte del Tribunal Supremo. Amsterdam, Anthony G.: "The Void-for-Vagueness Doctrine in the Supreme Court", University of Pennsylvania Law Review, vol. 109, núm. 1, 1960, pp. 75, 82, 84, 99. Merece la pena destacar que este espléndido trabajo fue elaborado por Anthony G. Amsterdam cuando aún era un estudiante de Derecho y llegó a convertirse en uno de los más citados de las revistas legales estadounidenses. Newman, Roger K.: The Yale Biographical Dictionary of American Law, Yale University Press, New Haven, 2009, p. 12.

177 En su diario Frankfurter menciona el caso, pero sin pronunciarse sobre él. Lash, Joseph L.: From the Diaries of Felix Frankfurter, W. W. Norton and Company, New York, 1975, (Monday, November 25, 1946), p. 307.

178 Phillips, Harlan B.: Felix Frankfurter Reminisces. An intimate portrait as recorded in talks with Dr. Harlan B. Philips, Reynal and Company, New York, 1960, p. 5.

179 Ibid., p. 19.

180 Ibid., p. 189. 
garantías procesales y había influido negativamente la condición de inmigrantes de los $\operatorname{reos}^{181}$. De hecho, en 1931 haria acto de presencia en un homenaje a Sacco y Vanzetti celebrado en Boston ${ }^{182}$, y ello a pesar de que ideológicamente se hallaba muy distante de lo que aquellos representaban.

Tras rechazar un puesto en la Supreme Judicial Court of Massachusetts, no pudo hacer lo propio en 1938, cuando fue designado por Franklin Delano Roosevelt como magistrado del Tribunal Supremo, cargo que ejerció durante veintitrés años. Llegaba así al puesto que ocupase también Oliver Wendell Holmes, una figura por la que Frankfurter sentía una honda admiración y de quien decía que "poseía esas cualidades de genio personal en mayor medida que ningún otro magistrado en la historia del Tribunal Supremo"183.

Siendo uno de los magistrados más reputados del Tribunal Supremo, la opinión de Frankfurter en Winters $v$. New York tenía un peso trascendente, $\mathrm{y}$ de hecho sus argumentos fueron en los años sucesivos casi tan citados como la propia sentencia ${ }^{184}$. Frankfurter manifestaba no entender por qué el Tribunal Supremo consideraba que una imagen publicada en una revista

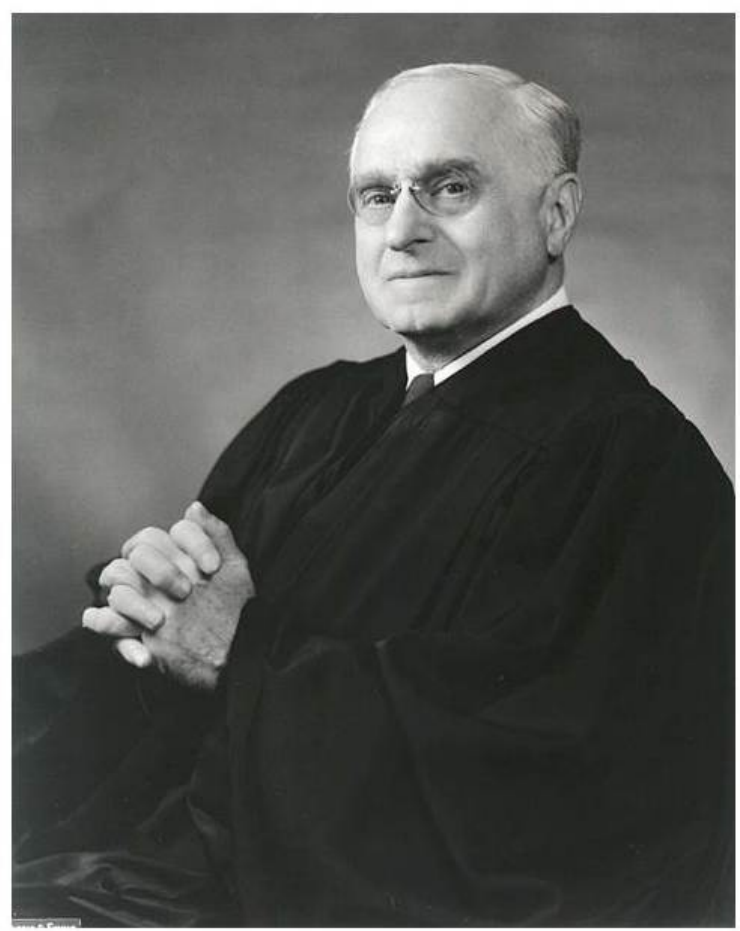

Fig. 16: El juez Felix Frankfurter podía ser constitucionalmente prohibida cuando resultaba obscena, y sin embargo no se admitía que pudiese igualmente ser vetada cuando incitaba a la violencia y al crimen. Había, por tanto, un trato diferencial entre la legislación antiobscenidad -cuya constitucionalidad no se discutía- y la normativa elaborada para punir las publicaciones que contuviesen imágenes escabrosas y violentas.

Esta última normativa también servía para atajar un mal social y de hecho respondia al justificable intento de las autoridades para prevenir lo que Frankfurter consideraba como "el más persistente, intrincado, elusivo $\mathrm{y}$ demandado de todos los problemas de la sociedad": el problema de la criminalidad y, más en particular, el

181 Frankfurter, Felix: "The Case of Sacco and Vanzetti", The Atlantic Monthly, March, 1927, pp. 409-432; Frankfurter, Felix: Case of Sacco and Vanzetti a Critical Analysis for Lawyers and Laymen, Peter Smith Pub Inc . Gloucester, 1973,

182 Avrich, Paul: Anarchist Voices. An Oral History of Anarchism in America, AK Press, Edinburgh, 2005, p. 133;

183 Frankfurter, Felix: Mr. Justice Holmes and the Supreme Court, The Belknap Press of Harvard University Press, Cambridge, 1961, p. 46.

184 Véase a modo de ejemplo el comentario de la sentencia de Bodle, John F.: "Recent Decisions", Notre Dame Law Review, vol. 23, núm. 4, 1948, pp. 602-604, donde se dedica tanto espacio al voto particular (con el que el autor parece coincidir más) que a la decisión de la mayoría. 
de la delincuencia juvenil. En el legítimo ejercicio de su politica anticriminal, New York estaba capacitado para tipificar como delito también la incitación al crimen, y en este sentido Frankfurter compartía con la campaña anticómic la idea de que la presencia de imágenes violentas en las revistas resultaba, en sí misma, una incitación a conductas criminales. Empleando los mismos recursos que tanto gustarian a Wertham, el juez citaba diversos casos reales -algunos de parajes tan lejanos como Austrialia- en los que los jueces habian determinado que conductas criminales perpetradas por menores de edad respondian a la imitación de lecturas previas.

Así pues, las revistas que contenian imágenes que pudieran incitar a la comisión de delitos podian ser constitucionalmente prohibidas por los Estados, en uso de su competencia para prevenir la criminalidad. Bien es cierto, como alegaba el Tribunal Supremo, que esa legislación debía respetar el due process of law, pero Frankfurter entendia que el pleno erraba a la hora de ponderar el alcance de la cuarta enmienda constitucional. La "falta de certeza" que el Tribunal utilizaba como argumento para declarar la inconstitucionalidad del Código Penal neoyorkino era en sí misma un concepto indeterminado que en todo caso no debía identificarse con una certeza absoluta a la hora de definir los términos del tipo penal. Así, se preguntaba retóricamente el pertinaz magistrado:

\begin{abstract}
“¿Acaso debería el Parlamento de New York enumerar por su nombre las publicaciones que a su juicio 'incitan delitos violentos y depravados'? ¿Debería mencionar en detalle los ingredientes de las historias o imágenes que entrañan esa ‘incitación'? ¿Qué hay en las leyes condenadas que deje en las personas en una oscuridad tal que les impida saber qué quiere decirse por publicaciones que abusan de 'hechos sangrientos, criminales o lascivos' de modo que 'inciten delitos violentos o depravados'?”
\end{abstract}

La falta de certeza no se hallaba, pues, en los términos de la ley, puesto que esta definía suficientemente las conductas infractoras y la sanción o, lo que es lo mismo, cumplía con el principio de legalidad penal y, por tanto, con la cuarta enmienda. La falta de certeza, en su caso, se hallaba en el momento de aplicar un estándar de conducta aplicable con generalidad a las muy distintas circunstancias que surgirian en aplicación de la ley, pero tal problema era un elemento consustancial a la actividad judicial que en ningún caso entrañaba violación del due process of law ${ }^{185}$. La certeza legal era suficiente como para no confundir el contenido de Headquerters Detective -manifiestamente incitador de delincuencia- con párrafos indudablemente violentos que podian contener desde Hamlet hasta las obras de Conan Doyle y que claramente quedaban exentos de la aplicación de la ley.

En su reprimenda, Frankfurter concluía que la decisión del Tribunal Supremo no sólo echaba por tierra la ley de New York, sino también más de una veintena de disposiciones similares de otros Estados ${ }^{186}$ (¡como si la

185 Sobre la interpretación de Frankfurter del "due process of law" véase Urofsky, Melvin I.: Felix Frankfurter. Judicial Restrain and Individual Liberties, Twayne Publishers, Boston, 1991, pp. 148-164, en particular p. 152.

186 Concretamente las de Connecticut (1930), Illinois (1889), Iowa (1946), Kansas (1935), Kentucky (1935), Maine (1944); Maryland (1933), Massachusetts (1933); Michigan (1938), 
cantidad de leyes afectadas importase!). Algo que contravenía lo que, al parecer de Frankfurter, constituía la esencia del poder judicial: la autocontención ${ }^{187}$, una creencia que le granjeó entre muchos la fama de juez conservador ${ }^{188}$. Pero, más aún, no se trataba sólo de que la decisión del tribunal cercenase las competencias de los Estados en materia de prevención de la delincuencia juvenil, sino que además impediría cualquier tentativa incluso a nivel federal: "una decisión como ésta -afirmaba apocaliptico- supone un momento destructivo que va mucho más allá de las leyes de New York y de otros Estados directamente implicados", al punto de que afectaria a las futuras decisiones que en materia de politica legislativa podrian adoptar los Estados, temerosos en lo sucesivo de incurrir en inconstitucionalidad.

En realidad, la postura de Felix Frankfurter tenía no poco de vaticinio. La suya fue una prognosis que el tiempo no se demoró en demostrar. Y es que, ciertamente, los defensores de los cómics y, en general, los vindicadores de una interpretación extensiva de la libertad de prensa, enarbolaron Winters $v$. New York como estandarte para abanderar su postura. No resulta pues exagerado afirmar que de hecho la sentencia sirvió de muro de contención frente a las pretensiones legislativas que afectaban a los cómics. Incrementó los estándares de definición de los tipos penales -de modo que las leyes y ordenanzas intentaron definir con mayor precisión qué publicaciones se prohibian-, cuando no actuó de forma disuasoria para Estados y municipios que tenían interés en legislar sobre el asunto, pero no lo hacian, temerosos de incurrir en inconstitucionalidad. De hecho, la decisión del gobernador neoyorkino Thomas E. Dewey de vetar la legislación estatal sobre cómics promovida por el Joint Committee parlamentario respondió precisamente al temor infundido por la citada sentencia, según vimos.

Aquellas localidades que, aun así, intentaron aprobar normativa anticómic definiendo con mayor claridad el tipo penal, a fin de ajustarse a Winters $v$. New York, no lo tuvieron fácil. El primero en sufrirlo fue la ciudad de Los Angeles. En 1948 -es decir, coincidiendo con Winters $v$. New Yorkhabía aprobado la ordenanza 6633 a iniciativa del concejal Ed J. Davenport, por la que se condenaba con hasta quinientos dólares o seis meses de cárcel a quien vendiera a menores de dieciocho años cómics que narrasen asesinatos, robos, hurtos, incendios provocados $\mathrm{y}$ asalto con armas (Secciones II y V). La norma señalaba expresamente que "la lectura de estos cómics ha inducido a muchos niños a la comisión de delitos" (Sección I.e), imputándoles a editores y distribuidores, por consiguiente, una participación necesaria en la actividad criminal.

Ciertamente, la concreción del articulado era bastante mayor que la de la ley neoyorkina, ya que señalaba exactamente qué crimenes no podían

Minnesota (1945); Missouri (1939); Nebraska (1943); New York (1944); North Dakota (1943); Ohio (1940); Oregon (1940); Pennsylvania (1887); Washington (1932); Wisconsin (1945).

187 Urofsky, Melvin I., Felix Frankfurter. Judicial Restrain and Individual Liberties, op. cit., , p. 80.

188 Mendelson, Wallace (edit.): Felix Frankfurter. A Tribute, Reynal and Company, New York, 1964, p. 120. 
figurar en un cómic. No pareció bastarle, sin embargo, al Tribunal Supremo de California que, tras una demanda interpuesta por varios distribuidores, declaró inconstitucional la ordenanza a la luz tanto de las enmiendas primera y decimocuarta de la Constitución de 1787, como del art. I-9 de la propia Constitución californiana ${ }^{189}$ (Katzev v. County of Los Angeles, 52 Cal.2d 360, 1959). La inconstitucionalidad de la ordenanza derivaba, en primer lugar, del tratamiento diferenciado, y de resultas discriminatorio, que confería a los cómics en relación con otro tipo de publicaciones en los que también se explicitaban conductas delictivas. En este sentido, la sentencia desestimaba las pretensiones de "criminalizar el medio" por la que habian abogado desde los años cuarenta muchos de los promotores de la campaña anti-cómic. La sentencia, en este punto y como no podía ser de otra forma, coincidia con Winters $v$. New York al amparar a los cómics bajo el paraguas de la libertad de prensa.

Pero, más allá de la discriminación a los cómics, el Tribunal Supremo de California apreciaría un segundo factor de inconstitucionalidad: la atribución a aquellas revistas de una capacidad inductiva al delito. Como toda medida limitadora de las libertades de expresión y prensa, esta potencial peligrosidad que se atribuía a los cómics debía demostrarse a través del test del "clear and present danger", establecido por el Tribunal Supremo a raíz de la Sediction Act (1798)190 en 1919 (Schenck v. United States, 249 U.S. 47, 1919) con la oposición del mítico juez Oliver Wendell Holmes (Abrams v. United States, 250 U.S. 616, 1919). De conformidad con este estándar, sólo resultaría posible limitar las citadas libertades cuando se apreciara (a) una intención específica por parte del sujeto que hubiera vertido las expresiones; (b) la gravedad del mal ocasionado con ellas y (c) que el peligro resultara claro y eminente. En definitiva, se trataba de un test para ponderar la proporcionalidad de medidas limitadoras de derechos fundamentales ${ }^{191}$; test que, si bien había decaido en la jurisprudencia constitucional durante los años veinte y treinta, habia recuperado relevancia en los años cuarenta (Thomas v. Collins, 323 U.S. 516, 1945).

Consciente de esta circunstancia, el Ayuntamiento de Los Ángeles se había anticipado, y en la ordenanza se indicaba que

189 En su redacción original señalaba "Todo ciudadano es libre para hablar, escribir y publicar sus sentimientos, sobre cualesquiera materias, siendo responsable del abuso de tal derecho; y no podrá aprobarse ninguna ley que restringa o reduzca las libertades de expresión o imprenta (...)". Constitution of California (1849), en The Statutes of California, passed at the Twnety-Third Session of the Legislature, 1880, State Office, Sacramento, 1880, págs. XXIII-XXIV.

190 Sobre este punto me remito por todos a Arias Castaño, Abel: "La Sedition Act de 1798 y el libelo sedicioso: la criminalización de la libertad de expresión", Historia Constitucional, núm. 10, 2009, pp. 297-321 y Arias Castaño, Abel: Clear and Present Danger Test. La libertad de expresión en los limites de la democracia, Doctor en Derecho, Universidad de Oviedo, Oviedo, 2015, en especial pp. 279-298 donde califica la tesis sobre el "clear and present danger" dominante en la etapa en cuestión como "modelo militante". En él, la claridad e inminencia del peligro (exigencia en el modelo construido originariamente por los jueces Holmes y Brandeis) se sustituiria por la probabilidad (p. 289).

191 Sobre los limites de los derechos y su adecuación al principio de proporcionalidad vid. Carlos Bernal Pulido, El principio de proporcionalidad y los derechos fundamentales, Centro de Estudios Políticos y Constitucionales, Madrid, 2007, $3^{\mathrm{a}}$ ed. 
"el Consejo de Supervisores [de la ciudad de los Ángeles] entiende que existe (...) un peligro claro y presente (clear and present danger) de que la venta y circulación continuadas de cómics sobre crímenes en el área extramunicipal de Los Ángeles incite a los niños a cometer crímenes o a intentar cometerlos, e inculque a muchos de ellos el deseo de participar en actividades delictivas" (Sección I.g).

Sin embargo, y a pesar de esta afirmación, el Tribunal Supremo de California estimó que no se había demostrado suficientemente esta relación causal, de modo que la medida restrictiva no superaba el test de proporcionalidad.

Otro caso, menos conocido pero muy significativo, fue resuelto por el Tribunal de Apelaciones de Maryland (Police Commissioner of Baltimore City et al. v. Siegel Entreprises Inc., 223 Md. 110, 1960) a partir de la demanda interpuesta por un librero, quien solicitó la declaración de inconstitucionalidad de la Crime Comic Books Act of Maryland (Art. 27, Sections 420-425, Code 1957, según reforma de 1959) que prohibía la venta, exhibición o anuncio de publicaciones obscenas o que contuviesen noticias o imágenes de hechos criminales o sangrientos. El Tribunal dio la razón al demandante y declaró inconstitucional la norma por considerarla excesivamente vaga, según el parámetro impuesto por la ya citada sentencia Winters $v$. New York. Sin embargo, interesa señalar otro razonamiento del Tribunal que suponía un respaldo adicional para los crime comics $^{192}$. Tras reconocer que los poderes públicos tenian facultad para adoptar medidas tendentes a minimizar los incentivos al delito, el Tribunal de Maryland reconoció, sin embargo, que "el derecho de los jóvenes a leer lo que desean, dentro de los límites de lo permisible según la acción estatal o federal, no sólo es vital para ellos, sino también para toda la ciudadanía". El hecho de que ciertas publicaciones pudiesen resultar constitucionalmente vedadas a los menores "no entraña el derecho a silenciar a jóvenes o mayores hechos o acontecimientos aunque sean desagradables, perturbadores o violentos".

\section{LA CORRECCIÓN JURISPRUDENCIAL (II): LOS LÍMITES A LA LEGISLACIÓN CONTRA LAS PUBLICACIONES OBSCENAS}

Este acervo jurisprudencial hacía dificil la adopción de medidas legales ad hoc que restringiesen la producción y venta de publicaciones consideradas inmorales por su representación escabrosa de la criminalidad. Pero cabía otra alternativa a la que apelaron numerosas localidades: la legislación antiobscenidad. A su favor tenía el factor de que ésta, a diferencia de las normas orientadas a prohibir publicaciones que refiriesen hechos criminales, contaba con un respaldo jurisprudencial que se remontaba a finales del siglo XIX ${ }^{193}$. De hecho, las propias normas antiobscenidad

192 Pritchard, John F.: "Constitutional Law: Obscenity. Children's Film Classification Statute Held Constitutional", California Law Review, vol. 55, núm. 3, 1967, p. 929.

193 El caso más antiguo en Estados Unidos parece haber sido el de Commonwealth $v$. Sharpless, fallado en 1815 (2 Sergeant and Rawle 91, 1815). Los Tribunales estatales habian admitido ya desde finales del XIX expresamente la legislación antiobscenidad, admitiendo por ejemplo su legitimidad para evitar la corrupción de la moral de los jóvenes (In re Banks, 56 Kan. 242, 1895). 
gozaban de amplia tradición en Estados Unidos ${ }^{194}$, lo cual era ya un aval sobre su presunta constitucionalidad. En contra, sin embargo, pesaba el hecho de que esa legislación se habia construido sustancialmente para hacer frente a publicaciones de contenido sexual, de modo que, aunque pudieran alcanzar a los cómics con mayor carga erótica (desde luego las Biblias de Tijuana), carecian en principio de capacidad para erradicar otros contenidos nocivos que se achacaban a los cómics, como la violencia, el terror, el racismo o la hipotética inducción delictiva. La única posibilidad, en este caso, era ampliar, a través de un artificio, el concepto de "obscenidad", a fin de que comprendiese ese otro tipo de contenidos considerados igualmente dañinos.

A pesar de este problema, acudir a la legislación antiobscenidad tenía unas ventajas jurídicas evidentes que permitian sortear las exigencias impuestas en Katzev $v$. County of Los Angeles. Por una parte, puesto que aquella normativa no se refería uti singulis a los cómics, sino a toda suerte de publicaciones, no cabía apreciar regulación discriminatoria; por otra, las autoridades no necesitaban justificar el "clear and present danger", puesto que el Tribunal Supremo habia establecido que las expresiones obscenas no formaban parte de la libertad de expresión y prensa (Roth $v$. United States, 354, U.S. 476, 1957).

Este último punto es de extrema importancia para entender la argumentación del Tribunal Supremo. El test de "clear and present danger" sólo se aplicaba cuando se introducian medidas limitativas de las mencionadas libertades, es decir, cuando se creaban "limites externos" que constitucionalmente no se hallaban previstos. Pero si la obscenidad no formaba parte de la libertad de expresión, prohibir expresiones o publicaciones obscenas no entrañaba en sí mismo una medida limitadora del derecho. De resultas, no habiendo medida limitadora alguna, tampoco resultaba preciso demostrar la existencia de un "clear and present danger"195.

Ahora bien, el hecho de que las expresiones obscenas quedasen al margen de las libertades de la primera enmienda obligaba a determinar con precisión qué se entendía por obscenidad ya que, de lo contrario, podrían estar delimitándose inadecuadamente aquellas libertades (Marcus $v$. Search Warrant, 367 U.S. 717, 1961). Y determinar qué era la obscenidad resultaba un asunto polémico que habia intentado clarificarse normativa, jurisprudencial y doctrinalmente.

En términos jurisprudenciales hasta 1957 (es decir, hasta la sentencia Roth $v$. United States que más tarde examinaremos) la determinación de qué

194 Aparte del common law, en el ámbito federal ya en 1842 se prohibió la importación de materiales obscenos, y en 1865 su distribución por vía postal.

195 No obstante, el Tribunal Supremo mostraba cierta inconsistencia en este punto. Y es que, habiendo reconocido que la primera enmienda protegia también el derecho a decidir qué leer, el Tribunal concluía que un adulto tenía derecho constitucional a leer también publicaciones obscenas, de modo que éstas sólo podian restringirse a menores. De ser así, no queda más remedio que entender que las publicaciones obscenas forman parte del contenido subjetivo de la libertad de expresión, de modo que si se excluyen de él, habrá de ser a través de un límite externo. 
debía entenderse por obscenidad seguía las pautas establecidas por un caso de common law resuelto en Gran Bretaña en aplicación de la Obscene Publications Act (1857). El caso en cuestión, Regina v. Hicklin (L.R. 3 Q.B 360, 1868), forjó el denominado "Hicklin test" en virtud del cual se consideraba que una expresión o publicación resultaba obscena

"si la materia considerada como obscena tiende a depravar o corromper a aquellos sujetos cuyas mentes son permeables a tales influencias inmorales, y en cuyas manos pueda caer una publicación de este tipo"196.

La definición, aunque desafortunada, se convirtió durante décadas en la guía de los tribunales estadounidenses y británicos a la hora de aplicar estándares referentes a publicaciones obscenas ${ }^{197}$.
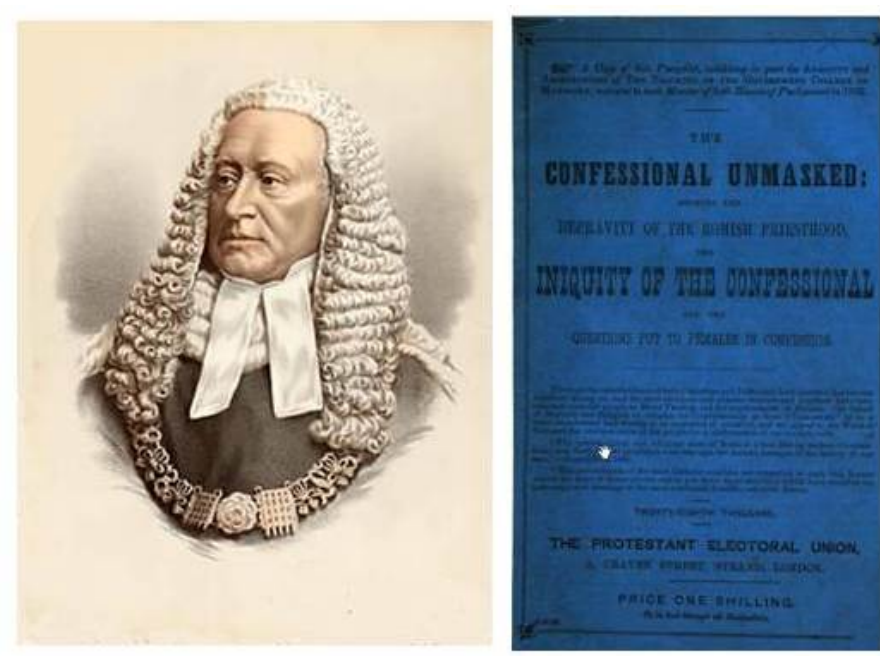

Fig. 17: Alexander Cockburn y la obra que dio lugar a la formulación del "Hicklin test" (1868)

E1 "Hicklin test", dictado por el juez Alexander Cockburn, comprendía tres elementos intrínsecamente ligados que permitian determinar cuándo una publicación resultaba obscena: los efectos que ocasionaba ("depravar o corromper"), los sujetos a los que afectaba (personas influenciables) y la cantidad de contenidos que debía incluir (bastaria con que parte de la obra resultase obscena). El primero de estos elementos que podríamos llamar "causal"- era precisamente el que confería una dimensión sexual al concepto de obscenidad $^{198}$. Lejos de definirse ésta de forma abstracta, la tendencia desde Regina $v$. Hicklin fue delimitarla por un principio de causalidad: su capacidad para ocasionar una reacción psíquica sexual en el lector. Así se observa en la primera aplicación del Hicklin test en una sentencia dictada en

\footnotetext{
196 Ver también Dysart v. United Status (272 U.S. 655, 1926).

197 Murphy, Terrence J.: Censorship: Government and Obscenity, Helicon, Baltimore, 1963, p. 42.

198 Este factor fue criticado a mediados de los años cincuenta por parte de la doctrina, que consideraba que los tribunales se empecinaban en atender exclusivamente al efecto que ocasionaba la obra obscena, ya fuese sobre la mente ya sobre el comportamiento del lector. Lockhart, William B. / McClure, Robert C.: "Obscenity in the Courts", Law and Contemporary Problems, vol. 20, núm. 4, 1955, p. 590. Por su parte, uno de los más destacados expertos en la libertad de prensa, Theodore Schroeder, decía echar de menos un test jurisprudencial sobre obscenidad que atendiese de forma objetiva a las cualidades literarias. Schroeder, Theodore, "Obscene" Literature and Constitutional Law, op. cit., p. 242. Precisamente a tenor de esta crítica surgieron algunas propuestas de definición de la obscenidad que trataban de prescindir del elemento causal. Tal es el caso de la definición ofrecida, por ejemplo, por Harry M. Clor, al considerarla como aquella representación del ser humano que lo deshumaniza, ofreciendo de él una imagen degradante. Clor, Harry M.: Obscenity and Public Morality. Censorship in a Liberal Society, The University of Chicago Press, Chicago, 1969, pp. 234 y 242.
} 
suelo estadounidense, en 1879, a raíz de una demanda interpuesta por Anthony Comstock contra un libro titulado "Cupid's Yokes, or The Binding Forces of Conjugal Life". En la sentencia, dictada por un tribunal de New York, la obscenidad dependia de la capacidad que tenian algunos pasajes del libro para sugerir "pensamientos impuros y libidinosos entre los jóvenes e inexpertos"199 (United States $v$. Bennett, 17 Blatchf. 357, 1879). Veinte años más tarde, en Joseph R. Dunlop $v$. United States (165 US 486, 1897) se reiteraba la idea causal en la obscenidad, ya que ésta debía tener por objetivo el promover propósitos impuros ${ }^{200}$. Y en el primer tercio del siglo XX, en una de las sentencias capitales, nacida a raíz del intento de importar el Ulysses de James Joyce a suelo norteamericano, seguía manteniéndose la imagen de la obscenidad como instrumento para excitar impulsos sexuales (United States $v$. One Book Called "Ulysses", 72 F. 2d 705, 1934)201. Pero en todas estas sentencias se afirmaba, además, que -tal y como se había fijado en Regina $v$. Hicklin- esa pulsión sexual debía tener un efecto corruptor para la moral. Esa circunstancia hacia que el peligro de las publicaciones obscenas trascendiera al individuo lector, pudiendo ocasionar una depravación de los estándares sociales de moralidad.

Y aquí era cuando entraba en juego la concreción de los sujetos a los que una publicación podia "depravar"; elemento clave para saber si ésta era auténticamente obscena. Como hemos visto, el Hicklin test definia la obscenidad a partir de aquellos sujetos que eran incapaces de un autocontrol, entre los que se incluían niños, mujeres o integrantes de la clase trabajadora ${ }^{202}$. En 1889, en United States $v$. Clarke (38, Fed. 732, 1889) se sostenía esa misma idea, considerando que el sujeto protegido, a partir del cual determinar si una publicación era obscena, eran las personas inmaduras, jóvenes, ignorantes o con acentuadas inclinaciones sexuales.

Desde luego, esta idea de obscenidad permitía fácilmente restringir cualesquiera lecturas, y obviamente también los cómics. Bastaba con considerar que una publicación resultaba excitante sexualmente y que depravaba en términos morales a un menor de edad para que le resultase aplicable la legislación antiobscenidad. Puesto que el estándar para apreciar esa obscenidad era la psique de una persona menos desarrollada psicológicamente -y de resultas más aprensiva-, el umbral de tolerancia hacia la literatura con contenido sexual resultaba tan recortado que también el público adulto tendría que conformarse con lecturas aptas para todos los públicos. Y es que, en la definición del Hicklin test, no se tomaba como referencia ni tan siquiera la "audiencia probable", es decir, el público al que

199 Riggs, Robert E.: Corrupted by Power. The Supreme Court and the Constitution, iUniverse, New York, 2004, pp. 151-153. En esta sentencia se afirmaba que una obra era obscena si así de percibía en "cualquier parte sustancial" de ella.

200 También, un año antes, en Swearingen $v$. United States (1611 US 446, 1896), donde la obscenidad se conectaba con la "impureza sexual". El lenguaje vulgar, por ejemplo, aun ofensivo no caería dentro de la definición legal de obscenidad.

201 La misma idea la sostuvo ese año el Tribunal Supremo de New York en People v. Berg (272 N.Y. supp. 586, 1934).

202 Heath, Deana: Purifying Empire. Obscenity and the Politics of Moral Regulation in Britain, India and Australia, Cambridge University Press, New York, 2010, p. 51-52. 
habitualmente se dirigía la obra en cuestión, ya que tenía en cuenta a cualquiera "en cuyas manos pueda caer una publicación de este tipo". Obviamente resultaba imposible evitar que un menor pudiera acceder a lecturas inapropiadas, y eso bastaría para su prohibición.

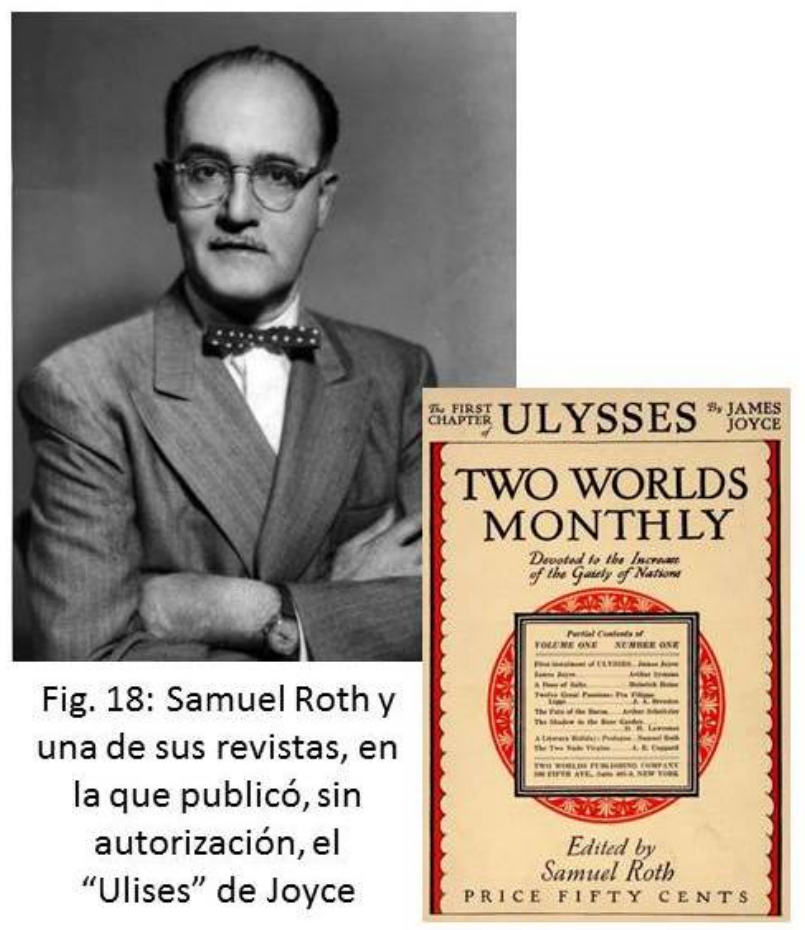

$\mathrm{Si}$ esta circunstancia traería consigo la lógica consecuencia de limitar hasta extremos intolerables las lecturas permitidas, la situación se agravaría más aún teniendo presente que el Hicklin test no exigía que la obra en su totalidad fuese obscena: bastaba con que parte de sus pasajes pudiesen reputarse como tales (por su capacidad para depravar a un lector inmaduro) para que la totalidad de la obra resultase vedada.

De todo lo dicho puede desprenderse que el test elaborado por el juez Cockburn adolecía de una patente ambigüedad, a la par que habilitaba a restringir excesivamente las publicaciones por incurrir en obscenidad. Percatándose de estos problemas, la jurisprudencia fue evolucionando hacia posturas más "libertarias", término que se empleaba para designar a los partidarios de una interpretación lata de la primera enmienda. En este proceso, los tres elementos ya citados del Hicklin test fueron reformulándose en una tortuosa singladura jurisprudencial.

Puesto que en el Hicklin test una publicación se calificaba como obscena por su tendencia a depravar o corromper, a finales de los años cuarenta los tribunales se plantearon la idoneidad de incorporar el test de "clear and present danger"; de este modo, sólo cuando hubiese un peligro claro e inminente de que esa depravación se produjese cabría reputar de obscena una publicación (Commonwealth v. Gordon, 66 D.\& C. 101, 1949; United States v. Roth, 237 F 2d, 1956). Esta idea -deudora de las posturas "libertarias" que pretendian que sólo podia prohibirse una lectura si se demostraba perjudicial ${ }^{203}$ - habría permitido desde luego limitar el alcance del Hicklin test, obligando a que la decisión judicial tuviese en cuenta si existía un peligro real de corrupción que justificase prohibir la obra cuestionada. Ello no obstante, en seguida se abandonó esta línea debido a la implantación de un nuevo test que vendria a sustituir al que había elaborado el juez Cockburn y que, a la postre, superaría algunas de sus deficiencias.

El asunto en cuestión que dio lugar a este nuevo test surgió a raíz de una demanda por publicaciones obscenas interpuesta contra Samuel Roth

${ }^{203}$ Murphy, Terrence J., Censorship: Government and Obscenity, op. cit., p. 104. 
quien, recordemos, habia comparecido ante el Special Subcommittee on Juvenile Delinquency del Senado, aunque se había negado a declarar precisamente acudiendo a la Quinta Enmienda, y por tanto a su derecho a no autoincriminarse por hallarse en curso de un proceso penal; precisamente el proceso que culminaria en la sentencia que ahora nos interesa. Samuel Roth era todo un personaje ${ }^{204}$. Nacido de una familia judia de ascendencia austríaca y polaca, vivió en sus carnes el antisemitismo que empezaba a imperar en Europa, hasta que emigró con su familia a New York en 1897, cuando apenas contaba con nueve años de edad. Inclinado desde joven hacia la literatura, en 1917 publicó su primer libro de poesía, y apenas dos años más tarde vería la luz un segundo. Durante su fugaz etapa como estudiante en la Universidad de Columbia -apenas un año- acometió por vez primera un cometido de editor, publicando una revista literaria. Pero fue en 1926 cuando esta vocación eclosionó realmente, con la publicación de varias revistas, como Two Worlds Quarterly, Two World Monthly y Casanova Jr.'s Tales. Aunque esta última, tal y como anunciaba su título, ya desarrollaba una temática en la que el sexo se hallaba bien presente, fue en otra revista creada ese mismo año, Beau, donde puso toda la carne en el asador, abordando temas tan conflictivos en la época como la homosexualidad o el aborto, lo que le valió su primer encontronazo con John S. Sumner, el sucesor de Anthony Comstock al frente de la New York Society for the Suppresion of Vice. A partir de entonces su vida se convirtió en casi una continua visita a juzgados $\mathrm{y}$, lo que es peor, a centros penitenciarios. Tan desafortunada carrera comenzó en 1928, cuando fue condenado a tres meses por poseer, con intención de vender, una versión ilustrada de la traducción al inglés del clásico texto erótico árabe "El jardín perfumado". Apenas dos años antes, había mostrado una nula falta de escrúpulos al publicar de forma seriada y sin autorización alguna el Ulysses de James Joyce, aprovechándose de la circunstancia de que los agentes de aduanas estadounidenses habian prohibido la entrada de la obra en el país, por obscenidad, y, de resultas, se negaban los derechos de propiedad intelectual al autor ${ }^{205}$. Aunque el autor irlandés no fue el único perjudicado; la afición de Roth por el plagio tuvo también como víctima al poeta Thomas Stearns Eliot, de quien publicó sin permiso varios poemas en el primer número de la revista Beau, considerada por otra parte una de las primeras "revistas para hombres" y precursora de Esquire.

En los años sucesivos, Roth dirigió una empresa dedicada a vender por correo un extenso volumen de revistas, libros y fotografias de cariz erótico, material que previamente publicitaba también por via postal, tras hacerse con los datos de correo de los potenciales compradores. Una práctica, dicho sea de paso, que también fue examinada por el Special Subcommittee on Juvenile Delinquency del Senado. En 1955, Roth fue arrestado por nada menos que veintiséis cargos por uso del servicio postal con fines obscenos. Tras hallarlo culpable un jurado, el asunto acabó en manos del Tribunal

204 Para una biografia de Roth véase Gertzman, Jay A.: Samuel Roth, Infamous Modernist, University Press of Florida, Gainesville, 2015, a quien sigo en este punto.

205 Birmingham, Kevin: The Most Dangerous Book. The Battle for James Joyce's Ulysses, The Penguin Press, London, 2014, p. 120-122; Spoo, Robert: Without Copyrights. Piracy, Publishing, and the Public Domain, Oxford University Press, New York, 2013, pp. 193-231. 
Supremo, que resolvió su caso de forma cumulativa con otro asunto (Alberts $v$. California), surgido a raíz de una sentencia de un Tribunal Municipal de California que había condenado por violación del Código Penal de aquel Estado al empresario David S. Alberts, quien se dedicaba como Samuel Roth a vender y publicitar publicaciones eróticas en su sede de Bervelly Hills ${ }^{206}$.

En la sentencia Roth $v$. United States (354, U.S. 476, 1957), el Tribunal Supremo asumió de forma incontestable que la obscenidad no formaba parte de la libertad de expresión constitucionalmente protegida, de modo que podía prohibirse lícitamente:

\begin{abstract}
"Se ha observado con acierto que [las obscenidades] no son una parte esencial de ninguna exposición de ideas, y poseen un valor social tan escaso para la obtención de la verdad que cualquier beneficio de pudiera derivarse de ellas se encuentra claramente compensado por el interés social en mantener el orden y la moralidad".
\end{abstract}

En este punto, se alteraba lo que se habia afirmado en Winters $v$. New York, (y posteriormente en Joseph Burstyn, Inc. v. Wilson, 343 US. 495, 1952) ${ }^{207}$ ya que ahora el Tribunal Supremo volvía a vincular libertad de expresión con "exposición de ideas", algo que en aquella otra sentencia había descartado. Pero, además, al considerar que una publicación obscena no constituía ejercicio de la libertad de expresión, el test de "clear and present danger” devenía innecesario. Éste servía precisamente para ponderar cuándo la libertad de expresión se estaba limitando correctamente (en concreto, cuando se apreciase la existencia de un peligro claro e inminente que hiciera preciso ese límite). Ahora bien, si una publicación obscena no era, por su

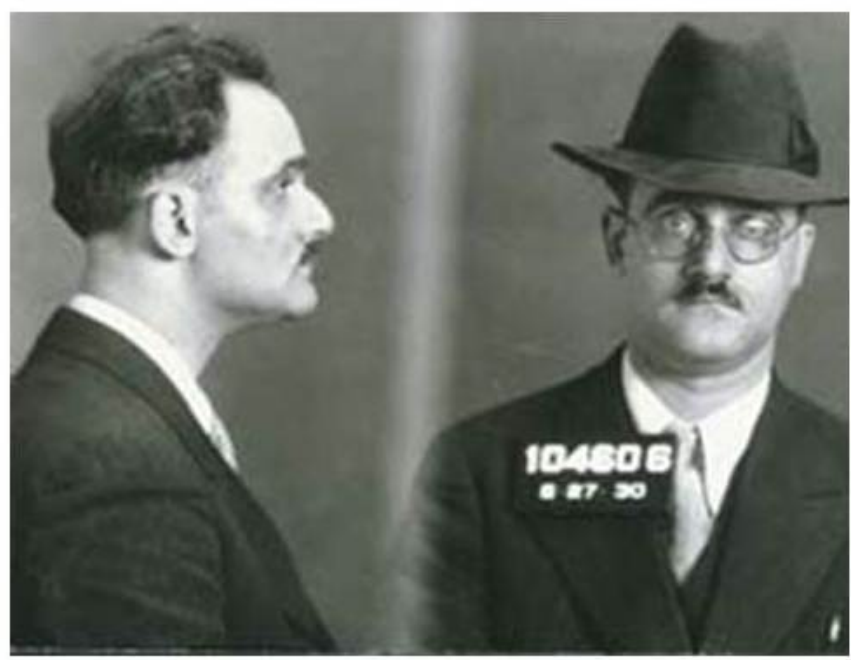

Fig. 19: Ficha policial de Samuel Roth naturaleza, ejercicio de la libertad de expresión, castigarla no suponía restringir la libertad de prensa y, de resultas, tampoco era preciso atestiguar que existía peligro alguno. Donde había obscenidad no habia libertad de expresión, y punto.

Aclarados estos extremos, Roth $v$. United States resultaria una sentencia clave por superar el Hicklin test, poniendo fin asi a un instrumento jurisprudencial que había prolongado su vida desde finales del siglo $\mathrm{XIX}^{208}$. El

206 Hixson, Richard F.: Pornography and the Justices. The Supreme Court and the Intractable Obscenity Problem, Southern Illinois University Press, Carbondale, 1996, p. 24.

207 Johnston, Gail: "Crime Comics and the Constitution", Stanford Law Review, vol. 7, núm. 2, 1955, p. 239.

208 Un extraordinario y detallado análisis de este cambio jurisprudencial puede consultarse en Strub, Whitney: Obscenity Rules. Roth $v$. United States and the Long Struggle over Sexual Expression, University Press of Kansas, 2013, pp. 138-182, asi como en Lockhart, William B. / McClure, Robert C.: "Censorship of Obscenity: The Developing Constitutional Standards", Minnesota Law Review, vol. 45, núm. 1, 1960, pp. 47 y ss. 
nuevo parámetro basaría la declaración de obscenidad en determinar "si para una persona normal (average), empleando los estándares contemporáneos de la comunidad, el tema dominante [de la publicación] tomado en su conjunto atiende a un interés lascivo"209. Se trataba por tanto de un nuevo test con algunos precedentes ${ }^{210}$ y que en los años 70 vendría a concretarse $^{211}$. En realidad esta perspectiva se aproximaba mucho a la propuesta de definición de obscenidad que habia elaborado el American Law Institute con un modelo de Código Penal diseñado en 1957, y conforme al cual una publicación sería obscena si, considerada en su totalidad, su sentido predominante fuese un interés lascivo (p. ej. un interés mórbido en desnudo, sexo o excreción) y llegase sustancialmente más allá de los límites habituales de candor en la descripción o representación de esa materia ${ }^{212}$.

El nuevo planteamiento del Tribunal Supremo echaba por tierra los tres elementos sobre los que se había construido el Hickin test. En primer lugar, la "tendencia a depravar o corromper" en la que se basaba la definición de obscenidad del Hicklin test quedaba sustituida por el "interés lascivo" que debía tener para asumir aquella condición ${ }^{213}$. De resultas, ya no se trataba de evaluar un efecto (la depravación), sino de intentar evaluar la intención de quien elaboraba la obra de promover la lascivia. Que depravase o denigrase moralmente ya no resultaba determinante; lo verdaderamente relevante era que la obra fuese concebida con un propósito erótico. De esta forma, resultaba fácil excluir de su campo de acción a obras de interés científico algo por otra parte ya adelantado en United States $v$. Dennet (39 F. 2d 564, 1930)-, pero también a obras literarias que no habian sido concebidas con un propósito libidinoso. En este sentido, devenía irrelevante que una obra científica o literaria (no concebida con propósitos eróticos) pudiese excitar sexualmente a determinados lectores. Bien podia ser así, y seguramente más de uno leería con ese propósito las detalladas estadísticas de los informes Kinsey, pero no por ello debían calificarse como obscenas, ya que su propósito no era el de provocar ese tipo de reacciones.

209 Véase también el voto concurrente del Magistrado Frankfurter en el caso Smith v. California (361 U.S. 147, 1959) donde urgía al Tribunal Supremo a aclarar jurisprudencialmente el concepto de obscenidad ajustado a los "estándares comunitarios contemporáneos".

210 Algunas de fechas tempranas, como United States v. Kennerley $(209$ Fed. 119, 1913), en la que el juez Hand señaló que podía ser tolerable utilizar como estándar la consciencia media del momento, pero no la mentalidad de las personas más inmaduras. Clor, Harry M., Obscenity and Public Morality. Censorship in a Liberal Society, op. cit., p. 19.

211 Millar $v$. California (413 U.S. 15, 1973), donde se fija un test de tres partes que permitiría determinar cuándo una publicación es obscena. Para ello, debería comprobarse si: (1) una persona media (average), de conformidad con los estándares contemporáneos de la comunidad, encontraría esa obra, tomada en su conjunto, como referida a un interés sexual lascivo; (2) la obra representa o describe de un modo claramente ofensivo, conducta sexual específicamente definida por la legislación aplicable; y (3) el trabajo, tomado en su conjunto, carece de un serio valor literario, artístico, politico o científico".

212 Paul, James C. N. / Schwartz, Murray L., Federal censorship. Obscenity in the mail, op. cit., p. 231.

213 En sentencias posteriores ni siquiera este "interés lascivo" resultaba suficiente, exigiéndose también un "patente carácter ofensivo". Manual Enterprises, Inc. v. Day (270 US 478, 1961). Clor, Harry M., Obscenity and Public Morality. Censorship in a Liberal Society, op. cit., p. 62 . 
El segundo elemento del Hicklin test que se superaba era el referido al sujeto que habria que tomar en consideración para evaluar la hipotética obscenidad de una obra. Ya no serian los menores de edad ni los sujetos fácilmente influenciables, sino, por el contrario, una "average person". Ciertamente, la definición de lo que debía entenderse por tal resultaba compleja ${ }^{214}$. De hecho, el asunto ya se había planteado a raíz de la prohibición de importación del Ulysses de Joyce. El Tribunal Supremo utilizó entonces la idea de "average person" -adelantándose en más de una veintena de años a Roth $v$. United States- frente al uso de "personas inmaduras" como parámetro para enjuiciar la obscenidad. Y en aquel entonces, el magistrado Martin T. Manton emitió un voto disidente en el que se quejaba de que la "average person" en la que parecía pensar el Tribunal Supremo no era ni tan siquiera una persona con una educación "estándar", sino mucho más: se trataba de una persona ampliamente cultivada y con una evidente experiencia literaria, de modo que se había basculado de un extremo a otro $^{215}$.

A pesar de la indefinición de qué debía entenderse por "average person" y, por tanto, del sujeto por el cual se calibraba la obscenidad o no de una obra, existian un par de factores que permitian un atisbo de concreción. En primer lugar, el concepto podía definirse siquiera de forma negativa: la "average person" no se identificaba ni con menores de edad ni con personas mentalmente influenciables. Se trataba, pues, de un sujeto mentalmente más capacitado, lo cual permitía elevar los estándares de la obscenidad. Y es que una cosa es que los menores debiesen siempre ser objeto de protección pública (Prince v. Massachussets, 321 U.S. 158, 1944) y otra cosa bien distinta es que, con el fin de tutelarlos, se acabase por vedar a los adultos el acceso a determinadas lecturas, en cuyo caso la medida resultaba manifiestamente desproporcionada (Butler v. Michigan, 352 U.S. 380, 1957)216.

Un segundo factor que permitía concretar hasta cierto punto la idea de "average person" era la referencia a los "estándares contemporáneos de la comunidad" que, aplicados a ese sujeto, debian ser lo que determinasen la lascivia de la publicación. Con tal mención, se tomaban como referencia los valores sociales de cada momento, lo cual permitía una constante adaptación de los estándares que el juez debía tomar en consideración para determinar si una publicación resultaba obscena. Ya no se trataba, pues, de que el juez interpretase si una obra podía perjudicar a una mente inmadura; con la nueva jurisprudencia, el juez tenía que examinar el grado de tolerancia social hacia el erotismo, poniéndose en el lugar de un adulto común

214 Los problemas de esta definición, en Lockhart, William B. / McClure, Robert C.: "Censorship of Obscenity: The Developing Constitutional Standards", Minnesota Law Review, vol. 45, núm. 1, 1960, p. 70.

215 Murphy, Terrence J., Censorship: Government and Obscenity, op. cit., p. 46.

216 Esta jurisprudencia fue confirmada en las décadas de los ochenta y noventa por casos como el Bolger v. Youngs Drug Productions Corp. (463, U.S. 60, 1983) y Reno v. American Civil Liberty Union (521, U.S. 844, 1997). La idea anterior, a la que daba respaldo el "Hicklin test" partía de la idea victoriana de que existian determinadas obras -las obscenasque nadie debería poder leer, ni tan siquiera los adultos. Paul, James C. N. / Schwartz, Murray L.: "Obscenity in the Mails: A Comment On Some Problems Of Federal Censorship", University of Pennsylvania Law Review, vol. 106, núm. 2, 1957, pp. 223 у 239. 
(“average peson"). De este modo, a mayor puritanismo social corresponderia un menor margen de admisión hacia lo potencialmente obsceno; y a mayor liberalidad, la situación se revertiria. Aun así, cabe mencionar que este nuevo criterio arrojaba alguna nueva duda: los estándares comunitarios, ¿se referian a los valores de la comunidad local o, por el contrario a nivel nacional?217 Como si de la mitica Hidra se tratase, cada vez que se solucionaba un problema otros dos parecian emerger en su lugar.

Debe tenerse presente que en este punto, el Roth test prescindia de un aspecto relevante, cual era el público al que se dirigía la publicación en concreto. En este sentido, no se diferenciaba de lo que habia configurado el Hicklin test: este último también prescindia del sujeto al que iba destinada la publicación. El resultado es que para el Hicklin test parecía como si todas las obras fuesen leídas por niños, en tanto que para el Roth test-con el empleo de la figura de "average person"- daba la sensación de que sólo los adultos leían en el país. De esta circunstancia se percató la doctrina, que propuso que en vez de utilizar como parámetro un tipo de sujeto en abstracto (el inmaduro, en el Hicklin test, el adulto normal, en el Roth test) se atendiese a la "audiencia probable". Si una obra iba dirigida sustancialmente a adultos, la mentalidad de estos debía ser el parámetro para mensurar la obscenidad; si tenía como destinatario a menores de edad, la psique de ellos debía ser la que se tomase en consideración ${ }^{218}$

El último de los elementos propios del "Hicklin test" que se superaron merced a Roth $v$. United States fue el referido a la posibilidad de declarar una obra obscena sólo por contener algunos pasajes inadecuados. Esta circunstancia permitía que una obra resultase prohibida a pesar de que apenas algunos pocos fragmentos resultasen cuestionables. Esta perspectiva empezó a superarse tímidamente en algunas sentencias de principios del siglo XX, como en United States $v$. Kennerley (209 F. 119, 1913), en la que se afirmaba que un libro no debía declararse obsceno cuando los pasajes inadecuados resultasen auxiliares de ideas inocentes y en su conjunto la obra no tuviese la condición de obscena. Posteriormente, en la ya citada sentencia referida al "Ulysses" de James Joyce se reafirmó esta idea con mayor claridad. El Tribunal Supremo estimó entonces que era necesario tomar en consideración el conjunto de la obra, consolidando la teoría que se denominaria del "efecto dominante". Si, por el contrario, se tomasen sólo fragmentos como referencia para juzgar la obscenidad-como sucedía con el "Hicklin test"- el resultado sería que el escritor se sentiria tentado a eliminar de su obra cualquier pasaje de índole sexual a fin de evitar la declaración de obscenidad; pero con ello se estaría falseando la vida misma, porque la sexualidad formaba parte de ella, convirtiendo las narraciones en productos irreales en cuanto asexuados.

Esta tendencia a tener presente la totalidad de la obra, y no fragmentos de la misma, volvió a reiterarse en una sentencia que se convertiría en

217 Por ejemplo, a favor de un estándar comunitario nacional: Manual Enterprises, Inc. $v$. Day (270 US 478, 1961).

218 Lockhart, William B. / McClure, Robert C.: "Obscenity in the Courts", Law and Contemporary Problems, vol. 20, núm. 4, 1955, p. 601; Johnston, Gail: "Crime Comics and the Constitution", Stanford Law Review, vol. 7, núm. 2, 1955, p. 241. 
referente, emanada por una demanda de obscenidad contra la revista Esquire. En Tribunal Supremo, enjuiciando el poder censor del "Postmaster General" concluía que sólo una parte de los números de Junio a Noviembre de 1943 (que eran los cuestionados) resultaba cuestionable, puesto que la mayoria de los textos contenían artículos de interés, recensiones de libros o historias inocuas (Hannegan v. Esquire Inc., 327 U.S. 146, 1946). Esta perspectiva de tomar la obra en su conjunto quedaria ya plenamente incorporada en el nuevo test impuesto por Roth $v$. United States al ponderar la obscenidad de la publicación "tomada en su conjunto".

Este acervo jurisprudencial sobre la obscenidad hasta aquí examinado resultaba en términos generales beneficioso para los partidarios de los cómics. En primer lugar, para prohibir un cómic resultaba preciso demostrar que su tema dominante atendiese a un "interés lascivo". Cierto es que quizás este elemento era el que mejor podía emplearse contra los cómics: a fin de cuentas no parecía un despropósito deducir que los desfiles de lencería que se veían en numerosas viñetas, las ropas femeninas rasgadas, la presencia de imágenes que evocaban bondage o sadismo, o la exageración de los atributos femeninos, todo ello servía a un propósito lascivo a menudo orquestado por editores como Victor Fox. Aun así, esa tendencia erótica, palmaria en géneros como los headlight comics, no resultaba tan evidente en otros casos.

Pero aunque se percibiera ese interés lascivo, los otros elementos incorporados por la sentencia Roth $v$. United States si que beneficiaban a los cómics. Y es que, ese interés lascivo ya no tenía que mensurarse a partir de la psique del menor, sino de lo que opinaria una persona media ("average person"), según los estándares comunitarios en relación con el tema de la sexualidad. El listón, por tanto, se elevaba, porque ya no era una mente inmadura -y por lo tanto más fácilmente influenciable- lo que se utilizaba para calibrar la existencia de obscenidad. Y, sobre todo, el último de los elementos que incorporaba el nuevo test venía muy bien para la defensa de los cómics: ese interés lascivo (según lo considerase una "average person" a partir de los estándares comunitarios) debía predicarse de la publicación "en su conjunto". Esta idea se había forjado, como vimos, en casos en los que se estaba juzgando la obscenidad de un libro -como el Ulysses-, y alli tenía pleno sentido. Pero la sentencia Hannegan $v$. Esquire también la había validado para las revistas y eso era, desde luego, un punto muy favorable para los cómics. La presencia de viñetas inadecuadas, o incluso de historietas enteras dentro de un comic book donde habia otras inocuas, impedía la consideración de la revista como obscena. Algo criticado por un sector doctrinal, que tampoco consideraba que este criterio fuese muy adecuado cuando se trataba de enjuiciar publicaciones dirigidas a menores de edad, ya que en ellas una sola imagen podía tener efectos nocivos ${ }^{219}$.

La jurisprudencia en materia de obscenidad también protegió a los vendedores de cómics, que a la postre resultaban el eslabón más débil de la cadena. Puesto que la normativa antiobscenidad aprobada a nivel estatal y municipal tenía carácter penal, a finales de los años cincuenta empezó a exigirse la existencia de intencionalidad (scienter) en la venta de material

219 Murphy, Terrence J., Censorship: Government and Obscenity, op. cit., p. 68. 
obsceno. Este argumento sirvió al Tribunal para declarar inconstitucional parte del Código Municipal de Los Ángeles que declaraba punible la posesión de material obsceno en comercios que dispensaran productos consumidos por menores (Smith $v$. California, 361 U.S. 147, 1959). Puesto que al comerciante, en este caso concreto un librero, le resultaba imposible conocer el contenido de todo el material que vendía, no podía apreciarse intencionalidad y, de resultas, tampoco responsabilidad penal ${ }^{220}$.

Toda esta jurisprudencia hasta ahora citada sirvió para contener dentro de la libertad de prensa y del due process of law la legislación represiva de los Estados contra los cómics. Cerradas las vías de una censura previa -según vimos anteriormente- y los intentos de criminalizar sin más tanto el medio de expresión en sí mismo como su distribución, el Tribunal admitió en fecha ya muy tardía una única posibilidad: impedir la venta de cómics de contenido inadecuado a menores de edad (Ginsberg v. New York, 390 U.S. 629, 1968). De este modo, no se le exigia al comerciante conocer todo el material de que disponía, sino simplemente no dispensarlo a menores de edad cuando su contenido fuese manifiestamente obsceno, comprobación que podía realizarse, con cierta facilidad, en el momento mismo de la transacción. Así pues, lo que se sancionaba no era la tenencia de cómics obscenos (algo que requeriría una supervisión previa por el comerciante de todo el material de su negocio), sino la venta de estos, ya que en ese instante el vendedor debía verificar si lo que ponía en manos del menor de edad era material apto para su consumo.
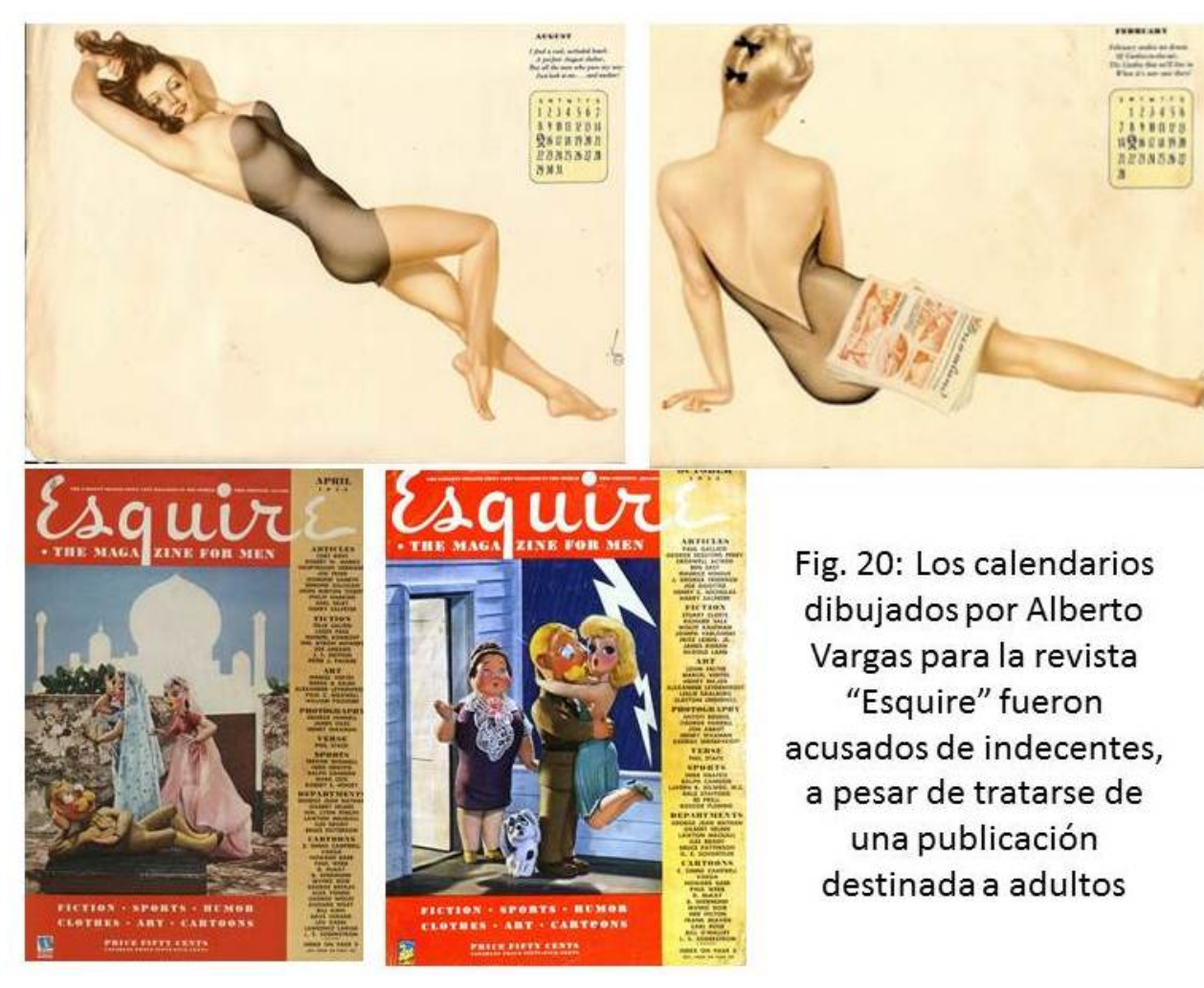
Fig. 20: Los calendarios dibujados por Alberto Vargas para la revista "Esquire" fueron acusados de indecentes, a pesar de tratarse de una publicación destinada a adultos

220 Tampoco admitía el Tribunal la posibilidad de que el librero pusiese a la venta exclusivamente aquel material que hubiera comprobado con anterioridad, ya que en ese supuesto se reduciria el volumen de obras que estaría en condiciones de vender, lo cual acabaría afectando el derecho de los ciudadanos a acceder a las lecturas. Es evidente que este argumento ponía el acento en la vertiente de la primera enmienda como "derecho de acceso a la lectura", que ya he mencionado con anterioridad. 
Los jueces habían dificultado pues cualquier intento de criminalizar las publicaciones que la campaña antivicio reputaba inmorales. Ni la legislación antiobscenidad ni las leyes especificamente creadas contra las publicaciones sobre crímenes lo tendrian fácil en lo sucesivo para superar el test de constitucionalidad. Por supuesto quedaría mucho camino aun por recorrer. Tras las dime novels, pulp magazines, comic books y booklets, llegarian las revistas de explícito contenido pornográfico, como Hustler, a las que la relajación jurisprudencial en materia de obscenidad no parecía aplicárseles. Pero al menos se habian fijado limites infranqueables a las cruzadas morales. Ya no todo lo que les disgustaba podía ser objeto de persecución penal. Sólo el material más explícitamente pornográfico quedaba sujeto a cautelas. Era un primer avance hacia una liberalización plena de la literatura, que admitiese que los adultos pueden escoger sus lecturas. Lo que no es poco.

Fecha de envío / Submission date: 23/03/2018

Fecha de aceptación / Acceptance date: 25/04/2018 